\title{
Concerned yet polluters: A survey on French research personnel and climate change
}

\author{
Marianne Blanchard ${ }^{1,2}$, Milan Bouchet-Valat ${ }^{2}$, Damien Cartron ${ }^{3}$, Jérôme Greffion ${ }^{4}$, Julien Gros ${ }^{5}$
}

1. CERTOP, Université de Toulouse - Jean Jaurès, Toulouse, France

2. Institut national d'études démographiques (INED), Aubervilliers, France

3. $\mathrm{CMH}, \mathrm{CNRS}$, Paris, France

4. IDHES, Université Paris Nanterre, Nanterre, France

5. LEST, CNRS, Aix-en-Provence, France

\begin{abstract}
:
We present a survey on the French research community and climate change carried out in 2020. It is one of the largest surveys ever conducted on this issue: it is based on a sample of more than 6,000 respondents representative of the French public sector research community, regardless of their status and discipline. On the one hand, it measures practices that emit large amounts of greenhouse gases, such as air travel, and addresses the differences between disciplines and within them according to different individual characteristics (gender, status, location, etc.). On the other hand, it questions the representations of research actors concerning the climate emergency, and what they are willing to do to reduce their emissions.

The survey highlights three results: first, an acute awareness of environmental and climate issues widely shared by members of the scientific community; second, a willingness to implement changes; and third, a clear gap between these attitudes and practices that still emit large amounts of greenhouse gases. This raises the question of the role of research institutions, whose support is required to implement profound reforms in the organization of research activities.
\end{abstract}

Keywords: climate change; research; survey; flying; IT equipment; ecology 


\section{Introduction}

For several decades, researchers have highlighted the role played by human activities in greenhouse gas emissions and their effects on climate change. With the academic community working more than ever on these issues, researchers from several countries have in the last few years been investigating the environmental impact of their own occupational activities. These initiatives were initially led by climate and environmental scientists, underscoring the seeming paradox [1], or even hypocrisy [2], of polluting as part of their research while insisting that the population change its behaviour. Several studies have demonstrated that scientists emit more greenhouse gases (GHGs) than the average citizen [3,4], notably owing to their frequent use of air travel.

Climate and environmental researchers stand apart from other researchers as their credibility and ability to raise awareness of the urgency of reducing GHG emissions might hinge on their own behaviour [5]. But researchers in other disciplines are also paying increasing attention to the impact of their occupational activities ([6] in geography, [7] in astronomy, [8] in the history of transport).

As more such initiatives are rolled out, a better understanding is being forged of the actual impact of research activities on GHG emissions. But much remains to explore concerning differences between disciplines, and within the same discipline, stemming from individual characteristics (such as sex, status, and location), which is essential for implementing appropriate and effective changes. In addition, research on how research personnel perceive climate urgency, and what they are willing to do to reduce their emissions, is thin on the ground. In short, knowledge is lacking on the practices and characteristics of the groups with the highest GHG emissions, and on their perceptions, including their opinions on and understanding of climate issues and the reforms they deem acceptable or unacceptable.

The survey "Research personnel and climate change" we present here seeks to shed light on these grey areas. Conducted in 2020, it addresses practices before 2020 (pre-COVID) as well as perceptions. It is based on a large sample of over 6,000 respondents representative of French research personnel, regardless of their status or discipline (covering more than 70 disciplines). This article introduces the main themes and the initial results. Following a review of the literature, we present the survey questionnaire, the protocol, and the response rates obtained. We then focus on a few fundamental findings of the collected data concerning the opinions of research personnel on climate change, their GHG emissions, and the solutions that they are willing to implement to reduce those emissions.

\section{State of the literature and contributions of the survey}

For a little over a decade, a growing number of members of the academic community have explored the environmental impact of their research activities, from the standpoint of individuals [9], research programmes [10,11], and institutions [12,13].

While some works have addressed issues such as waste management, and in particular the pollution generated by plastic waste in laboratories [14,15], or, more globally, the concept of 'green campuses' [16], in this article we focus on the GHG emissions stemming from research activities and the effect of the latter on climate change.

Despite the growing interest in these issues, resulting from increasing awareness of the risks and the mounting urgency of taking action, the research published thus far provides what remains a fragmented review of the practices and perceptions of researchers. 


\section{Literature focused on air travel}

Almost all the studies on the environmental impact of research concern the use of air travel $[4,8,17]$. This is justified by the fact that flights generate a large share of the GHG emissions of research activity. The University of British Columbia in Canada has estimated that flights account for $63 \%$ to $73 \%$ of total emissions [18]. At École Polytechnique Fédérale de Lausanne (EPFL), air travel accounts for one-third of total GHG emissions, equivalent to all the emissions generated by electricity consumption, heating, and commuting [12].

Many publications focus on the carbon impact of conferences [19], one of the main reasons for air travel. The GHG emissions generated by air travel range considerably, from $500 \mathrm{~kg} \mathrm{CO} \mathrm{C}_{2} \mathrm{e}$ per participant [20] to $950 \mathrm{~kg} \mathrm{CO} 2 \mathrm{e}$ [21,22]. To put this into context, the European Commission objective to reduce emissions by $55 \%$ by 2030 relative to 1990 corresponds to $2.1 \mathrm{t}$ $\mathrm{CO}_{2} \mathrm{e} /$ year/inhabitant [23].

Solutions have been proposed [24] to reduce emissions, such as organizing fewer conferences, optimizing venue access, implementing regional hubs hosting participants at the same time, and increasing the use of videoconferencing.

But the emphasis placed on air travel should not obscure other sources of the GHG emissions generated by research, including IT equipment, commuting, the use of office space, catering (canteens and food stands), heating, the consumption of electricity (lighting, power for machines), and digital technology $[25,26]$. In some disciplines, scientific equipment stands as a major source of emissions, for example in astronomy [7], with its energy-intensive supercomputers.

While we have devoted considerable attention to the use of air travel in our survey, notably through a special bloc of questions (see next section), we have also addressed other GHGemitting practices, such as commuting and the use of experimental equipment and IT equipment, for which it appears possible to initiate discussions and short-term actions.

\section{The contributions of a large-scale survey}

Literature review shows that most existing research is limited to specific populations, be they members of the same institution [12,27,28], discipline [3,7], department [29], or working group [11]. The homogeneity of the population studied in these cases prevents taking simultaneous account of characteristics such as status, discipline, or geographical location to measure their impact on GHG-emitting practices. Furthermore, the sample sizes are often modest.

Exceptions exist, among them a study conducted in 2017 with 1,400 scientists from a range of disciplines in several countries [30], which demonstrated that climatologists often fly more than their peers from other disciplines for occupational reasons but less for personal reasons.

The limited scope of most studies largely results from the conditions in which they are produced. Many of them are undertaken by researchers on the margins of their main research activities, as part of their own examination of their environmental impact, and/or in the context of a given institution, as a preliminary medium for implementing measures to reduce environmental impact. In short, few dedicated and wide-ranging research projects have focused on this issue.

To our knowledge, our survey is the largest ever to be conducted in terms of sample size (over 6,000 respondents) and scale, as it covers all types of status and disciplines in French research. It is also the sole sociological study of these questions and includes an array of variables for characterizing individuals, serving ultimately to understand - looking beyond discipline and status - variations in practices and opinions, as well as their determinants. Among other aspects, we take account of sex, age, seniority and career stage, occupational activity venue, number of children, living standard, awareness of environmental issues, and international aspects. 


\section{The interest of considering practices and opinions}

Some of the existing research is devoted solely to practices, notably the use of air travel. Several studies have drawn on the processing of data collected by the institution funding air travel (laboratories, universities, research consortiums) to quantify its GHG emissions [10,31]. While this approach serves to accurately measure travel, it is not always able to identify the reason for travel or to put into perspective the use of air travel and knowledge of and opinions on climate issues. More broadly, these studies do not help us to understand the meaning placed by individuals in their practices or their more general opinions on climate change and the necessity, or otherwise, of implementing change.

Research on the overall population suggests a weak link between knowledge of environmental issues and practices [32,33]. This result has been verified for researchers in the environment, economics, and health based on their personal practices (personal use of air travel, consumption of meat, etc.) [34].

\section{The questionnaire}

Our survey was designed as part of Labos 1point5, an interdisciplinary collective created in March 2019 bringing together research professionals with the objective goal of reducing the environmental footprint of research activities (https://labos1 point5.org/).

The survey questionnaire was disseminated online from June to December 2020, immediately after the first COVID-19 lockdown in France. To reduce any COVID-19 disruptions on occupational practices, the respondents were asked about their practices in 2019. The survey does not aim to describe changes in the world of research generated by the epidemic.

The survey is based on a questionnaire administered online using the LimeSurvey software. The aims of the questions are to:

1. Measure practices generating substantial GHG emissions, both individually and collectively (primarily transport, equipment, and energy consumption): understand their contexts and determinants, differentiate between uses according to their motives and the interest for the respondents, and identify changes in practices having already been made for environmental reasons.

2. Explore solutions and their acceptability: gather the opinions of research personnel on the transformations to be implemented in the world of research to reduce GHG emissions, based on their opinions on regulatory and organizational proposals and on reductions they deem possible at an individual level.

3. Gather the perceptions of research personnel on environmental issues, climate change and ecology in general, identify any occupational or personal commitments to ecology, and assess knowledge of GHG emissions generated by occupational practices.

4. Assess the occupational and personal situation of the respondents: identify the position of respondents in the scientific field and in their career (discipline, status, publications, funding, internationalization) and determine the social position of respondents and their household.

The questionnaire was designed to take a reasonable amount of time to complete, at around 30 minutes. To prevent excessive completion times, two sets of questions identified as more time-consuming and unlikely to be crossed in the same analysis (professional flights on the one hand, and commuting and IT equipment on the other) were put in modules. Each respondent had to answer only one of the two modules, drawn at random. To limit the risk of respondents stopping the survey at an early stage, it begins with more consensual questions on occupational activity, and ends with more potentially sensitive questions concerning 
personal aspects. The questions were organized into nine groups, overviewed below (for more details, see the English translation of the questionnaire in S3 Appendix).

\section{Position relative to the environment and research}

The aim with this group of questions is to quickly identify the position and mindset of the respondents relative to climate issues and their research practices. An initial series of questions serves to identify any potential climate skeptics and measure how concerned the respondents are about climate issues. A second set of questions concerns the respondent's position as a researcher, addressing aspects such as environment-linked research themes and having forgone research topics for ecological reasons.

\section{Individual and laboratory practices}

This section seeks to measure the efforts made collectively at laboratories and individually by respondents to shrink their carbon footprint. Some of the questions address daily behaviour (such as sorting waste, buying locally, and double-sided printing) that may admittedly have only a modest effect on emissions but indicates an initial engagement.

Further questions in this section address practices that generate more emissions, including the purchase and use of IT equipment, and the use, for the personnel concerned, of experimental equipment of varying size. A table aims to assess changes in emissions in different fields over the last five years.

\section{Transports in an occupational setting}

These questions aim to identify transport practices in two areas that we can expect to have a heavy impact on the GHG emissions of research personnel: air travel (see Appendix S2) and commuting. Owing to their length, the most detailed questions in this section are organized into two separate modules posed randomly to one respondent in two. The more general questions were posed to the entire sample.

Besides precisely measuring these polluting practices, the objective is to determine the underlying reasons, such as the subjective interest in conferences or congresses abroad and obstacles to favouring the use of trains and carpooling.

Since international conferences have become an increasingly important reason for air travel in the last few decades, we ask the respondents about what value they found in their last conference abroad. For those having forgone an international trip, we seek to identify the reasons, notably environmental.

Regarding commuting, the questionnaire serves to precisely review the transport modes and times of the interviewees and identify the extent of teleworking (in the pre-lockdown period).

\section{Use of videoconferencing}

The objective of this section is to estimate the use of videoconferencing and audioconferencing (and the reluctance of using these media) as well as the effect of the lockdown on these uses and how they are perceived. We notably seek to determine whether the respondents extended their use of videoconferencing after the lockdown.

To that end, we measure the degree of use (before and after the lockdown) and the diversity of use (meetings, conferences, juries, etc.), along with changes in the personal opinion of the 
respondents regarding videoconferencing. We aim to precisely determine any obstacles to extending the use of videoconferencing beyond lockdown situations.

\section{Concrete solutions in research}

This set of questions collects the opinions of respondents on solutions seen as possible and desirable for reducing GHG emissions. The questions concern individual changes (what the interviewee is willing to do) and collective changes.

\section{Personal opinions on ecology in general}

These questions aim to forge a deeper understanding of the respondents' positions on ecology in general, based among others on standard questions from the 'environmental attitudes inventory' [35], addressing how individuals feel about environmental risks, their commitment to environmental protection, their personal use of air travel, and global changes that they see as desirable or useful.

\section{Personal activity and situation}

Questions on key personal information (sex, age, status, discipline, etc.) are asked at the start of the questionnaire, other aspects being covered at the end. The questions concern variables likely to increase climate impact (particularly owing to travel), including access to extensive funding or an extremely international profile. The number of publications of the respondent, particularly in English, serves to test the existence of a relationship between the frequency of trips and the production of researchers.

Further questions help to measure the occupational situation of the respondent (career advancement, job situation, and whether the individual is at a strategic moment in their career, for example seeking a new position or promotion). Questions are asked on part-time work and sick leave to account for the fact that reduced working time likely corresponds to a reduction in GHG-emitting activities.

Questions are asked to specify the respondent's personal situation (socio-demographic variables, couple, children, income, education level of parents, etc.) with the assumption that opinions and behaviour depend in part on the socio-demographic characteristics of the individuals and on their socialization in their youth. A question on household income serves to determine living conditions and gauge whether the latter are related to occupational practices.

Lastly, information on the places of residence and work is collected to better understand commuting distances and measure differences in behaviour according to the type of area in which the individual works (Paris region, large city, average sized town). Only derived data are disseminated in the survey database (department, size of urban unit, part of the catchment area of a town, etc.).

\section{Quiz on GHG emissions}

This quiz was given on an optional basis to respondents having finished the rest of the questionnaire. The aim is to assess the respondent's understanding of how much emissions need to be reduced if we are to limit climate change and their perception of the largest sources of emissions. This information is important for testing the relationship between individual behaviour, the sense of climate urgency, and the perception of how much individual activities emit greenhouse gases. 


\title{
Sample and non-response bias
}

\author{
Building the sample: draw and reminders
}

The Centre National de la Recherche Scientifique (national scientific research centre, CNRS) is the largest public-research institution in France. Working alone or together with other institutions, such as universities, the CNRS coordinates the activity of over 1,100 research laboratories across the country. Our population includes all the employees of CNRS regardless of their activity (including technical and administrative staff), as well as researchers and professors from other institutions (universities, private and public research institutes, etc.), $\mathrm{PhD}$ students and postdoctoral researchers, and any other type of personnel who are members of these structures.

To build a representative sample of this population, we used the CNRS directory, Labintel, which includes the 130,000 people affiliated with a CNRS unit or service. In all, it covers around half of the 250,000 public-research employees listed in 2018 in France by the Ministry of Higher Education and Research (including part-time employees; authors calculations based on [36]).

In June 2020, 30,000 email addresses were drawn at random (simple random sample) and the address holders were sent a message at the end of June asking them to respond to the questionnaire, along with a unique access link. Out of the 30,000 addresses, $4.6 \%$ generated an error when the questionnaire invitation was sent. However, it is probable that a much higher proportion of the invitations was never received, as servers do not systematically issue an error message when an email is unable to be delivered, anti-spam filters may block messages, and some email accounts are not used (notably those of non-permanent personnel, whose addresses do not appear to be systematically withdrawn or updated when they leave or change status). The quality of the survey database varies according to the status of personnel. It is excellent for paid CNRS staff, good for regular staff not paid by the CNRS, and average for other personnel, notably PhD students.

Ultimately, 6,723 people, corresponding to $23.6 \%$ of the invitations sent without error, went beyond the homepage of the questionnaire and 6,469 people (or $22.7 \%$ of invitations) completed the first page of questions. This is a relatively high response rate for a selfcompleted online questionnaire. The result is all the more satisfying as the respondents were notified that the time required to fill in the questionnaire was fairly long (estimated at 15 to 20 minutes on the homepage). To convince the individuals drawn to respond, in our initial message we stressed how important their participation was to fully reflect the 'diversity of practices and opinions' and to 'find answers to environmental issues by reflecting the multiplicity of viewpoints', while at the same committing to the anonymity of responses. To fully guarantee future respondents of the serious nature of the survey, we also stressed our institutional affiliations (CNRS, universities), the structure in which the questionnaire was built (Labos 1point5), and the context in which the data would be processed (a CNRS-Inrae research network, GDR).

The response rate, quite low following the initial message (10\%), was improved by issuing four reminders to the people having failed to respond to the questionnaire, in July, September, October, and November. In those reminders, we reiterated the interest of the survey and reassured recipients that the message was not spam or a phishing attempt (first reminder). The third reminder proved particularly effective, the number of new responses being two and a half times higher than after the second reminder. This may be explained by the change in tone of the message, with less academic and more natural wording. The subject ('Survey on research and climate change: your participation counts!') and content ('We need you to top the mark of 5,000 respondents, ensure representativeness and reflect the diversity of practices and opinions') had been adjusted to attract the attention of the recipients, mention being made 
of a 'last-chance reminder' and a questionnaire that would 'soon be closed'. In addition, the email was no longer sent from an impersonal address associated with the collective (enquete@labos1point5.org), but from the institutional address of the sole woman in the design team. This personalization, and perhaps the female first name, may also have further encouraged the recipients to respond [37]. The last reminder, also more effective than the second, adopted a similar tone. Specific reminders for people having started but not finished the questionnaire were sent at the same frequency, with a supplementary reminder at the end of November.

The relevance of this series of reminders was reflected in the fact that most responses were obtained on the day that each message was sent (nearly $80 \%$ ), this trend having clearly accentuated over time.

Despite the long response time (median of 28 minutes and average of 40 minutes for those reaching the last page and excluding those having responded over several days), few respondents gave up along the way (15\%). The good response rate for a self-completed online questionnaire, along with the low abandon rate, likely reflect both an interest in the topic from research personnel and the successful design of the online questionnaire, which was tested on numerous people before the survey was publicly launched.

\section{Response rate by status and discipline}

The information available in the CNRS directory can be used to calculate the response rates, which vary according to status, discipline, and sex. We will focus here on the response to the first page of the questionnaire. Regarding status, researchers, research engineers and research support engineers stood apart with a response rate of $30 \%$ to $36 \%$, while just $17 \%$ of fully funded $\mathrm{PhD}$ students, $15 \%$ of technicians, and $17 \%$ of other personnel responded (Fig 1). The response rate of non-permanent personnel was probably under-estimated given that the information concerning them in the database is not always up to date.

These differences also applied in terms of discipline (approached by CNRS institutes), the response rate standing at $31 \%$ for personnel working in earth sciences, astronomy, and astrophysics, $26 \%$ to $28 \%$ for physics and ecology personnel, and $20 \%$ to $21 \%$ for personnel in the human and social sciences, chemistry, biology, and information and engineering sciences (Fig 2). Women responded slightly more than men (25\% and $22 \%)$, which can be attributed to their greater sensitivity to ecology [38]. The trends indicated here using raw percentages are confirmed when estimating a logistic regression controlling for these three variables and the region (see section 1.1 in S1 Appendix). 
Fig 1. Response rate to the first page of the questionnaire by respondent status

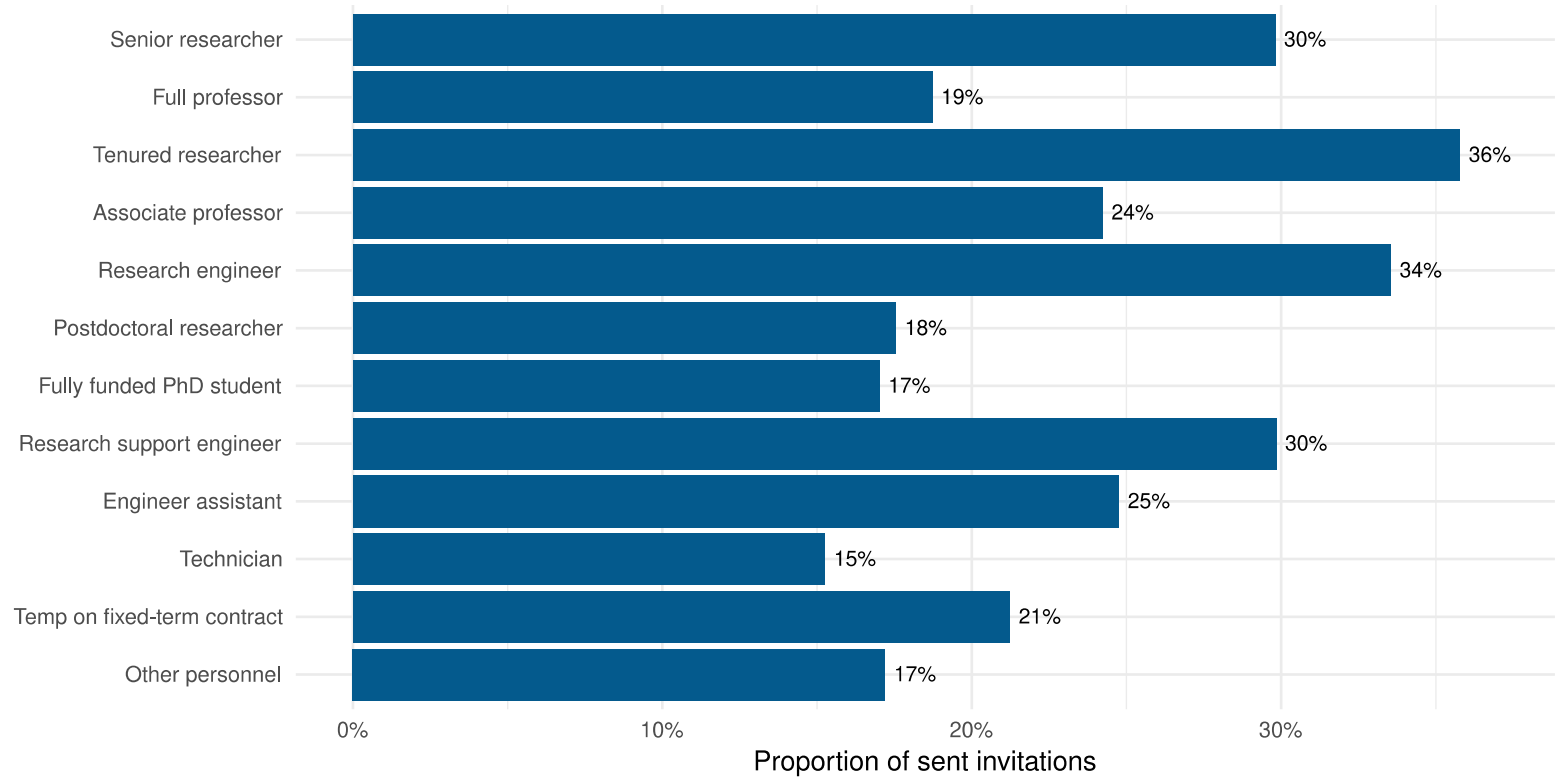

Several tenure statuses exist in France for personnel carrying out research at a public education and/or research institution. Researchers perform this activity on a full-time basis, while professors devote half of their working hours to teaching.

See S4 Appendix for the French version of statuses. The CNRS directory uses a slightly less precise set of statuses than the one used in the survey questionnaire.

Fig 2. Response rate to the first page of the questionnaire by respondents' disciplinary institute at CNRS

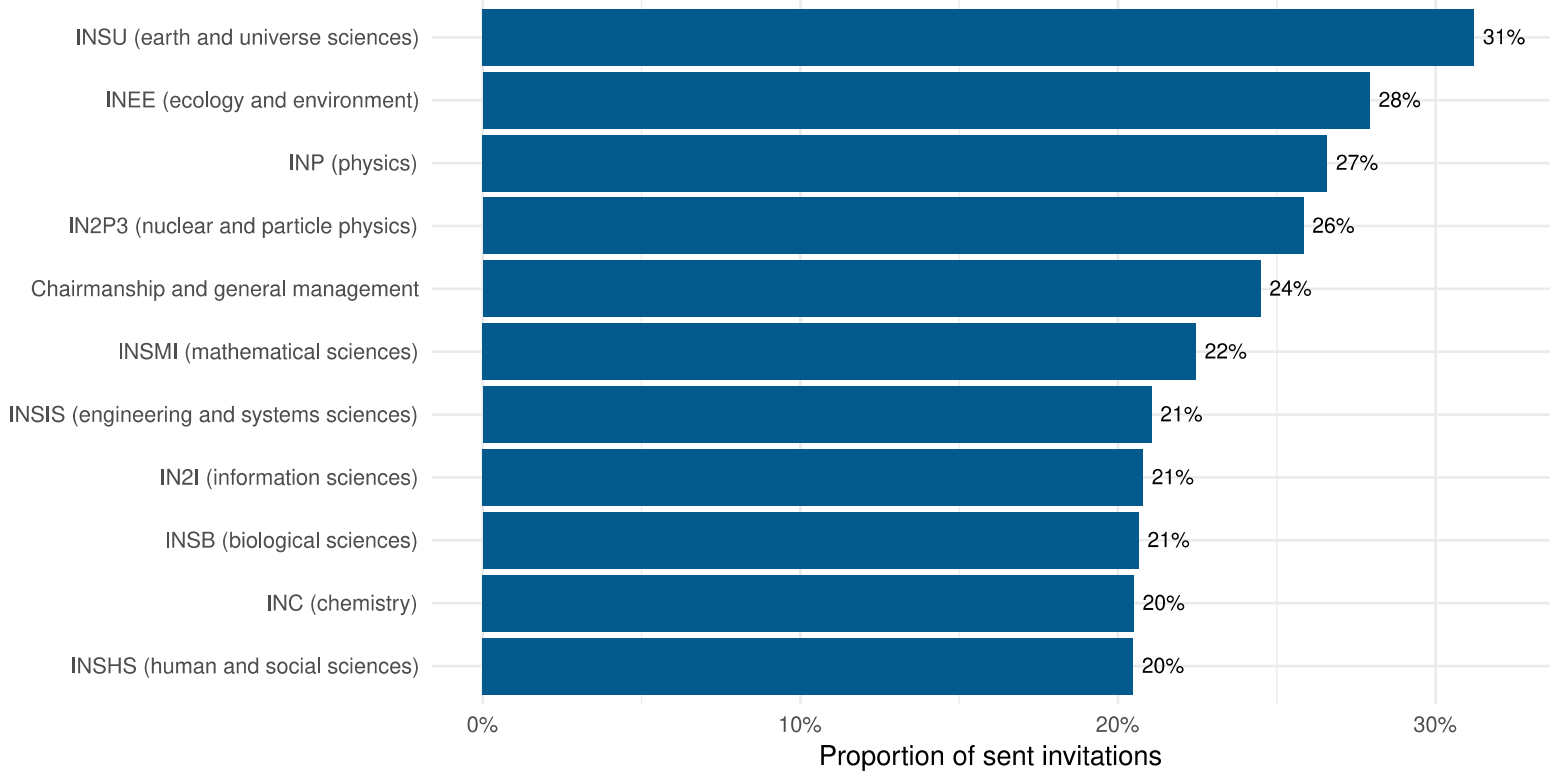




\section{Differences between early and late respondents}

One method of analyzing non-response biases consists in examining the trend over time in the characteristics of respondents. This aspect has been analyzed in several studies (for example, [39-42]). By identifying who participated in the survey at a later stage, after several reminders, we can attempt to understand who did not respond. The underlying reasoning is that late respondents would have been non-respondents if reminders had not been sent [42].

By means of a question on how concerned the respondent is about climate change, we can note that more early respondents than late respondents say they are 'Extremely concerned' by climate change (33\% of respondents before the first reminder compared with $27 \%$ after the last reminder). More early respondents say they 'strongly agree' that a major ecological catastrophe is going to occur (61\% compared with $50 \%$ after the last reminder). More early respondents had also carried out a carbon assessment. The greater concern for the environment on the part of early respondents is also reflected in a greater propensity to fully complete the questionnaire, which appears to suggest that they are more motivated to respond to the survey. The phenomenon of late respondents providing more incomplete data has already been identified in other surveys $[43,44]$.

Overall, early respondents are more in favour than late respondents of introducing regulatory constraints to protect the environment (respectively, $47 \%$ and $40 \%$ 'strongly agree'). The former are also more inclined to think that we need to protect the environment more than economic growth (58\% versus $47 \%)$. Concerning research specifically, early respondents think more often that this sector should set an example in terms of reducing GHG emissions $(50 \%$ vs $42 \%$ ). Early respondents are more inclined to consider many of the collective solutions proposed in the questionnaire as a priority, such as limiting air travel ( $56 \%$ vs $51 \%)$, reducing the weight of international conferences in career assessments, funding train tickets $(64 \%$ vs $56 \%$ ), and integrating $\mathrm{GHG}$ emissions into project-funding criteria.

But the distinction between early and late respondents is not systematic, whether in terms of opinions or ecological commitment. Only a small percentage of both groups think it is pointless to take steps to protect the environment if others fail to do so. They also share the same opinion on taking ecology into account when voting or joining or donating to an environmental protection organization. Members of each of the two groups are divided regarding the ability of more and better technology to solve environmental problems.

These observations are valid when controlled for age, sex, discipline, and status (see linear regression results in section 1.2 of S1 Appendix). Age is one of the characteristics with the greatest impact on response time. The youngest individuals required a half reminder message less than the oldest individuals. Differences between disciplines are slighter and, for the most part, not statistically significant. Differences in status could in part be related to differential variations in the workload over time, as occupations with the fastest response times at the end of the university year were not the same in the back-to-school period.

Lastly, a set of indicators suggests that the individuals most engaged in their work environment or those feeling the happiest about their work are more inclined to respond. The individuals with the fastest response times work less on a part-time basis and have had more work published in the last three years. They also see themselves more as being in a moment in their career in which they are seeking to be promoted, recruited or tenured, and consider that they are paid better. In a further observation, non-French nationals respond later to the questionnaire. 


\section{Comparison with other surveys}

A final method for assessing non-response biases is to compare our survey with others that have no reason to suffer from the same bias. This is true of the 'Styles de vie et environnement' (lifestyles and environment) survey based on the ELIPSS panel, which is a random sample panel of individuals living in France who have committed to respond to a broad variety of subjects, not limited to ecology. $90 \%$ of individuals with higher-level occupations in the civil service said they were somewhat or very concerned by climate change (compared with $93 \%$ in our survey, including when considering solely the sub-sample of higher-level occupations). $42 \%$ of them strongly agree with the statement, 'If things continue at the current pace, we will soon experience a major ecological catastrophe' (compared with $59 \%$ in our survey). These comparisons do not appear to reveal a major bias in our survey, as the latter difference could reflect, at least in part, a real difference between individuals with higher-level occupations in the civil service in general and researchers in particular, who as scientists are potentially more familiar with ecological issues.

Another survey, administered in spring 2020 among European demography researchers [45], may also be used as a reference as ecology was not its main theme. $91 \%$ of respondents said they were somewhat, very, or extremely concerned by climate change and $69 \%$ very or extremely concerned. These figures are very close to those obtained in our survey $(93 \%$ and $71 \%$, respectively, and $97 \%$ and $82 \%$ for researchers in sociology and demography).

\section{Results}

\section{Consensus on the gravity of climate issues}

A strong consensus exists on the reality, causes, and consequences of climate change among French research personnel. $99 \%$ of the respondents think that 'the climate of the planet is changing' and $95 \%$ think that human activity plays a major role in, or is the only cause of, climate change (Table 1). This result can be compared with the fact that $80 \%$ of French people think that 'global warming is caused by human activity' and just $66 \%$ of them consider that climate change is a certainty for most scientists [46].

This consensus on the reality of the situation and the underlying reasons is accompanied by an equally unanimous sense of concern. A full $99 \%$ of the respondents say they are concerned about climate change, $72 \%$ of them very or extremely concerned (including $32 \%$ extremely concerned). The concern of research personnel observed in our survey has increased in the last few years, with $80 \%$ of respondents saying they are more concerned than five years ago (including $45 \%$ much more concerned). And regarding the consequences of global warming, $90 \%$ of the respondents agree with the statement, 'If things continue on their present course, we will soon experience a major ecological catastrophe'. $74 \%$ of them even think that 'this type of catastrophe could cause a collapse of our societies'.

This vision of reality and the concerns of the respondents come hand in hand with a widely held expectation for changes in practices in their occupational activity. A full $88 \%$ of the respondents say they agree with the statement, 'Climate urgency calls for profound changes in the practice of our professions' (47\% saying they strongly agree). This strong desire for change is confirmed when the question is asked in a more concrete fashion, referring to the objective in France's Low-Carbon Strategy on a one-third reduction in GHG emissions by 2030. A full $91 \%$ of respondents agree with the objective of reducing carbon emissions from research by one-third by 2030 . And $48 \%$ even want to set an example by reducing them by more than onethird. 
Opinions on climate change differ little from one discipline to the next. In general, there are no more than five percentage points of variation from the average between disciplines. All disciplines agree on the certainty of climate change, the role played by human activities in that change, and the demand for radical changes in our professions. However, individuals in some disciplines, such as physics, chemistry, medical research, and biology, are less convinced that research should set an example in the reduction of GHG emissions (around 40\% compared with an average for all disciplines of $48 \%$ ). In contrast, oceanographers, meteorologists, environmental physicists, population biologists, and ecologists are more firmly convinced that the situation is urgent and action needs to be taken.

The status of personnel plays an important role in the responses. Surprisingly, while PhD-level positions (including PhD students) are more concerned about climate change than support staff, the latter are more willing to change research conditions to reduce GHG emissions. Just $62 \%$ of research support assistants say they are very or extremely concerned about climate change, compared with $76 \%$ of researchers. Conversely, $48 \%$ of research support engineers strongly agree with the idea that climate change calls for profound changes in our professions, compared with $40 \%$ of senior researchers or full professors.

Table 1. Opinions regarding climate and ecological issues

Do you think the climate of the planet is changing (rise in temperatures in the last century)?

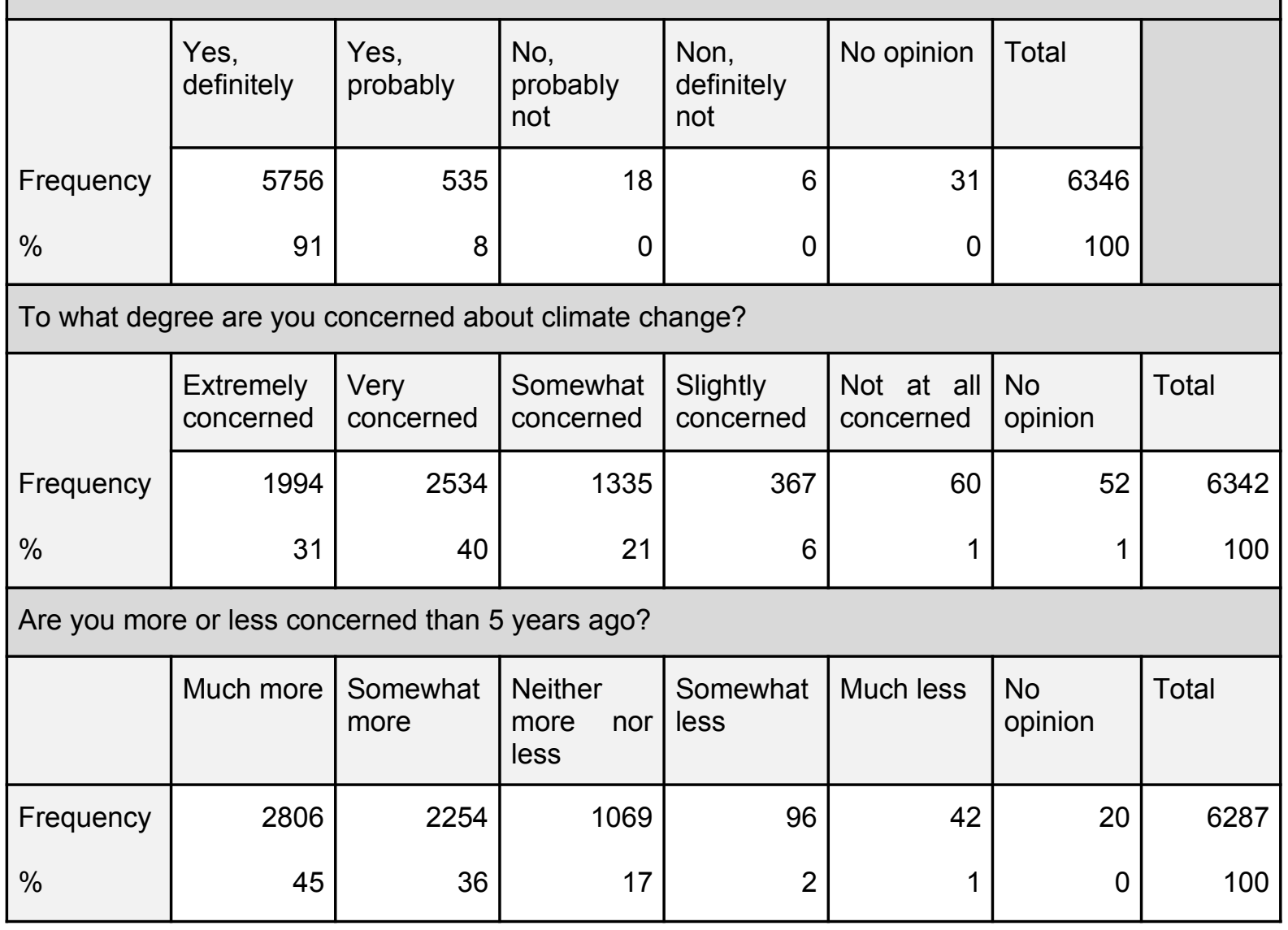


In your opinion, are human activities the cause of this climate change?

\begin{tabular}{|c|c|c|c|c|c|c|}
\hline & $\begin{array}{l}\text { Yes, they } \\
\text { are the } \\
\text { only cause }\end{array}$ & $\begin{array}{l}\text { Yes, they } \\
\text { play a } \\
\text { major role }\end{array}$ & $\begin{array}{l}\text { Yes, they } \\
\text { play a } \\
\text { small role }\end{array}$ & $\begin{array}{lr}\text { No, they } \\
\text { play no } \\
\text { role }\end{array}$ & No opinion & Total \\
\hline Frequency & 1159 & 4871 & 197 & 9 & 46 & 6282 \\
\hline$\%$ & 18 & 78 & 3 & 0 & 1 & 100 \\
\hline
\end{tabular}

Do you think that climate urgency calls for profound changes in the practice of our professions?

\begin{tabular}{|l|l|l|l|l|r|r|}
\hline & $\begin{array}{l}\text { Yes, } \\
\text { strongly } \\
\text { agree }\end{array}$ & $\begin{array}{l}\text { Yes, } \\
\text { somewhat } \\
\text { agree }\end{array}$ & $\begin{array}{l}\text { No, } \\
\text { somewhat } \\
\text { disagree }\end{array}$ & $\begin{array}{l}\text { No, } \\
\text { strongly } \\
\text { disagree }\end{array}$ & No opinion & Total \\
\cline { 2 - 7 }$\%$ & 2996 & 2594 & 397 & 107 & 247 & 6341 \\
47 & 41 & 6 & 2 & 4 & 100
\end{tabular}

If things continue on their present course, we will soon experience a major ecological catastrophe

\begin{tabular}{|l|l|l|l|l|l|l|}
\hline & $\begin{array}{l}\text { Yes, } \\
\text { strongly } \\
\text { agree }\end{array}$ & $\begin{array}{l}\text { Yes, } \\
\text { somewhat } \\
\text { agree }\end{array}$ & $\begin{array}{l}\text { No, } \\
\text { somewhat } \\
\text { disagree }\end{array}$ & $\begin{array}{l}\text { No, } \\
\text { strongly } \\
\text { disagree }\end{array}$ & No opinion & Total \\
\cline { 2 - 7 } Frequency & 3337 & 1788 & 198 & 97 & 265 & 5685 \\
$\%$ & 59 & 31 & 3 & 2 & 5 & 100 \\
\hline
\end{tabular}

This type of catastrophe could cause a collapse of our societies: the basic needs (food, energy, health, etc.) will no longer be assured for the majority of the population

\begin{tabular}{|l|l|l|l|l|l|l|}
\hline & $\begin{array}{l}\text { Yes, } \\
\text { strongly } \\
\text { agree }\end{array}$ & $\begin{array}{l}\text { Yes, } \\
\text { somewhat } \\
\text { agree }\end{array}$ & $\begin{array}{l}\text { No, } \\
\text { somewhat } \\
\text { disagree }\end{array}$ & $\begin{array}{l}\text { No, } \\
\text { strongly } \\
\text { disagree }\end{array}$ & No opinion & Total \\
\cline { 2 - 8 } Frequency & 2045 & 2105 & 489 & 361 & 605 & 5605 \\
$\%$ & 36 & 38 & 9 & 6 & 11 & 100 \\
\hline
\end{tabular}

France has committed to reducing its greenhouse gas emissions by one third by 2030 . In this respect, do you think that public research must reduce its emissions by

\begin{tabular}{|l|r|l|l|l|}
\hline \multirow{2}{*}{ Frequency } & $\begin{array}{l}\text { More than } \\
\text { one-third }\end{array}$ & $\begin{array}{l}\text { Around } \\
\text { one-third }\end{array}$ & $\begin{array}{l}\text { More than } \\
\text { one-third }\end{array}$ & Total \\
\cline { 2 - 5 }$\%$ & 2717 & 2423 & 495 & 5635 \\
48 & 43 & 9 & 100 \\
\hline
\end{tabular}




\section{High-emissions practices: air travel and IT equipment}

The respondents agree on the climate situation and share the same concerns. But the practices and habits of the research sector emit substantial amounts of greenhouse gases, notably through air travel, experimental equipment, buildings and infrastructure, IT equipment and its renewal, and receptions at conferences. To explore how research personnel aim to reduce these emissions, and to understand any reticence on their part, we need to know how much greenhouse gas is emitted and why, as emissions levels and reasons differ according to discipline and status. To that end, we will focus on two sources of emissions: air travel and IT equipment.

Excluding the research sector and at global level, the GHG emissions generated by air travel result from a minority of individuals (11\% of the world population took a plane in $2018,4 \%$ for an international flight), which explains in part why they account for just $2 \%$ of worldwide emissions [47]. But air travel is a widespread practice in research, constituting the sector's number-one source of emissions (see above).

Professional travel is part and parcel of today's research work, notably for conferences abroad, fieldwork or observations in distant countries, research stays, teaching, and participation on juries or in international research programmes. As they are faster than trains, sometimes cheaper, and can be used to travel to far-flung destinations, planes are often the preferred means of transport for research personnel. As research support personnel have more modest travel requirements, we are limiting our analysis here to PhDlevel positions (including PhD students), who account for $77 \%$ of our sample.

$58 \%$ of $\mathrm{PhD}$-level respondents travelled by plane for professional reasons in 2019. By way of comparison, in France in 2017, one person in five with an occupation of the same level travelled by plane at least once for professional reasons; this was the case for individuals with higher-level occupations in the civil service and similar sectors (teachers and artistic occupations) and for individuals with higher-level occupations in the private sector. Yet these are the professions that fly the most, and by far, as only $7 \%$ of the economically active population flying for professional reasons in the same year ('Styles de vie et environnement' survey, ELIPSS 2017, processed by the authors). Research personnel, then, are heavy users of air travel. On average, they flew $9,000 \mathrm{~km}$ in the year preceding the survey, emitting approximately 2 tonnes of $\mathrm{CO}_{2} \mathrm{e}$, and those having flown at least once travelled $15,500 \mathrm{~km}$ (the method for calculating distances and GHG emissions is detailed in S2 Appendix).

But the use of air travel varies considerably according to academic discipline. In some disciplines, where air travel is common, a researcher flies an average $10,000 \mathrm{~km}$ to 15,000 $\mathrm{km}$ a year (Fig 3). This is the case for astronomy, geology, anthropology, and mathematics, as well as for some disciplines focused on research on the environment and climate, which explains why researchers in the latter two fields were the first to question themselves on their paradoxical use of air travel [1]. Air travel is less frequent in other disciplines such as biology, chemistry, the human sciences, and medical research, the distance traveled being three times lower on average. 
Fig 3. Distance traveled by plane in 2019 by discipline of respondents

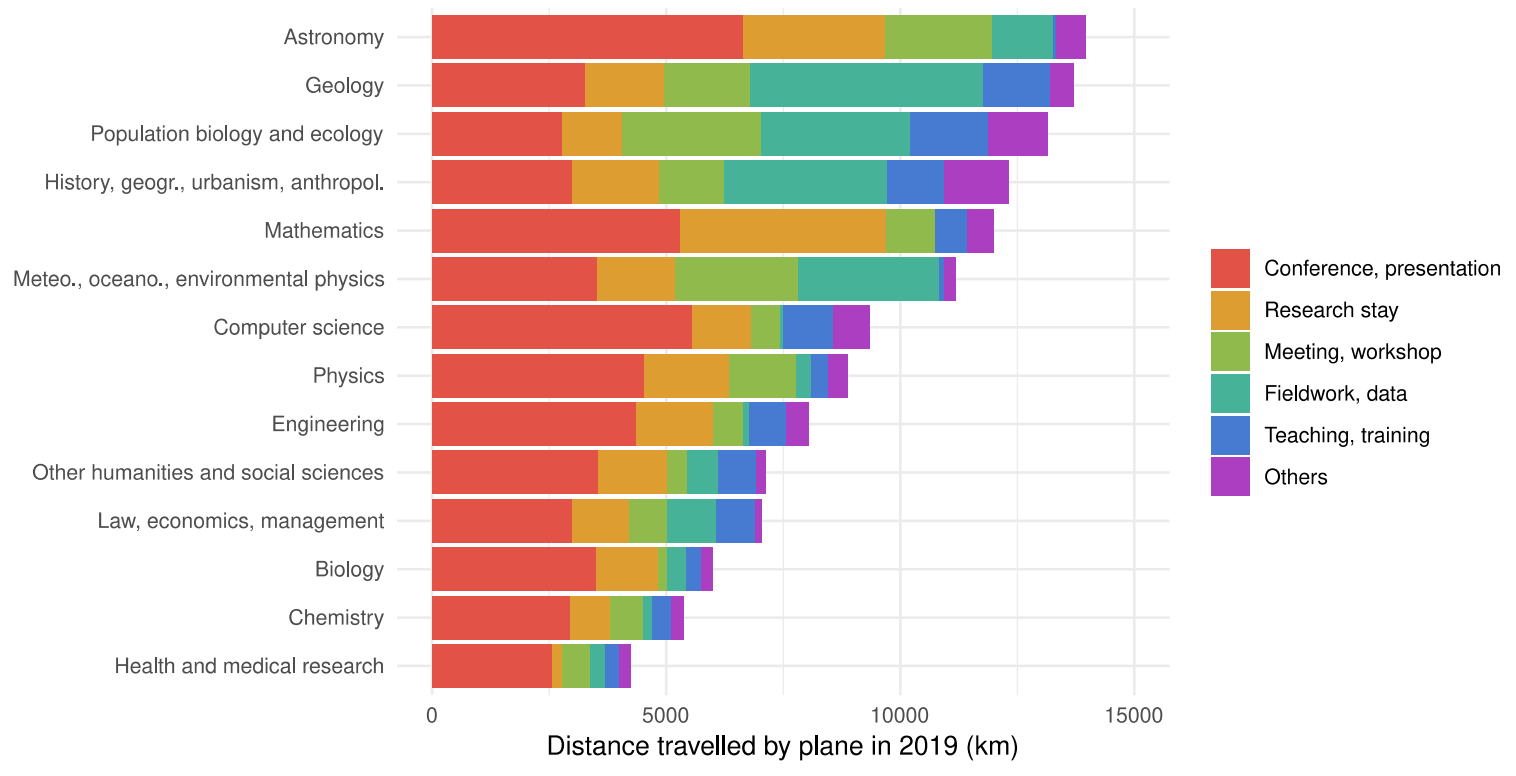

These differences in the use of air travel do not simply concern its intensity. Depending on the discipline, professionals do not fly for the same reasons. Geologists travel extensively for field studies, the production and collection of data, or research stays, but not so much to attend conferences. In contrast, astrophysicists, though flying as much as anthropologists, do so twice as less for data but twice as much for conferences. That being so, whether the individual belongs to a discipline that makes little or extensive use of air travel or to a discipline in which empirical activity requires them to fly or not to fly, in almost all cases conferences are the main reason for air travel. They account for roughly $40 \%$ of the distance travelled by all respondents. Data production and collection (11\% of the total distance) and research stays $(18 \%)$ account for far fewer flights.

Naturally, such variations exist not just between disciplines but between different statuses. Research personnel travel more as their careers advance (Fig 4), which confirms results in the literature and generalizes them to multiple disciplines and institutions [7,12,28,30]. Also, researchers travel more than professors, the latter devoting half of their work time to teaching. While senior researchers fly an average $15,000 \mathrm{~km}$ a year, full professors fly only slightly over $10,000 \mathrm{~km}$. Tenured researchers fly an average 10,000 km a year, associate professors around 7,000 km, and research engineers 5,500 km. Among young researchers, postdoctoral researchers travel nearly $8,000 \mathrm{~km}$ by air a year, twice as much as fully funded $\mathrm{PhD}$ students, with adjunct lecturers falling in between.

The reasons for air travel are fundamentally similar across statuses. While air travel distances differ, the reasons for flying vary relatively little. $40 \%$ to $50 \%$ of the air travel of the respondents is for conferences, apart from research engineers, who travel much less for this reason, and postdoctoral researchers, who travel much more for it. Research engineers, $\mathrm{PhD}$ students and adjunct lecturers devote a larger proportion of their flying distances to fieldwork and data. Conversely, the distance travelled for research stays increases as individuals advance in their careers, with the exception of $\mathrm{PhD}$ students who are the status with the highest proportion of distances flown for this motive. Logically, air travel for teaching concerns professors (both associated and full) more than other statuses. 
Fig 4. Distance traveled by plane in 2019 by status of respondents

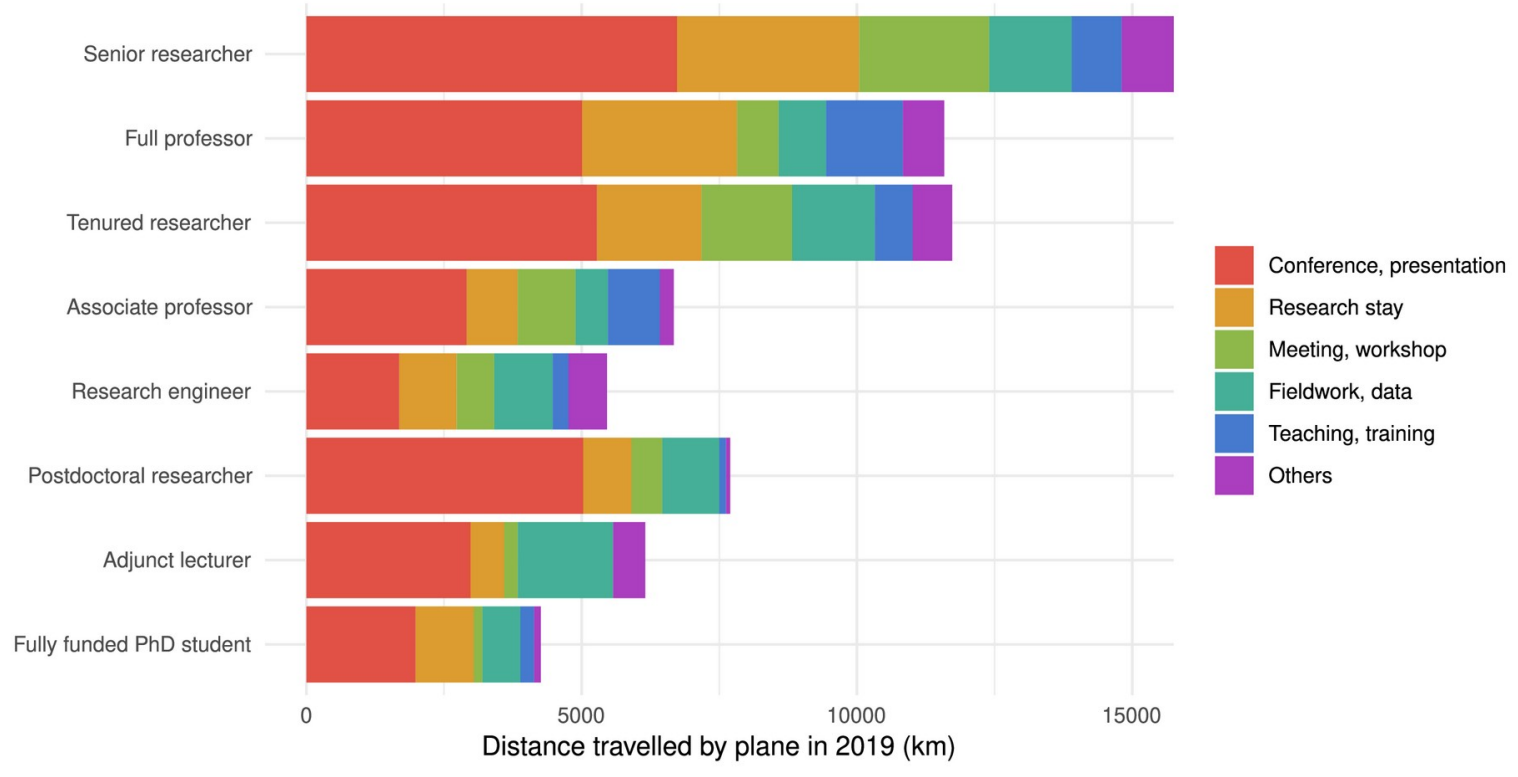

See S4 Appendix for the correspondence with French statuses.

IT equipment is another major source of the GHG emissions and, more broadly, the pollution of the research sector. This equipment emits less pollution than air travel, the functioning of buildings, and heavy scientific equipment used in some disciplines, but it is interesting because it concerns all disciplines and may be measured relatively reliably through an individual questionnaire. It is also a field in which emissions reduction initiatives may potentially be implemented as regards the frequency of equipment replacements, without necessarily impacting core research activities.

To estimate the environmental cost, and notably the GHG emissions of IT, the focus is often placed exclusively on the energy consumed by equipment use. Yet the lifecycle ('cradle to grave') of the equipment also needs to be considered. The production of IT equipment accounts for over half of the total GHG emissions [48] and consumes extensive resources, notably rare-earth metals. In addition, IT equipment produces a substantial quantity of hazardous waste at end of life (waste electrical and electronic equipment, or WEEE), which is complex and costly to recycle.

To give an idea of scale, over its life cycle, a laptop emits approximately $150 \mathrm{~kg}$ of $\mathrm{CO}_{2} \mathrm{e}$, a desktop computer $200 \mathrm{~kg}$, a high-performance computer $400 \mathrm{~kg}$, and a 21.5 -inch screen 250 $\mathrm{kg}$ [48]. Lengthening the lifespan of equipment would sharply reduce the corresponding emissions.

Our survey shows that most research personnel are equipped with IT devices (a computer or tablet purchased with professional financing) under five years old (62\% of respondents). More importantly, $42 \%$ of the respondents have several devices, and among the latter $40 \%$ (or $17 \%$ of the total sample) consider that some of those devices are not indispensable. This suggests that there is some scope for reducing the emissions generated by IT equipment, through the more frugal management of devices.

Major differences are observed between disciplines and statuses. The share of respondents with a device aged under five years old is higher in the natural sciences, mathematics, and computer science (between $60 \%$ and $73 \%$ ) than in humanities and social sciences $(47 \%$ to $55 \%)$. The same trend is observed regarding the proportion of respondents with several devices. The share of respondents considering that all these devices are not indispensable 
varies little from one discipline to the next. Lastly, and unsurprisingly, the number and recentness of devices increases in step with professional status (30\% of adjunct lecturers have a device aged under five years old compared with $69 \%$ of senior researchers). The same trend can thus be observed as with air travel.

The fact that personnel possess devices that they do not consider as indispensable can be attributed in part to project-based research funding, which may lead to expenditure of questionable usefulness to use up any credits that have not been spent before the end of the contract. $60 \%$ of the respondents say they have already had some leftover money to spend. Of this $60 \%, 35 \%$ say they had already used leftover money to buy IT equipment that was not indispensable.

However, only $6 \%$ of the respondents concerned report having used leftover budget money to buy plane tickets considered as non-essential. Air transport emissions being particularly high, the GHG emissions of this expenditure, seen as non-essential, may nevertheless be substantial. These results underscore some of the perverse effects of funding research on a project-by-project basis or via non-extendable annualized credits. They call at the very least for new mechanisms enabling personnel to use the funds granted in a manner that they see as more productive for their research.

\section{Scientific community willing to change practices}

So what needs to be done? How is this strong ecological sensibility reflected in the perceptions research personnel have of their profession? What do they see as the necessary changes required for reducing the GHG emissions of their research activity?

Several questions serve to identify the fields (air travels, experiments, etc.) in which respondents are willing to make the effort to reduce their emissions by 2030 and those in which they are less inclined to do so. Since the time horizon calls for medium-term planning, questions concerning individual efforts were asked only to permanent personnel. However, more general questions, with no specified time frame, and regarding the solutions to be rolled out and the risks involved, were asked to all the respondents.

Regardless of the field, most respondents say they are willing to reduce their emissions by at least one-third by 2030 (Fig 5). This is particularly true concerning air travel for conferences and IT equipment, with just $2 \%$ and $7 \%$, respectively, of the respondents saying they are opposed to reducing the related emissions. And while a few variations were observed depending on status and discipline, the percentage remains under $10 \%$ in almost all cases (results detailed in S1 Appendix).

Opposition is stronger for changes regarding core research activities. $14 \%$ of concerned respondents are opposed to reducing emissions stemming from travel for fieldwork, observation, and data collection. Similarly, nearly one-quarter are against reducing the emissions generated by scientific experiments and observations. This reluctance is even stronger concerning the concrete means for achieving these reductions, being expressed by $42 \%$ of the sample when envisioning a reduction in their use of equipment for experiments and observations.

A willingness to limit emissions does not imply that one believes it is without consequences or without danger. We asked the respondents to assess the risks that could be involved in the reduction of professional air travel (regardless of the reason) and the reduction of emissions generated by experimental equipment in the next ten years.

While the respondents are globally in favour of a reduction in professional air travel, many of them say it could engender some of the risks we presented to them and that these risks are problematic. For example, many of the respondents (54\%) are afraid that it poses a risk to the professional integration of young researchers. In something of a paradox, this fear is 
expressed slightly more by people further along in their careers than the young researchers themselves. Many of the respondents $(44 \%)$ are also afraid that this could increase bureaucracy. Further concerns among the respondents are that initiatives to reduce emissions could harm the dissemination of their work $(36 \%)$ and isolate French research from the rest of the world $(43 \%)$, the latter being more of an issue for researchers and professors for PhD students, postdoctoral researchers, adjunct lecturers, and support staff. Fears that these actions could hinder access to funding (16\%) and eliminate some of the advantages of the profession (like travelling and discovering other countries...) (11\%) are less frequent. Regarding this last point, most respondents think that cutting down on air travel will eat away at what they see as the innate advantages of the profession, but that this does not pose a problem. This result can be interpreted as a sign of willingness consistent with the strong convictions in favour of the climate expressed in response to the other questions.

\section{Fig 5. Willingness to reduce GHG emissions by 2030 in various areas}

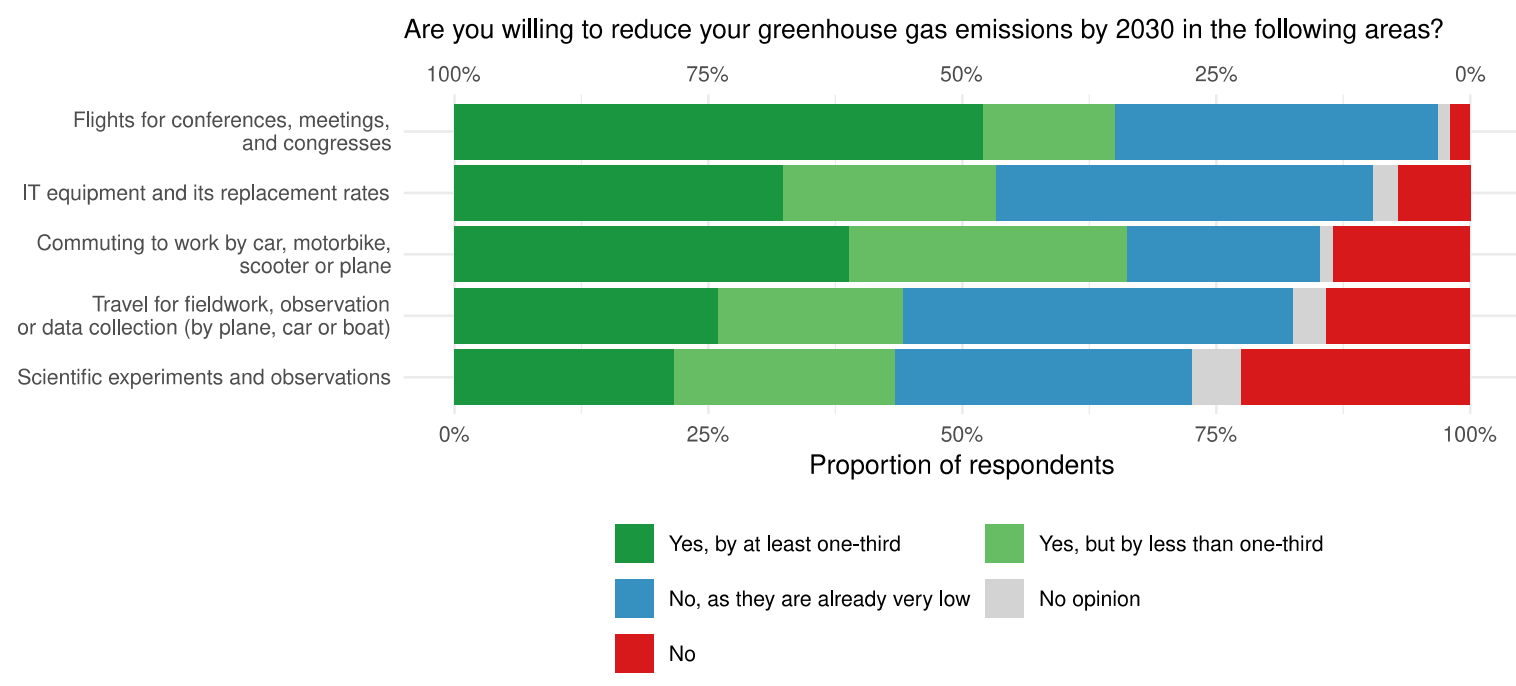

The proportion of respondents concerned varies according to the question.

These risks affect the functioning of research as currently organized (career paths, administrative and financial framework, etc.). But what about when the measures suggested in the questionnaire affect the scientific approach in itself (data production, experiments, etc.)?

Surprisingly, very few respondents (18\%) are worried about the harmful impact of the reduction of professional air travel on the quality of scientific work. The level of concern in this respect varies substantially according to the discipline, with no relation to the distance traveled. However, of the half of the respondents who use air travel to access some field sites or to collect/produce some data, many (47\%) think that implementing a policy on the reduction of air travel would hinder them in this regard and that it is a problem. This risk is seen as greater in disciplines where it is common to travel long distances by plane to produce or collect data (this is the case for $72 \%$ of historians, geographers, urbanists and anthropologists, $73 \%$ of geologists and $61 \%$ of population biologists and ecologists).

Generally speaking, where the empirical approach, data and experiments are affected, the respondents are more concerned about the risks associated with a decrease in emissions, which is consistent with their being less willing to reduce their emissions in these areas. When we suggested to respondents using experimental and observation equipment $(60 \%$ of the sample) that they reduce the emissions generated by this equipment, half of them said it would probably impact the quality of their work. Much mention is also made of the risks 
stemming from competition-based research, with $44 \%$ of respondents fearing that it would set them back relative to rival teams, $33 \%$ that it would reduce their access to funding, and $29 \%$ that it would lead to a decline in their number of publications.

These fears being so, what type of collective solutions should be implemented? A large majority of the respondents agree with the solutions suggested in the questionnaire (Fig 6). Almost all the respondents agree with the measures providing simply for a review (carbon assessment) or those coming at no cost for institutions, such as financing train travel where more expensive than plane travel, preferring to buy energy-efficient equipment even where more expensive, and funding carbon offsetting initiatives. Even measures that transform some career organization aspects are accepted by most respondents, as are others having a greater impact on the daily lives of the respondents. These include favouring local or vegetarian food stands, not replacing IT equipment before five years, and prohibiting air travel for journeys that take under six hours by train. Ultimately, the respondents express relatively strong opposition to just two measures: capping the number of flights per person $(22 \%)$ and integrating carbon emissions into the selection criteria when financing projects $(28 \%)$. These two initiatives, among the most radical, may for some disciplines impact the core of scientific data production.

\section{Fig 6. Support to institutional actions to reduce GHG emissions}

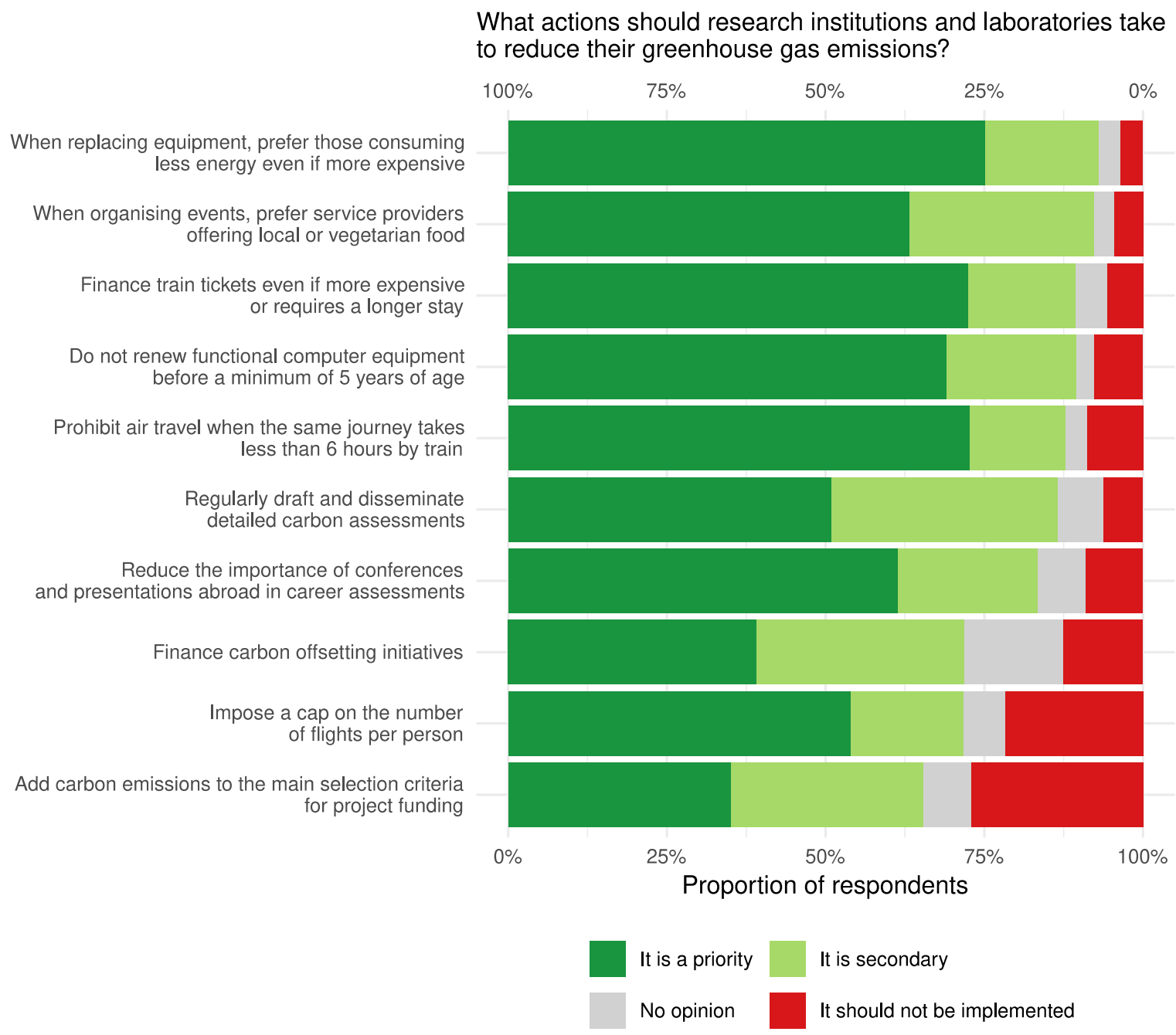




\section{Conclusion}

Our survey highlights three results. First, members of the scientific community are acutely aware of environmental issues. Second, they are willing to implement change. And third, there is a substantial divide between these attitudes and practices emitting large quantities of greenhouse gas. In today's post-health crisis environment, many research personnel have already tried out new working methods, particularly with the unprecedented increase in the use of videoconferencing [49]. A mere $8 \%$ of our respondents used videoconferencing several times a week before the lockdowns; $72 \%$ of them did so during the lockdowns. Most importantly, $68 \%$ of the respondents said they had a more positive image of videoconferencing following their lockdown experience despite the particularly trying situation and a lack of preparation. This result shows that new work organization methods acceptable to personnel may be implemented quickly where collective action is taken. More broadly, the pandemic demonstrated that individuals and organizations alike were able, when faced with a threat, to radically change their way of working. The lessons of the pandemic should inspire us to rethink the way research works [50].

The key now is for institutions to drive and support profound change to fight against climate change. The scientific community is ready to make these changes but, for now, its members are unable to implement them individually without running the risk of being negatively impacted owing to the way the research sector operates (promotion of mobility in career assessments, project-by-project funding, competition, etc.). Failing this institutional action, the necessary changes will not take place [51].

As an occupation with a highly developed awareness of climate issues, and one that generates high levels of greenhouse gas emissions, the research community is currently facing regulatory issues that all sectors will soon have to deal with.

\section{Acknowledgments}

We would like to thank all the members of the Labos 1 point5 collective whose suggestions helped improve the questionnaire, as well as all the volunteers who tested it. Support from the CNRS was also key to the success of the survey.

\section{References}

1. Grémillet D. Paradox of flying to meetings to protect the environment. Nature. 2008;455: 1175. doi:10.1038/4551175a

2. Kevin Anderson. Hypocrites in the air: should climate change academics lead by example? In: Comment on climate [Internet]. 12 Apr 2013 [cited 21 Jul 2020]. Available: http://kevinanderson.info/blog/hypocrites-in-the-air-should-climate-change-academicslead-by-example/

3. Fox HE, Kareiva P, Silliman B, Hitt J, Lytle DA, Halpern BS, et al. Why do we fly? Ecologists's sins of emission. Front Ecol Environ. 2009;7: 294. doi:10.1890/09.WB.019

4. Spinellis D, Louridas P. The carbon footprint of conference papers. PLOS One. 2013;8: 1-8. doi:10/ggbs2j

5. Le Quéré C, Capstick S, Corner A, Cutting D, Johnson M, Minns A, et al. Towards a culture of low-carbon research for the 21st Century. Tyndall Center for Climate Change Research; 2015 Mar. Report No.: 161. Available: https://tyndall.ac.uk/sites/default/files/twp161.pdf

6. Nevins J. Academic Jet-Setting in a Time of Climate Destabilization: Ecological Privilege and Professional Geographic Travel. Prof Geogr. 2014;66. doi:10.1080/00330124.2013.784954

7. Stevens ARH, Bellstedt S, Elahi PJ, Murphy MT. The imperative to reduce carbon 
emissions in astronomy. ArXiv191205834 Astro-Ph. 2020 [cited 30 Jun 2020]. Available: http://arxiv.org/abs/1912.05834

8. Passalacqua A. The carbon footprint of a scientific community: A survey of the historians of mobility and their normalized yet abundant reliance on air travel. J Transp Hist. 2021;42: 121-141. doi:10.1177/0022526620985073

9. Kjellman SE. As a climate researcher, should I change my air-travel habits? Nature. 2019 [cited 21 Jul 2020]. doi:10.1038/d41586-019-01652-2

10. Waring T, Teisl M, Manandhar E, Anderson M. On the Travel Emissions of Sustainability Science Research. Sustainability. 2014;6: 2718-2735. doi:10.3390/su6052718

11. Quéré CL, Capstick S, Corner A, Cutting D, Johnson M, Minns A, et al. Towards a culture of low-carbon research for the 21stCentury. 2015. Available: https://tyndall.ac.uk/sites/default/files/twp161.pdf

12. Ciers J, Mandic A, Toth LD, Op 't Veld G. Carbon Footprint of Academic Air Travel: A Case Study in Switzerland. Sustainability. 2019;11: 80. doi:10.3390/su11010080

13. ETH Zürich. Flugreisen Studierender an der ETH Zürich 2006 und 2015. Resultate, Methodik und Diskussion. Zürich; 2017 Oct. Available: https://ethz.ch/content/dam/ethz/associates/services/organisation/Schulleitung/ mobilitaetsplattform/Report\%20Studierendenreisen\%20ETH\%20Z\%C3\%BCrich \%202006\%20und\%202015.pdf

14. Howes L. Can Laboratories Move Away from Single-Use Plastic? ACS Cent Sci. 2019;5: 1904-1906. doi:10.1021/acscentsci.9b01249

15. Madhusoodanan J. What can you do to make your lab greener? Nature. 2020;581: 228229. doi:10.1038/d41586-020-01368-8

16. Choi YJ, Oh M, Kang J, Lutzenhiser L. Plans and Living Practices for the Green Campus of Portland State University. Sustainability. 2017. doi:10.3390/su9020252

17. Glover A, Strengers $Y$, Lewis $T$. The unsustainability of academic aeromobility in Australian universities. Sustain Sci Pract Policy. 2017;13: 1-12. doi:10.1080/15487733.2017.1388620

18. Wynes S, Donner SD. Addressing greenhouse gas emissions from business-related air travel at public institutions: a case study of the University of British Columbia. Victoria: Pacific Institute for Climate Solutions; 2018 Jul. Available: pics.uvic.ca/sites/default/files/AirTravelWP_FINAL.pdf

19. Hischier R, Hilty L. Environmental impacts of an international conference. Environ Impact Assess Rev. 2002;22: 543-557. doi:10.1016/S0195-9255(02)00027-6

20. Desiere S. The Carbon Footprint of Academic Conferences: Evidence from the 14th EAAE Congress in Slovenia. EuroChoices. 2016;15: 56-61. doi:10.1111/1746$692 X .12106$

21. Vandepaer L. Environmental footprint Sustainable Summits Conference 2018. Chamonix-Mont-Blanc; 2018. doi:10.13140/RG.2.2.26703.53929

22. Astudillo MF, AzariJafari $\mathrm{H}$. Estimating the global warming emissions of the LCAXVII conference: connecting flights matter. Int J Life Cycle Assess. 2018;23: 1512-1516. doi:10.1007/s11367-018-1479-z

23. European Union. 2030 climate \& energy framework. 2021 [cited 8 Dec 2021]. Available: https://ec.europa.eu/clima/eu-action/climate-strategies-targets/2030-climate-energyframework_en

24. Klöwer M, Hopkins D, Allen M, Higham J. An analysis of ways to decarbonize conference travel after COVID-19. Nature. 2020;583: 356-359. doi:10.1038/d41586020-02057-2

25. Achten WMJ, Almeida J, Muys B. Carbon footprint of science: More than flying. Ecol Indic. 2013;34: 352-355. doi:10.1016/j.ecolind.2013.05.025

26. Song G, Che L, Zhang S. Carbon footprint of a scientific publication: A case study at Dalian University of Technology, China. Ecol Indic. 2016;60: 275-282. doi:10/f75dj2

27. Storme T, Beaverstock JV, Derrudder B, Faulconbridge JR, Witlox F. How to cope with mobility expectations in academia: Individual travel strategies of tenured academics at Ghent University, Flanders. Res Transp Bus Manag. 2013;9: 12-20. 
doi:10.1016/j.rtbm.2013.05.004

28. Wynes S, Donner SD, Tannason S, Nabors N. Academic air travel has a limited influence on professional success. J Clean Prod. 2019;226: 959-967.

doi:10.1016/j.jclepro.2019.04.109

29. Cluzel F, Vallet F, Leroy Y, Rebours P. Reflecting on the environmental impact of research activities: an exploratory study. Procedia CIRP. 2020;90: 754-758. doi:10.1016/j.procir.2020.01.129

30. Whitmarsh L, Capstick S, Moore I, Köhler J, Le Quéré C. Use of aviation by climate change researchers: Structural influences, personal attitudes, and information provision. Glob Environ Change. 2020;65: 102184. doi:10.1016/j.gloenvcha.2020.102184

31. Stohl A. The travel-related carbon dioxide emissions of atmospheric researchers. Atmospheric Chem Phys. 2008;8: 6499-6504. doi:10.5194/acp-8-6499-2008

32. Howarth $\mathrm{C}$, Waterson $\mathrm{B}$, Mcdonald M. Public understanding of climate change and the gaps between knowledge, attitudes and travel behavior. Transportation Research Board 88th Annual Meeting. Washington DC; 2009. Available:

https://www.researchgate.net/publication/313211885_Public_understanding_of_climate_ change_and_the_gaps_between_knowledge_attitudes_and_travel_behavior

33. Alcock I, White MP, Taylor T, Coldwell DF, Gribble MO, Evans KL, et al. 'Green' on the ground but not in the air: Pro-environmental attitudes are related to household behaviours but not discretionary air travel. Glob Environ Change. 2017;42: 136-147. doi:10.1016/j.gloenvcha.2016.11.005

34. Balmford A, Cole L, Sandbrook C, Fisher B. The environmental footprints of conservationists, economists and medics compared. Biol Conserv. 2017;214: 260-269. doi:10.1016/j.biocon.2017.07.035

35. Milfont TL, Duckitt J. The environmental attitudes inventory: A valid and reliable measure to assess the structure of environmental attitudes. J Environ Psychol. 2010;30: 80-94. doi:10.1016/j.jenvp.2009.09.001

36. SIES. L'état de l'emploi scientifique en France. Paris: Ministère de l'Enseignement supérieur, de la recherche et de l'innovation; 2020. Available:

https://www.enseignementsup-recherche.gouv.fr/cid154848//-etat-de-I-emploiscientifique-en-france-edition-2020.html

37. Fan W, Yan Z. Factors affecting response rates of the web survey: A systematic review. Comput Hum Behav. 2010;26: 132-139. doi:10.1016/j.chb.2009.10.015

38. Pearson A, Ballew MT, Naiman S, Schuldt JP. Race, class, gender and climate change communication. Oxf Encycl Clim Change Commun. 2017. doi:10.1093/acrefore/9780190228620.013.412

39. Chen R, Wei L, Syme PD. Comparison of early and delayed respondents to a postal health survey: a questionnaire study of personality traits and neuropsychological symptoms. Eur J Epidemiol. 2003;18: 195-202. doi:10.1023/A:1023393231234

40. Gummer T, Struminskaya B. Early and Late Participation during the Field Period: Response Timing in a Mixed-Mode Probability-Based Panel Survey. Sociol Methods Res. 2020;Online First. doi:10.1177/0049124120914921

41. Olowokure B, Caswell M, Duggal HV. Response patterns to a postal survey using a cervical screening register as the sampling frame. Public Health. 2004;118: 508-512. doi:10.1016/j.puhe.2003.12.013

42. Rao K, Pennington J. Should the Third Reminder be Sent? The Role of Survey Response Timing on Web Survey Results. Int J Mark Res. 2013;55: 651-674. doi:10.2501/IJMR-2013-056

43. Friedman EM, Clusen NA, Hartzell M. Better Late? Characteristics of Late Respondents to a Health Care Survey. ASA Proc Jt Stat Meet. 2003; 992-998.

44. Kennickell AB. Analysis of nonresponse effects in the 1995 Survey of Consumer Finances. J Off Stat. 1997;15: 283-304.

45. van Dalen HP, Henkens K. Population and Climate Change: Consensus and Dissensus among Demographers. Eur J Popul. 2021. doi:10.1007/s10680-021-09580-6

46. ADEME. Les représentations sociales du changement climatique. $21^{\circ}$ vague, Juillet 
2020. 2020. Available: https://librairie.ademe.fr/changement-climatique-et-energie/4057representations-sociales-du-changement-climatique-21-eme-vague.html

47. Gössling S, Humpe A. The global scale, distribution and growth of aviation: Implications for climate change. Glob Environ Change. 2020;65: 102194. doi:10.1016/j.gloenvcha.2020.102194

48. ADEME. Modélisation et évaluation du poids carbone de produits de consommation et biens d'équipements. Paris; 2018. Available:

https://librairie.ademe.fr/cadic/1193/poids_carbone-biens-equipement-201809rapport.pdf

49. Glausiusz J. Rethinking travel in a post-pandemic world. Nature. 2021;589: 155-157. doi:10.1038/d41586-020-03649-8

50. Jordan CJ, Palmer AA. Virtual meetings: A critical step to address climate change. Sci Adv. 2020;6: eabe5810. doi:10.1126/sciadv.abe5810

51. Nursey-Bray M, Palmer R, Meyer-Mclean B, Wanner T, Birzer C. The Fear of Not Flying: Achieving Sustainable Academic Plane Travel in Higher Education Based on Insights from South Australia. Sustainability. 2019;11: 2694. doi:10.3390/su11092694

52. Jungbluth $\mathrm{N}$, Meili $\mathrm{C}$. Recommendations for calculation of the global warming potential of aviation including the radiative forcing index. Int J Life Cycle Assess. 2019;24: 404-411. 


\section{S1 Appendix. Additional tables and plots}

- 1 Sample and non-response bias

1.1 Response rate by status and discipline

- 1.2 Distribution of sample by discipline and status

- 1.3 Differences between early and late respondents

- 2 Opinions

- 2.1 Overview

- 2.2 Human activities and climate change

- 2.3 Concern about climate change

$\circ 2.4$ Change in degree of concern

- 2.5 Opinions on ecology in general

- 2.6 Profound changes in our professions

- 2.7 Reduction in emissions by one-third by 2030

- 3 Practices

- 3.1 Flights

- 3.1.1 Reasons for flying by discipline

- 3.1.2 Reasons for flying by status

- 3.2 IT equipment

- 3.3 Leftover budget money

- 4 Solutions

- 4.1 Reductions in personal GHG emissions in a professional setting by 2030

- 4.2 Risks associated with reduced flying

- 4.3 Reductions in personal GHG emissions of experimental equipment by 2030

- 4.4 Risks associated with reduced emissions of experimental equipment

- 4.5 Institutional solutions 
1 Sample and non-response bias 


\subsection{Response rate by status and discipline}

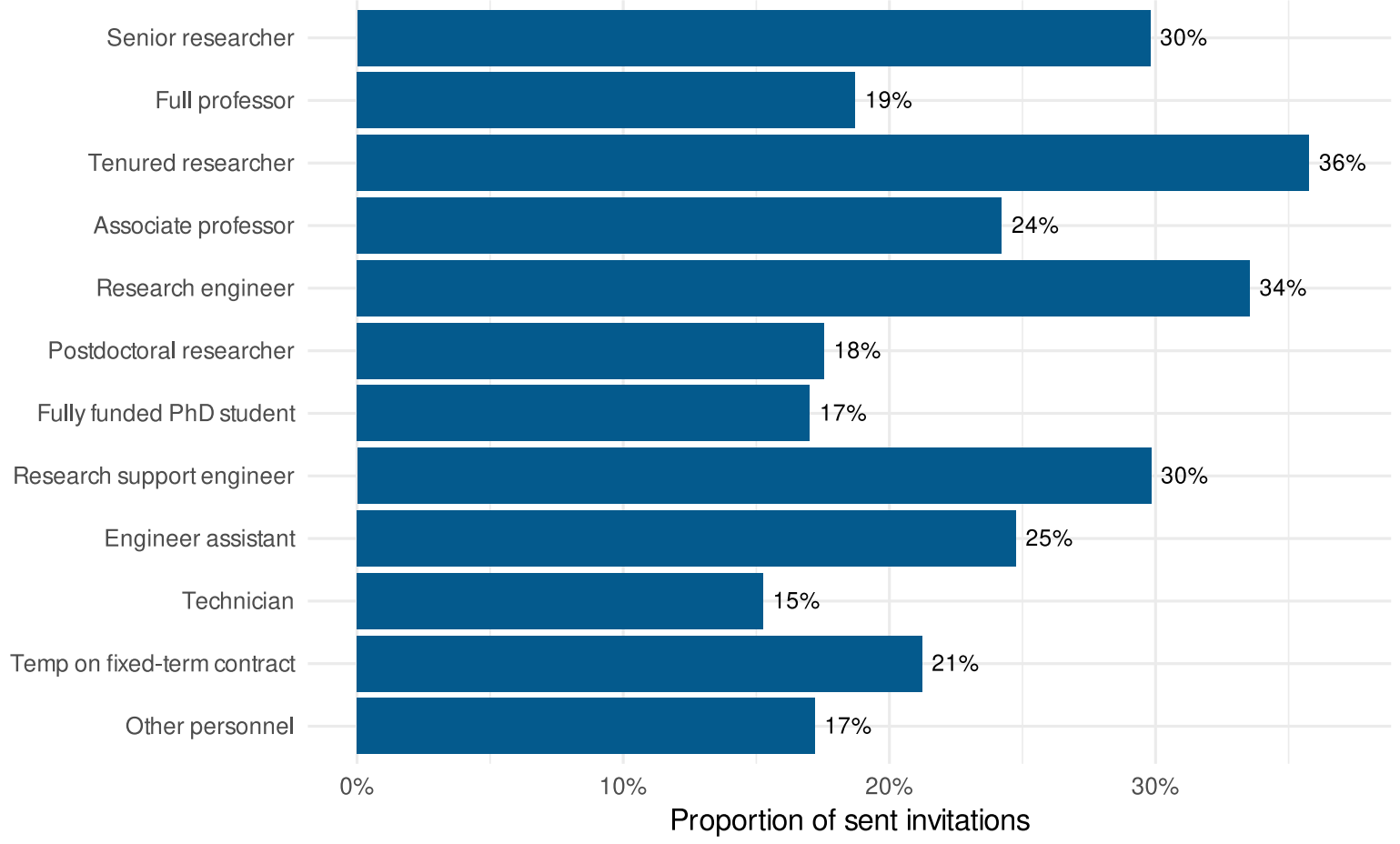

INSU (earth and universe sciences)

INEE (ecology and environment)

INP (physics)

IN2P3 (nuclear and particle physics)

Chairmanship and general management

INSMI (mathematical sciences)

INSIS (engineering and systems sciences)

IN2I (information sciences)

INSB (biological sciences)

INC (chemistry)

INSHS (human and social sciences)

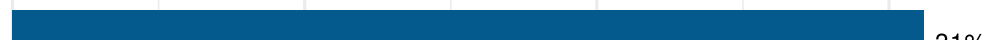

$31 \%$

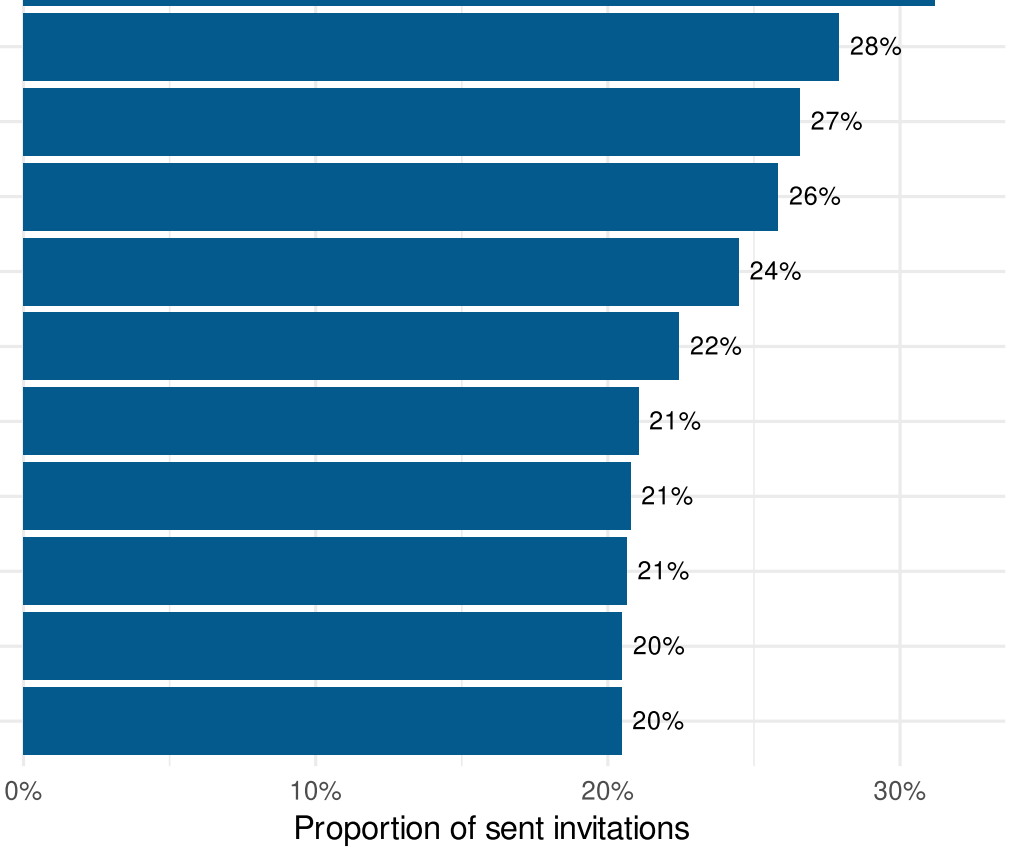

Logistic regression on the probability of response: 


\section{Institute}

INSU (earth and universe sciences)

INEE (ecology and environment)

INP (physics)

IN2P3 (nuclear and particle physics)

Chairmanship and general management

INSMI (mathematical sciences)

INSIS (engineering and systems sciences)

IN2I (information sciences)

$0.66 * * *$

$0.57,0.76$

INSB (biological sciences)

$0.56^{* * *}$

$0.50,0.63$

INC (chemistry)

$0.60 * * *$

$0.53,0.68$

INSHS (human and social sciences)

$0.65^{* * *}$

$0.58,0.73$

\section{Region}

01, lle-de-France Villejuif

02, Paris-Centre

04, Ile-de-France Gif-sur-Yvette

$1.20 *$

$1.03,1.40$

05, lle-de-France Meudon

1.16

$0.97,1.38$

06, Centre-Est

$1.21 *$

$1.02,1.44$

07, Rhône Auvergne

$1.25^{* *}$

$1.08,1.46$

08, Centre-Limousin-Poitou-Charentes

$1.37^{* *}$

$1.13,1.66$

10, Alsace

1.13

$0.94,1.36$

11, Alpes

$1.70^{* * *}$

$1.45,2.00$

12, Provence et Corse

$1.29 * *$

$1.10,1.52$

13, Occitanie Est

1.13

$0.95,1.34$

14, Occitanie Ouest

$1.18^{*}$

$1.01,1.38$

15, Aquitaine

1.26 *

$1.06,1.51$

16, Paris Michel-Ange

1.10

$0.86,1.41$

17, Bretagne et Pays de la Loire

18, Hauts-de-France

19, Normandie

20, Côte d'Azur

\section{Status}

Senior researcher

Full professor

Tenured researcher

Associate professor

Research engineer

Postdoctoral researcher

Fully funded PhD student 


\section{Variable}

Technician

Temp on fixed-term contract

Other personnel

\section{Odds ratio}

$95 \% \mathrm{Cl}$

$0.33,0.45$

$0.51,0.68$

$0.59 * * *$

$0.47 * * *$

$0.39,0.56$

Sex

Man

Woman

\subsection{Distribution of sample by discipline and status}

Law, economics, management

Other humanities and social sciences

History, geography, urbanism, anthropology

Mathematics

Computer science

Physics

Chemistry

Astronomy

Geology

Meteorology, oceanology, environmental physics

Health and medical research

Engineering

Biology

Population biology and ecology

NA

\begin{tabular}{rrr}
$\mathbf{n}$ & \% & val\% \\
\hline 364 & 5.6 & 6.0 \\
\hline 508 & 7.9 & 8.3 \\
535 & 8.3 & 8.8 \\
\hline 351 & 5.4 & 5.8 \\
\hline 395 & 6.1 & 6.5 \\
\hline 540 & 8.4 & 8.9 \\
\hline 669 & 10.3 & 11.0 \\
\hline 246 & 3.8 & 4.0 \\
\hline 235 & 3.6 & 3.9 \\
\hline 206 & 3.2 & 3.4 \\
\hline 572 & 8.8 & 9.4 \\
\hline 708 & 10.9 & 11.6 \\
\hline 547 & 8.5 & 9.0 \\
\hline 221 & 3.4 & 3.6 \\
\hline 370 & 5.7 & $N A$ \\
\hline
\end{tabular}

Senior researcher

Full professor

Tenured researcher

Associate professor

Research engineer

Postdoctoral researcher

Adjunct lecturer

Fully funded PhD student

Research support engineer

Research assistant/Project manager

Engineer assistant

Technician

Technical assistant

Other personnel

\begin{tabular}{rrr}
$\mathbf{n}$ & \% & val\% \\
\hline 612 & 9.5 & 9.5 \\
\hline 588 & 9.1 & 9.1 \\
741 & 11.5 & 11.5 \\
\hline 1085 & 16.8 & 16.8 \\
\hline 603 & 9.3 & 9.3 \\
\hline 252 & 3.9 & 3.9 \\
\hline 64 & 1.0 & 1.0 \\
\hline 938 & 14.5 & 14.5 \\
\hline 629 & 9.7 & 9.7 \\
\hline 41 & 0.6 & 0.6 \\
\hline 327 & 5.1 & 5.1 \\
\hline 225 & 3.5 & 3.5 \\
\hline 46 & 0.7 & 0.7 \\
\hline 315 & 4.9 & 4.9 \\
\hline 1 & 0.0 & $\mathrm{NA}$ \\
\hline
\end{tabular}




\subsection{Differences between early and late respondents}

To what degree are you concerned about climate change?

\begin{tabular}{|c|c|c|c|c|c|c|}
\hline & $\begin{array}{r}\text { After the first } \\
\text { message }\end{array}$ & $\begin{array}{l}\text { After the first } \\
\text { reminder }\end{array}$ & $\begin{array}{l}\text { After the second } \\
\text { reminder }\end{array}$ & $\begin{array}{l}\text { After the third } \\
\text { reminder }\end{array}$ & $\begin{array}{r}\text { After the fourth } \\
\text { reminder }\end{array}$ & All \\
\hline $\begin{array}{l}\text { Not at all } \\
\text { concerned }\end{array}$ & 1 & 0 & 1 & 1 & 1 & 1 \\
\hline $\begin{array}{l}\text { Slightly } \\
\text { concerned }\end{array}$ & 6 & 6 & 5 & 5 & 7 & 6 \\
\hline $\begin{array}{l}\text { Somewhat } \\
\text { concerned }\end{array}$ & 20 & 23 & 19 & 21 & 23 & 21 \\
\hline Very concerned & 39 & 40 & 44 & 42 & 41 & 40 \\
\hline $\begin{array}{l}\text { Extremely } \\
\text { concerned }\end{array}$ & 34 & 30 & 30 & 30 & 27 & 31 \\
\hline No opinion & 1 & 1 & 1 & 1 & 1 & 1 \\
\hline Total & 100 & 100 & 100 & 100 & 100 & 100 \\
\hline
\end{tabular}

If things continue on their present course, we will soon experience a major ecological catastrophe

\begin{tabular}{|c|c|c|c|c|c|c|}
\hline & $\begin{array}{r}\text { After the first } \\
\text { message }\end{array}$ & $\begin{array}{l}\text { After the first } \\
\text { reminder }\end{array}$ & $\begin{array}{l}\text { After the second } \\
\text { reminder }\end{array}$ & $\begin{array}{l}\text { After the third } \\
\text { reminder }\end{array}$ & $\begin{array}{r}\text { After the fourth } \\
\text { reminder }\end{array}$ & All \\
\hline $\begin{array}{l}\text { Completely } \\
\text { agree }\end{array}$ & 61 & 59 & 61 & 55 & 51 & 59 \\
\hline $\begin{array}{l}\text { Somewhat } \\
\text { agree }\end{array}$ & 29 & 31 & 31 & 33 & 39 & 31 \\
\hline $\begin{array}{l}\text { Somewhat } \\
\text { disagree }\end{array}$ & 3 & 3 & 3 & 4 & 4 & 3 \\
\hline $\begin{array}{l}\text { Completely } \\
\text { disagree }\end{array}$ & 2 & 1 & 1 & 2 & 1 & 2 \\
\hline No opinion & 4 & 5 & 4 & 5 & 6 & 5 \\
\hline Total & 100 & 100 & 100 & 100 & 100 & 100 \\
\hline
\end{tabular}

I agree with having regulatory constraints (quotas, bans) put in place to protect the environment, even if it limits my comfort

\begin{tabular}{|c|c|c|c|c|c|c|}
\hline & $\begin{array}{r}\text { After the first } \\
\text { message }\end{array}$ & $\begin{array}{l}\text { After the first } \\
\text { reminder }\end{array}$ & $\begin{array}{l}\text { After the second } \\
\text { reminder }\end{array}$ & $\begin{array}{l}\text { After the third } \\
\text { reminder }\end{array}$ & $\begin{array}{r}\text { After the fourth } \\
\text { reminder }\end{array}$ & All \\
\hline $\begin{array}{l}\text { Completely } \\
\text { agree }\end{array}$ & 47 & 46 & 49 & 41 & 38 & 45 \\
\hline $\begin{array}{l}\text { Somewhat } \\
\text { agree }\end{array}$ & 40 & 42 & 37 & 45 & 50 & 42 \\
\hline $\begin{array}{l}\text { Somewhat } \\
\text { disagree }\end{array}$ & 7 & 7 & 9 & 8 & 8 & 8 \\
\hline $\begin{array}{l}\text { Completely } \\
\text { disagree }\end{array}$ & 3 & 2 & 2 & 4 & 2 & 3 \\
\hline No opinion & 2 & 2 & 2 & 3 & 2 & 2 \\
\hline Total & 100 & 100 & 100 & 100 & 100 & 100 \\
\hline
\end{tabular}

Protecting the environment is more important than protecting economic growth 
Completely

58

56

58

51

$47 \quad 55$

agree

Somewhat

agree

Somewhat

6

6

7

7

87

disagree

Completely

2

2

12

disagree

No opinion

4

2

3

43

Total

100

100

100

100

100100

France has committed to reducing its greenhouse gas emissions by one-third by 2030 . In this respect, do you think that public research should:

\begin{tabular}{|c|c|c|c|c|c|c|}
\hline & $\begin{array}{r}\text { After the first } \\
\text { message }\end{array}$ & $\begin{array}{l}\text { After the first } \\
\text { reminder }\end{array}$ & $\begin{array}{l}\text { After the } \\
\text { second } \\
\text { reminder }\end{array}$ & $\begin{array}{l}\text { After the } \\
\text { third } \\
\text { reminder }\end{array}$ & $\begin{array}{l}\text { After the } \\
\text { fourth } \\
\text { reminder }\end{array}$ & All \\
\hline $\begin{array}{l}\text { Set an example (reduce emissions by more } \\
\text { than one-third) }\end{array}$ & 50 & 49 & 49 & 46 & 42 & 48 \\
\hline Reduce emissions by around one-third & 42 & 44 & 41 & 44 & 47 & 43 \\
\hline $\begin{array}{l}\text { Benefit from an exemption (reduce emissions } \\
\text { by less than one-third) }\end{array}$ & 8 & 8 & 10 & 9 & 11 & 9 \\
\hline Total & 100 & 100 & 100 & 100 & 100 & 100 \\
\hline
\end{tabular}

What actions should research institutions and laboratories take to reduce their greenhouse gas emissions?

- Impose a cap on the number of flights per person

\begin{tabular}{rrrrrr}
$\begin{array}{r}\text { After the first } \\
\text { message }\end{array}$ & $\begin{array}{r}\text { After the first } \\
\text { reminder }\end{array}$ & $\begin{array}{r}\text { After the second } \\
\text { reminder }\end{array}$ & $\begin{array}{r}\text { After the third } \\
\text { reminder }\end{array}$ & $\begin{array}{r}\text { After the fourth } \\
\text { reminder }\end{array}$ \\
$\begin{aligned} \text { All } \\
56\end{aligned}$ & 54 & 53 & 51 & 51 & 54 \\
17 & 17 & 18 & 19 & 19 & 18 \\
21 & 22 & 20 & 24 & 23 & 22 \\
\hline 6 & 7 & 9 & 6 & 8 & 7 \\
100 & 100 & 100 & 100 & 100 & 100
\end{tabular}

- Add carbon emissions to the main selection criteria for project funding

\begin{tabular}{|c|c|c|c|c|c|}
\hline & $\begin{array}{r}\text { After the first } \\
\text { message }\end{array}$ & $\begin{array}{l}\text { After the first } \\
\text { reminder }\end{array}$ & $\begin{array}{r}\text { After the second } \\
\text { reminder }\end{array}$ & $\begin{array}{l}\text { After the third } \\
\text { reminder }\end{array}$ & $\begin{array}{r}\text { After the fourth } \\
\text { reminder }\end{array}$ \\
\hline It is a priority & 36 & 35 & 37 & 32 & 34 \\
\hline It is secondary & 30 & 31 & 29 & 31 & 32 \\
\hline $\begin{array}{l}\text { It should not be } \\
\text { implemented }\end{array}$ & 27 & 27 & 26 & 29 & 26 \\
\hline No opinion & 7 & 7 & 9 & 8 & 8 \\
\hline Total & 100 & 100 & 100 & 100 & 100 \\
\hline
\end{tabular}

- Reduce the importance of conferences and presentations abroad in career assessments 


\begin{tabular}{|c|c|c|c|c|c|c|}
\hline It is a priority & 64 & 62 & 63 & 57 & 56 & 61 \\
\hline It is secondary & 20 & 23 & 23 & 24 & 24 & 22 \\
\hline $\begin{array}{l}\text { It should not be } \\
\text { implemented }\end{array}$ & 8 & 7 & 8 & 12 & 12 & 9 \\
\hline No opinion & 8 & 8 & 6 & 7 & 8 & 8 \\
\hline Total & 100 & 100 & 100 & 100 & 100 & 100 \\
\hline
\end{tabular}

Linear regressions on the number of reminders sent before the questionnaire was completed: 


\section{$\begin{array}{llllll}\text { Model } 1 & \text { Model } 2 & \text { Model } 3 & \text { Model } 4 & \text { Model } 5 & \text { Model } 6\end{array}$}

$\begin{array}{llllllllllll}\text { Characteristic Beta } & \mathrm{SE}^{2} & \text { Beta }^{1} & \mathrm{SE}^{2} & \text { Beta }^{1} & \mathrm{SE}^{2} & \text { Beta }^{1} & \mathrm{SE}^{2} & \text { Beta }^{1} & \mathrm{SE}^{2} & \mathrm{Beta}^{1} & \mathrm{SE}^{2}\end{array}$

$\begin{array}{lllllllllllll}\text { (Intercept) } & 2.4^{* * *} & 0.053 & 2.3^{* * *} & 0.093 & 2.4^{* * *} & 0.096 & 2.2^{* * *} & 0.101 & 2.1^{* * *} & 0.112 & 2.4^{* * *} & 0.113\end{array}$

Sex

\begin{tabular}{lccccccccccccc} 
Man & - & - & - & - & - & - & - & - & - & - & - & - \\
Woman & $0.08^{*}$ & 0.037 & 0.06 & 0.039 & 0.06 & 0.040 & 0.07 & 0.042 & 0.05 & 0.043 & 0.04 & 0.042 \\
\hline Other & -0.28 & 0.419 & -0.30 & 0.419 & -0.32 & 0.419 & -0.31 & 0.432 & -0.22 & 0.432 & -0.29 & 0.430 \\
Age & & & & & & & & & & & &
\end{tabular}

50-54 years old

Under 29 years old $\quad-0.35^{* * *} \quad 0.066-0.43^{* * *} \quad 0.096-0.41^{* * *} \quad 0.097 \quad-0.45^{* * *} \quad 0.103-0.44^{* * *} 0.105 \quad-0.44^{* * *} 0.104$

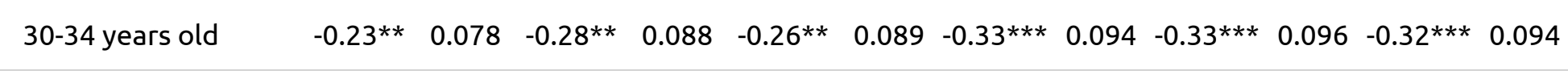

\begin{tabular}{lccccccccccccc} 
35-39 years old & $-0.20 * *$ & 0.073 & $-0.20 * *$ & 0.078 & $-0.19 *$ & 0.079 & $-0.23 * *$ & 0.082 & $-0.21 *$ & 0.085 & $-0.21^{*}$ & 0.083 \\
\hline 40-44 years old & -0.08 & 0.070 & -0.06 & 0.074 & -0.06 & 0.075 & -0.11 & 0.078 & -0.10 & 0.080 & -0.09 & 0.078 \\
45-49 years old & -0.06 & 0.071 & -0.05 & 0.074 & -0.03 & 0.075 & -0.11 & 0.078 & -0.09 & 0.080 & -0.08 & 0.078 \\
\hline $55-64$ years old & 0.08 & 0.068 & 0.07 & 0.071 & 0.09 & 0.071 & 0.04 & 0.075 & 0.05 & 0.077 & 0.05 & 0.076 \\
\hline 65 years and older & $0.34 * *$ & 0.112 & 0.21 & 0.117 & 0.21 & 0.120 & 0.21 & 0.126 & 0.20 & 0.131 & 0.24 & 0.128
\end{tabular}

\section{Status}

Associate Professor

Senior researcher

$\begin{array}{llllllllll}0.02 & 0.080 & 0.02 & 0.080 & 0.00 & 0.083 & -0.02 & 0.086 & -0.01 & 0.084\end{array}$

Full professor

$\begin{array}{llllllllll}0.12 & 0.079 & 0.10 & 0.080 & 0.04 & 0.084 & -0.02 & 0.086 & 0.04 & 0.084\end{array}$

Tenured researcher

$\begin{array}{llllllllll}-0.15^{*} & 0.071 & -0.15^{*} & 0.071 & -0.14 & 0.073 & -0.14 & 0.075 & -0.18^{*} & 0.074\end{array}$

Research engineer

$\begin{array}{llllllllll}-0.03 & 0.077 & -0.05 & 0.078 & -0.02 & 0.081 & -0.03 & 0.084 & -0.03 & 0.082\end{array}$

Postdoctoral

researcher

$\begin{array}{llllllllll}0.13 & 0.113 & 0.12 & 0.113 & 0.06 & 0.119 & 0.06 & 0.121 & 0.08 & 0.122\end{array}$

Adjunct lecturer

$\begin{array}{llllllllll}0.27 & 0.194 & 0.23 & 0.197 & 0.33 & 0.206 & 0.36 & 0.208 & 0.29 & 0.205\end{array}$

Fully funded PhD student

$\begin{array}{llllllllll}0.06 & 0.098 & 0.04 & 0.099 & 0.06 & 0.104 & 0.04 & 0.106 & 0.03 & 0.106\end{array}$

Research support engineer

$\begin{array}{llllllllll}-0.13 & 0.079 & -0.16^{*} & 0.080 & -0.18^{*} & 0.083 & -0.19^{*} & 0.085 & -0.18^{*} & 0.083\end{array}$

Research

assistant/Project

manager

$\begin{array}{llllllllll}0.17 & 0.237 & 0.30 & 0.246 & 0.45 & 0.251 & 0.35 & 0.254 & 0.42 & 0.257\end{array}$

Engineer assistant

$\begin{array}{llll}-0.12 & 0.102 & -0.15 & 0.104\end{array}$

$-0.14$

0.108

$-0.10$

0.114

$-0.13 \quad 0.110$

\footnotetext{
$1 * \mathrm{p}<0.05 ; * * \mathrm{p}<0.01 ; * * * \mathrm{p}<0.001$

${ }^{2} \mathrm{SE}=$ Standard Error
} 


\section{$\begin{array}{llllll}\text { Model } 1 & \text { Model } 2 & \text { Model } 3 & \text { Model } 4 & \text { Model } 5 & \text { Model } 6\end{array}$}

\begin{tabular}{|c|c|c|c|c|c|c|c|c|c|c|c|c|}
\hline \multirow[b]{2}{*}{ Characteristic } & \multirow{2}{*}{ Beta ${ }^{1}$} & \multirow[b]{2}{*}{$\mathrm{SE}^{2}$} & \multirow[b]{2}{*}{ Beta ${ }^{1}$} & \multirow[b]{2}{*}{$\mathrm{SE}^{2}$} & & \multirow[b]{2}{*}{ Beta $^{1}$} & \multirow[b]{2}{*}{$\mathbf{S E}^{2}$} & & \\
\hline & & & & & Beta ${ }^{1}$ & $\mathrm{SE}^{2}$ & & & Beta ${ }^{1}$ & $\mathrm{SE}^{2}$ & Beta ${ }^{1}$ & $\mathrm{SE}^{2}$ \\
\hline Technician & & & 0.06 & 0.117 & 0.09 & 0.120 & 0.14 & 0.127 & 0.14 & 0.135 & 0.11 & 0.130 \\
\hline Technical assistant & & & 0.03 & 0.288 & 0.15 & 0.299 & 0.45 & 0.341 & 0.46 & 0.341 & 0.46 & 0.360 \\
\hline Other personne & & & $0.33 * *$ & 0.100 & $0.40 * * *$ & 0.103 & $0.43^{* * *}$ & 0.111 & $0.44^{* * *}$ & 0.114 & $0.41 * * *$ & 0.113 \\
\hline
\end{tabular}

\section{Discipline}

\section{Physics}

Law, economics, management
0.110 .100
$0.15 \quad 0.101$
0.21
$0.1050 .22 *$
$0.108 \quad 0.23 * 0.106$

Other humanities and social sciences

$\begin{array}{llllllllll}0.11 & 0.092 & 0.12 & 0.092 & 0.18 & 0.097 & 0.20 * & 0.100 & 0.23 * & 0.097\end{array}$

History, geography,

urbanism,

$\begin{array}{llllllllll}0.18 * & 0.091 & 0.17 & 0.092 & 0.21 * & 0.096 & 0.22 * & 0.098 & 0.22 * & 0.097\end{array}$

anthropology

\begin{tabular}{|c|c|c|c|c|c|c|c|c|c|c|}
\hline Mathematics & -0.09 & 0.100 & -0.09 & 0.101 & -0.04 & 0.106 & -0.05 & 0.108 & -0.03 & 0.107 \\
\hline Computer science & -0.10 & 0.097 & -0.08 & 0.097 & -0.04 & 0.101 & -0.02 & 0.103 & -0.03 & 0.101 \\
\hline Chemistry & 0.04 & 0.085 & 0.02 & 0.085 & 0.07 & 0.090 & 0.03 & 0.092 & 0.08 & 0.090 \\
\hline Astronomy & -0.04 & 0.112 & 0.00 & 0.113 & 0.05 & 0.117 & 0.11 & 0.120 & 0.07 & 0.117 \\
\hline Geology & -0.11 & 0.114 & -0.10 & 0.114 & -0.08 & 0.117 & -0.06 & 0.120 & -0.05 & 0.118 \\
\hline $\begin{array}{l}\text { Meteorology, } \\
\text { oceanology, } \\
\text { environmental } \\
\text { physics }\end{array}$ & -0.11 & 0.119 & -0.09 & 0.120 & -0.07 & 0.125 & -0.01 & 0.127 & -0.05 & 0.126 \\
\hline
\end{tabular}

Health and medical research

$\begin{array}{llllllllll}0.13 & 0.088 & 0.15 & 0.089 & 0.25 * * & 0.094 & 0.23^{*} & 0.096 & 0.22 * & 0.094\end{array}$

$\begin{array}{lcccccccccc}\text { Engineering } & 0.11 & 0.084 & 0.13 & 0.084 & 0.15 & 0.088 & 0.15 & 0.090 & 0.17 & 0.088 \\ \text { Biology } & 0.13 & 0.089 & 0.14 & 0.090 & 0.16 & 0.094 & 0.17 & 0.096 & 0.22^{*} & 0.094 \\ \begin{array}{l}\text { Population biology } \\ \text { and ecology }\end{array} & 0.11 & 0.116 & 0.14 & 0.117 & 0.17 & 0.122 & 0.18 & 0.125 & 0.17 & 0.123\end{array}$

Degree of concern

about climate

change

Very concerned

Not at all concerned

$-0.10 \quad 0.247$

$0.08 \quad 0.343$

Slightly concerned

$-0.06 \quad 0.085$

$-0.12 \quad 0.104$

${ }^{1 *} \mathrm{p}<0.05 ;{ }^{* *} \mathrm{p}<0.01 ;{ }^{* * *} \mathrm{p}<0.001$

${ }^{2} \mathrm{SE}=$ Standard Error 


\begin{tabular}{|c|c|c|c|c|c|c|c|c|c|c|c|c|}
\hline \multirow[b]{2}{*}{ Characteristic } & \multicolumn{2}{|c|}{ Model 1} & \multicolumn{2}{|c|}{ Model 2} & \multicolumn{2}{|c|}{ Model 3} & \multicolumn{2}{|c|}{ Model 4} & \multicolumn{2}{|c|}{ Model 5} & \multicolumn{2}{|c|}{ Model 6} \\
\hline & Beta ${ }^{1}$ & $\mathrm{SE}^{2}$ & Beta ${ }^{1}$ & $\mathrm{SE}^{2}$ & Beta ${ }^{1}$ & $\mathrm{SE}^{2}$ & Beta ${ }^{1}$ & $\mathrm{SE}^{2}$ & Beta $^{1}$ & $\mathrm{SE}^{2}$ & Beta ${ }^{1}$ & $\mathrm{SE}^{2}$ \\
\hline $\begin{array}{l}\text { Somewhat } \\
\text { concerned }\end{array}$ & & & & & -0.03 & 0.051 & & & -0.09 & 0.058 & & \\
\hline $\begin{array}{l}\text { Extremely } \\
\text { concerned }\end{array}$ & & & & & $-0.14 * *$ & 0.045 & & & -0.04 & 0.050 & & \\
\hline No opinion & & & & & -0.11 & 0.325 & & & -0.28 & 0.403 & & \\
\hline
\end{tabular}

\section{Desirable GHGs}

emission reduction

target for public

research by 2030

Set an example

(reduce emissions by

more than one-third)

Reduce emissions by

around one-third

$0.10 * \quad 0.041$

Benefit from an exemption (reduce emissions by less

than one-third)

\section{A major ecological catastrophe is going \\ to occur}

Completely agree

Somewhat agree

$0.13^{*} \quad 0.050$

Somewhat disagree

$0.11 \quad 0.125$

Completely disagree

$\begin{array}{ll}-0.30 & 0.208\end{array}$

No opinion

$0.14 \quad 0.109$

\section{Regulatory}

constraints to

protect the

environment

\section{Completely agree}

Somewhat agree

$0.02 \quad 0.048$

Somewhat disagree

$-0.09 \quad 0.090$

Completely disagree

$-0.19 \quad 0.144$

No opinion

$0.12 \quad 0.159$

${ }^{*} \mathrm{p}<0.05 ;{ }^{* *} \mathrm{p}<0.01 ;{ }^{* * *} \mathrm{p}<0.001$

${ }^{2} \mathrm{SE}=$ Standard Error 


\section{Characteristic \\ Protecting the \\ environment is more \\ important than \\ protecting economic \\ growth}

Model 1

Model 2

Model 3

Model 4

Model 5

Model 6

Completely agree

Somewhat agree

$0.11 * \quad 0.049$

Somewhat disagree

$0.07 \quad 0.092$

Completely disagree

$0.08 \quad 0.182$

No opinion

$0.13 \quad 0.132$

\section{Desirable GHG}

emission reduction

target for public

research by 2030

Set an example

(reduce emissions by

more than one-third)

Reduce emissions by

around one-third

$0.06 \quad 0.045$

Benefit from an exemption (reduce emissions by less

than one-third)

\section{Impose a cap on the}

number of flights

per person

It is a priority

It is secondary

$0.04 \quad 0.057$

It should not be

implemented

$0.00 \quad 0.057$

No opinion

$0.04 \quad 0.093$

\section{Add carbon}

emissions to the

main selection

criteria for project

funding

It is a priority

It is secondary

$0.03 \quad 0.052$

\footnotetext{
${ }^{1 *} \mathrm{p}<0.05 ;{ }^{* *} \mathrm{p}<0.01 ; * * * \mathrm{p}<0.001$

${ }^{2} \mathrm{SE}=$ Standard Error
} 


$\begin{array}{llllll}\text { Model } 1 & \text { Model } 2 & \text { Model } 3 & \text { Model } 4 & \text { Model } 5 & \text { Model } 6\end{array}$

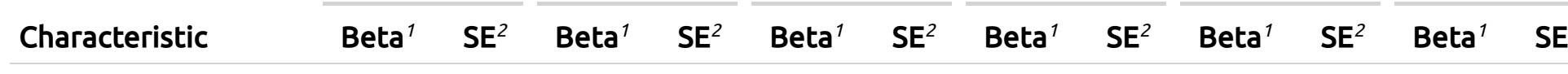

It should not be

implemented

$-0.020 .058$

No opinion

$0.06 \quad 0.090$

Reduce the

importance of

conferences and

presentations

abroad in career

assessments

It is a priority

It is secondary

$0.12 * \quad 0.051$

It should not be

implemented

\section{$0.24 * * \quad 0.077$}

No opinion

$-0.04 \quad 0.088$

\section{Being in a moment}

in one's career in

which one is seeking

to be promoted,

recruited or tenured

No

Yes

\section{Feeling underpaid}

No

Yes

$0.07 \quad 0.043$

\section{Born abroad}

Yes

No

$-0.14^{*} \quad 0.060$

\begin{tabular}{lllllll}
\hline No. Obs. & 6,429 & 6,065 & 5,926 & 5,318 & 5,051 & 5,212 \\
\hline $\mathrm{R}^{2}$ & 0.014 & 0.025 & 0.028 & 0.031 & 0.041 & 0.032 \\
\hline Adjusted $\mathrm{R}^{2}$ & 0.012 & 0.019 & 0.021 & 0.024 & 0.029 & 0.025 \\
\hline
\end{tabular}

${ }^{1} \mathrm{p}<0.05 ;{ }^{* *} \mathrm{p}<0.01 ;{ }^{* * *} \mathrm{p}<0.001$

${ }^{2} \mathrm{SE}=$ Standard Error 


\section{Opinions}

.

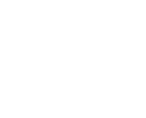

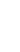

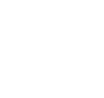

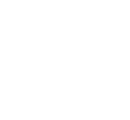

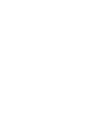

.

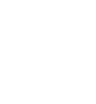

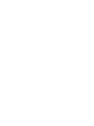

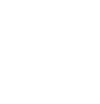

.

.




\subsection{Overview}

Opinions of respondents on a selection of questions by discipline et status (\%) :

\begin{tabular}{|c|c|c|c|c|c|c|c|c|}
\hline & $\begin{array}{r}\text { Climate } \\
\text { is } \\
\text { definitely } \\
\text { changing }\end{array}$ & $\begin{array}{r}\text { Very or } \\
\text { extremely } \\
\text { concerned }\end{array}$ & $\begin{array}{r}\text { Much } \\
\text { more } \\
\text { concerned } \\
\text { than } 5 \\
\text { years ago }\end{array}$ & $\begin{array}{r}\text { Human } \\
\text { activites } \\
\text { cause } \\
\text { climate } \\
\text { change }\end{array}$ & $\begin{array}{r}\text { Calls for } \\
\text { profound } \\
\text { changes in our } \\
\text { professions }\end{array}$ & $\begin{array}{r}\text { We will soon } \\
\text { experience an } \\
\text { ecological } \\
\text { catastrophe }\end{array}$ & $\begin{array}{r}\text { It could } \\
\text { cause a } \\
\text { collapse of } \\
\text { our societies }\end{array}$ & $\begin{array}{r}\text { Research must } \\
\text { reduce its } \\
\text { emissions by more } \\
\text { than one-third }\end{array}$ \\
\hline $\begin{array}{l}\text { Law, } \\
\text { economics, } \\
\text { management }\end{array}$ & 92 & 71 & 50 & 95 & 90 & 91 & 74 & 58 \\
\hline $\begin{array}{l}\text { Other } \\
\text { humanities and } \\
\text { social sciences }\end{array}$ & 90 & 75 & 46 & 97 & 86 & 91 & 72 & 53 \\
\hline $\begin{array}{l}\text { History, } \\
\text { geography, } \\
\text { urbanism, } \\
\text { anthropology }\end{array}$ & 92 & 74 & 45 & 95 & 88 & 90 & 75 & 50 \\
\hline Mathematics & 92 & 72 & 45 & 96 & 81 & 89 & 69 & 51 \\
\hline $\begin{array}{l}\text { Computer } \\
\text { science }\end{array}$ & 89 & 72 & 42 & 97 & 90 & 92 & 70 & 53 \\
\hline Physics & 90 & 73 & 41 & 96 & 83 & 87 & 74 & 39 \\
\hline Chemistry & 88 & 67 & 45 & 96 & 87 & 88 & 73 & 42 \\
\hline Astronomy & 95 & 76 & 41 & 99 & 89 & 91 & 71 & 50 \\
\hline Geology & 92 & 74 & 40 & 97 & 90 & 89 & 68 & 41 \\
\hline $\begin{array}{l}\text { Meteorology, } \\
\text { oceanology, } \\
\text { environmental } \\
\text { physics }\end{array}$ & 95 & 84 & 39 & 99 & 96 & 95 & 80 & 52 \\
\hline $\begin{array}{l}\text { Health and } \\
\text { medical } \\
\text { research }\end{array}$ & 93 & 67 & 50 & 96 & 90 & 94 & 79 & 42 \\
\hline Engineering & 90 & 70 & 47 & 96 & 88 & 89 & 75 & 52 \\
\hline Biology & 88 & 70 & 44 & 96 & 90 & 92 & 77 & 43 \\
\hline $\begin{array}{l}\text { Population } \\
\text { biology and } \\
\text { ecology }\end{array}$ & 95 & 83 & 42 & 97 & 93 & 95 & 81 & 54 \\
\hline All & 91 & 72 & 45 & 96 & 88 & 90 & 74 & 48 \\
\hline
\end{tabular}


Human Calls for activites profound cause changes in climate change
Much more

concerned

than 5

years ago
We will soon

experience an

ecological

collapse of

professions
Research must reduce its

emissions by more than onethird

\begin{tabular}{|c|c|c|c|c|c|c|c|c|}
\hline $\begin{array}{l}\text { Senior } \\
\text { researcher }\end{array}$ & 90 & 76 & 47 & 95 & 83 & 88 & 69 & 38 \\
\hline Full professor & 89 & 71 & 44 & 94 & 80 & 84 & 68 & 42 \\
\hline $\begin{array}{l}\text { Tenured } \\
\text { researcher }\end{array}$ & 92 & 77 & 44 & 96 & 88 & 92 & 76 & 44 \\
\hline $\begin{array}{l}\text { Associate } \\
\text { professor }\end{array}$ & 90 & 74 & 42 & 96 & 86 & 90 & 74 & 48 \\
\hline $\begin{array}{l}\text { Research } \\
\text { engineer }\end{array}$ & 90 & 70 & 41 & 96 & 90 & 90 & 74 & 47 \\
\hline $\begin{array}{l}\text { Postdoctoral } \\
\text { researcher }\end{array}$ & 93 & 75 & 45 & 98 & 92 & 96 & 75 & 49 \\
\hline Adjunct lecturer & 95 & 76 & 42 & 100 & 87 & 95 & 75 & 56 \\
\hline $\begin{array}{l}\text { Fully funded } \\
\text { PhD student }\end{array}$ & 95 & 75 & 53 & 98 & 92 & 94 & 76 & 52 \\
\hline $\begin{array}{l}\text { Research } \\
\text { support } \\
\text { engineer }\end{array}$ & 90 & 65 & 41 & 96 & 94 & 90 & 76 & 56 \\
\hline $\begin{array}{l}\text { Research } \\
\text { assistant/Project } \\
\text { manager }\end{array}$ & 92 & 74 & 53 & 100 & 97 & 94 & 66 & 51 \\
\hline $\begin{array}{l}\text { Engineer } \\
\text { assistant }\end{array}$ & 87 & 62 & 40 & 94 & 93 & 88 & 79 & 53 \\
\hline Technician & 86 & 53 & 44 & 95 & 93 & 88 & 74 & 54 \\
\hline $\begin{array}{l}\text { Technical } \\
\text { assistant }\end{array}$ & 80 & 37 & 44 & 90 & 88 & 80 & 70 & 33 \\
\hline Other personnel & 93 & 70 & 45 & 95 & 86 & 90 & 75 & 54 \\
\hline All & 91 & 71 & 45 & 96 & 88 & 90 & 74 & 48 \\
\hline
\end{tabular}




\subsection{Human activities and climate change}

Are human activities the cause of climate change

(rise in temperatures in the last century)?

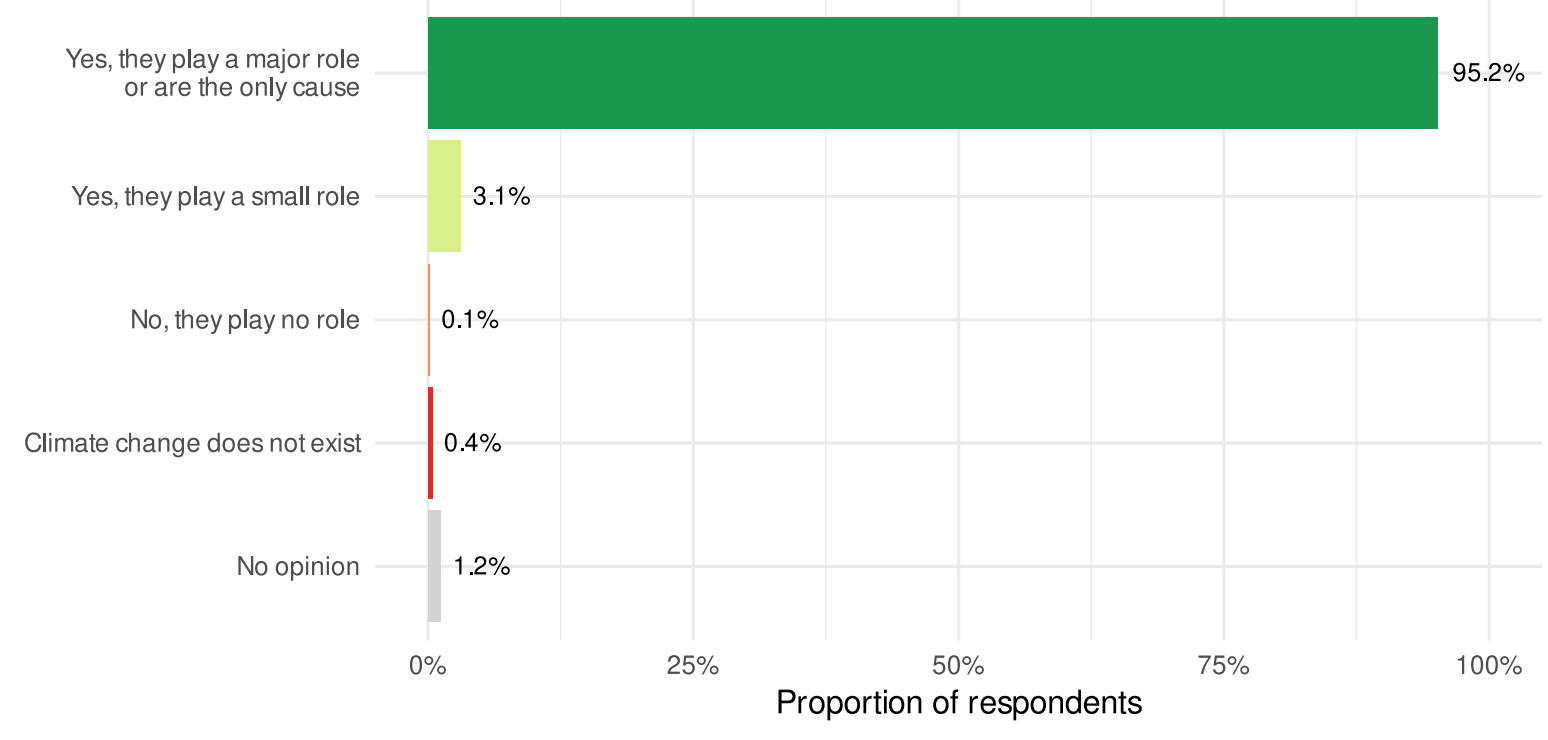

For $95.1 \%$ of respondents, human activities play a major role or are the only cause of climate change. Source: "Research personnel and climate change" survey, Labos 1point5, 2020

Coverage: personnel affiliated with a CNRS unit $(n=6337)$

\begin{tabular}{lrr} 
& $\mathbf{n}$ & val\% \\
\hline Yes, they are the only cause & 1159 & 17.9 \\
\hline Yes, they play a major role & 4871 & 75.3 \\
\hline Yes, they play a small role & 197 & 3.0 \\
\hline No, they play no role & 9.1 \\
\hline Climate change does not exist & 0.1 \\
\hline No opinion & 24 & 0.4 \\
\hline NA & 76.4 & 1.2 \\
\hline
\end{tabular}


Law, economics, management

Other humanities and social

94

sciences

History, geography, urbanism, anthropology

Mathematics

Computer science

96

94

94

Physics

Chemistry

Astronomy

Geology

Meteorology, oceanology,

environmental physics

Health and medical research

Engineering

Biology

Population biology and ecology

All

$\begin{array}{lll}4 & 4 \\ 6 & 2 \\ 4 & 4 \\ 4 & 2 \\ 9 & 2 \\ 95 & 3 \\ 95 & 4 \\ 95 & 1 \\ 9 & 2 & 0 \\ 95 & 0 & 0\end{array}$

1100

0

$\begin{array}{lll}0 & 1 & 100\end{array}$

0

1100

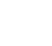

0

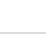

0

0

0

0

0

$\begin{array}{llllll}95 & 3 & 0 & 0 & 1 & 100 \\ 95 & 4 & 0 & 0 & 1 & 100 \\ 95 & 4 & 0 & 0 & 1 & 100 \\ 97 & 2 & 0 & 0 & 0 & 100 \\ 95 & 3 & 0 & 0 & 1 & 100\end{array}$

Yes, they play a major role or are the only cause
Yes, they play a small role
No, they play no role
Climate change No does not exist opinion Total
Senior researcher

Full professor

Tenured researcher

Associate professor

Research engineer

Postdoctoral researcher

Adjunct lecturer

Fully funded PhD

student

Research support

engineer

Research

assistant/Project

manager

Engineer assistant

Technician

Technical assistant

Other personnel

All

$\begin{array}{lll}95 & 3 & 0 \\ 92 & 4 & 0 \\ 96 & 3 & 0 \\ 95 & 3 & 0 \\ 95 & 3 & 0 \\ 98 & 2 & 0 \\ 100 & 0 & 0 \\ 97 & 2 & 0 \\ 95 & 3 & 0 \\ 100 & 0 & 0\end{array}$

\section{0}

0

0

0

0

0

0

$\begin{array}{lll}0 & 1 & 100\end{array}$

13100

$\begin{array}{lll}0 & 1 & 100\end{array}$

$\begin{array}{lll}0 & 1 & 100\end{array}$

$\begin{array}{lll}0 & 1 & 100\end{array}$

$0 \quad 0 \quad 100$

$\begin{array}{lll}0 & 0 & 100\end{array}$

$\begin{array}{lll}0 & 1 & 100\end{array}$

0

$\begin{array}{lll}0 & 1 & 100\end{array}$

0

$\begin{array}{lll}0 & 0 & 100\end{array}$ 


\subsection{Concern about climate change}

To what degree are you concerned about climate change?

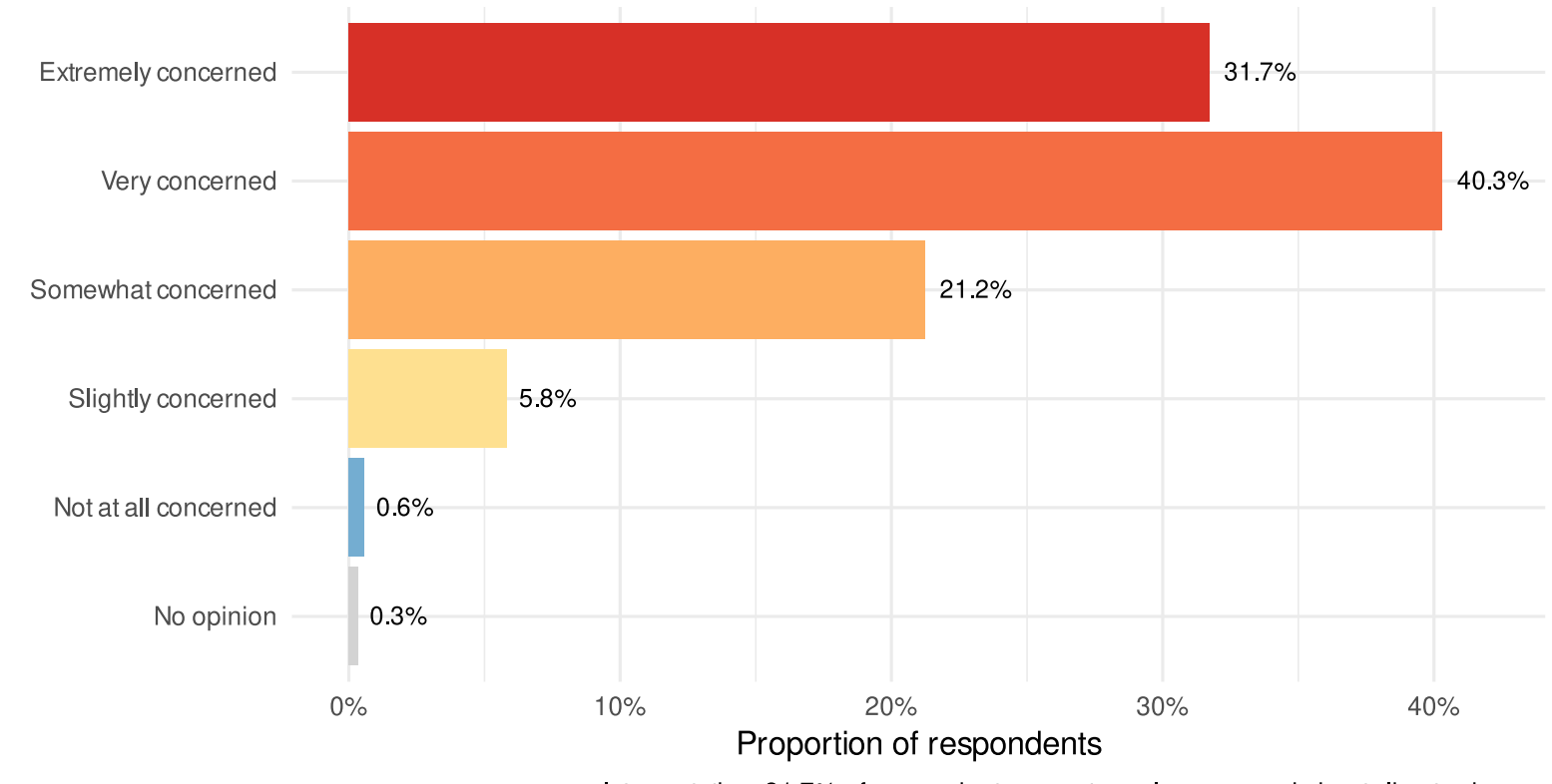

Interpretation: $31.7 \%$ of respondents are extremely concerned about climate change Source: "Research personnel and climate change" survey, Labos 1point5, 2020

Coverage: personnel affiliated with a CNRS unit $(n=6287)$

\begin{tabular}{lrrr} 
& $\mathbf{n}$ & $\mathbf{\%}$ & val\% \\
\hline Not at all concerned & 60 & 0.9 & 0.9 \\
\hline Slightly concerned & 367 & 5.7 & 5.8 \\
Somewhat concerned & 1335 & 20.6 & 21.1 \\
\hline Very concerned & 2534 & 39.2 & 40.0 \\
\hline Extremely concerned & 1994 & 30.8 & 31.4 \\
\hline No opinion & 52 & 0.8 & 0.8 \\
\hline NA & 125 & 1.9 & NA
\end{tabular}




\section{2}

Law, economics, management

Other humanities and social sciences

History, geography, urbanism, anthropology

Mathematics

Computer science

Physics

Chemistry

Astronomy

Geology

Meteorology, oceanology,

environmental physics

Health and medical research

Engineering

Biology

Population biology and ecology

All

1
1
1

2

7

24

1

5

17

1
2
1

5

19

113

13

$7 \quad 24$

22

24

13

21

6

$\begin{array}{lll}6 & 22 & 36 \\ 4 & 19 & 39 \\ 4 & 21 & 37\end{array}$

concerned

opinion Total

\section{6}

39

\section{7}

$\begin{array}{llll}1 & 7 & 19 & 43\end{array}$

42

$\begin{array}{llll}1 & 7 & 19 & 42 \\ 2 & 6 & 18 & 39\end{array}$

39

44

39

35

40

35

$0 \quad 100$

$24 \quad 40$

39

40

41

40

Slightly

Not at all concerned concerned

Somewhat concerned

Very concerned

Extremely No concerned opinion Total

\section{Senior researcher}

$1 \quad 5$

Full professor

26

Tenured researcher

$0 \quad 5$

Associate professor

Research engineer

Postdoctoral researcher

Adjunct lecturer

Fully funded PhD student

Research support engineer

Research assistant/Project

manager

$$
\begin{aligned}
& \text { En } \\
& \text { Te } \\
& \text { Te } \\
& \text { Ot } \\
& \text { All }
\end{aligned}
$$

Engineer assistant

Technician

$1 \quad 5$

5

$1 \quad 7$

15

0

0

$1 \quad 5$

1

0

5
7
0

18

$17 \quad 39$

Technical assistant

$\begin{array}{rrr}1 & 11 & 26 \\ 0 & 8 & 36 \\ 2 & 12 & 49 \\ 1 & 7 & 22 \\ 1 & 6 & 21\end{array}$

$\begin{array}{ll}26 & 41 \\ 36 & 32 \\ 49 & 27 \\ 22 & 37 \\ 21 & 40\end{array}$

38

37

$\begin{array}{lll}37 & 1 & 100\end{array}$

$33 \quad 2 \quad 100$

$\begin{array}{lll}37 & 1 & 100\end{array}$

$20 \quad 39$

$22 \quad 43$

$39 \quad 35$

$19 \quad 40$

$23 \quad 48$

$18 \quad 42$

$27 \quad 42$

$26 \quad 42$

$\begin{array}{lll}35 & 1 & 100\end{array}$

$27 \quad 1 \quad 100$

$\begin{array}{llll}40 & 35 & 0 & 100\end{array}$

$\begin{array}{llll}48 & 27 & 2 & 100\end{array}$

$\begin{array}{llll}42 & 33 & 1 & 100\end{array}$

\begin{tabular}{llll}
42 & 23 & 1 & 100 \\
\hline 42 & 32 & 0 & 100
\end{tabular}

$\begin{array}{llll}41 & 21 & 1 & 100 \\ 32 & 21 & 2 & 100 \\ 27 & 10 & 0 & 100 \\ 37 & 33 & 1 & 100 \\ 40 & 31 & 1 & 100\end{array}$




\subsection{Change in degree of concern}

Are you more or less concerned about climate change than 5 years ago?

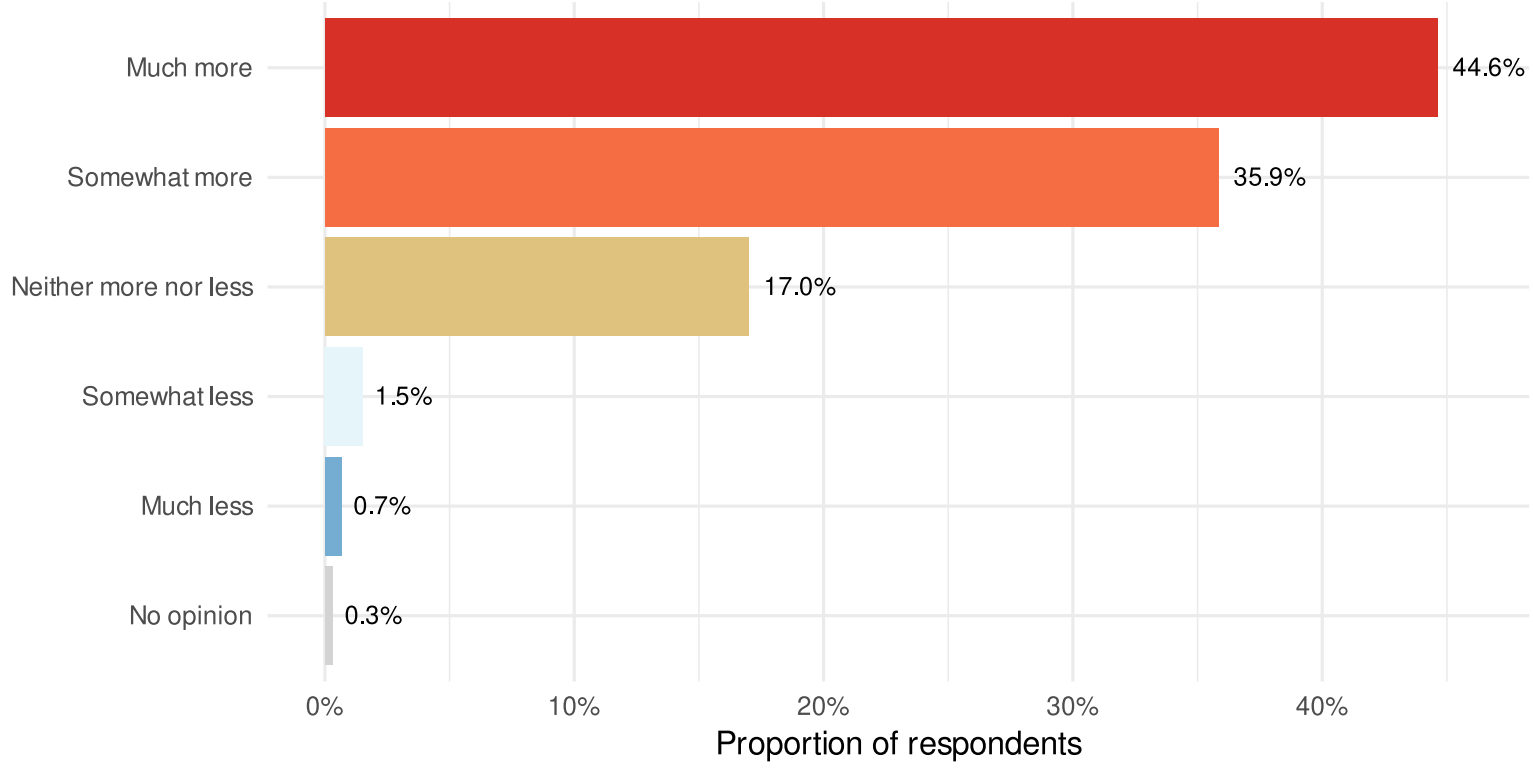

Interpretation: $44.6 \%$ of respondents are much more concerned about climate change than 5 years ago Source: "Research personnel and climate change" survey, Labos 1point5, 2020 Coverage: personnel affiliated with a CNRS unit $(n=6287)$

\section{Much more}

Somewhat more

Neither more nor less

Somewhat less

Much less

No opinion

NA

\begin{tabular}{rrr}
$\mathbf{n}$ & \% & val\% \\
\hline 2806 & 43.4 & 44.6 \\
2254 & 34.9 & 35.9 \\
1069 & 16.5 & 17.0 \\
96 & 1.5 & 1.5 \\
42 & 0.6 & 0.7 \\
20 & 0.3 & 0.3 \\
180 & 2.8 & NA
\end{tabular}

\begin{tabular}{|c|c|c|c|c|c|c|c|}
\hline & $\begin{array}{l}\text { Much } \\
\text { more }\end{array}$ & $\begin{array}{r}\text { Somewhat } \\
\text { more }\end{array}$ & $\begin{array}{r}\text { Neither more nor } \\
\text { less }\end{array}$ & $\begin{array}{r}\text { Somewhat } \\
\text { less }\end{array}$ & $\begin{array}{r}\text { Much } \\
\text { less }\end{array}$ & $\begin{array}{r}\text { No } \\
\text { opinion }\end{array}$ & Total \\
\hline Law, economics, management & 50 & 34 & 14 & 1 & 1 & 0 & 100 \\
\hline Other humanities and social sciences & 46 & 37 & 14 & 2 & 1 & 0 & 100 \\
\hline History, geography, urbanism, anthropology & 45 & 36 & 17 & 1 & 1 & 0 & 100 \\
\hline Mathematics & 45 & 36 & 17 & 1 & 1 & 1 & 100 \\
\hline Computer science & 42 & 39 & 18 & 1 & 1 & 0 & 100 \\
\hline Physics & 41 & 36 & 20 & 2 & 1 & 1 & 100 \\
\hline Chemistry & 45 & 38 & 15 & 1 & 1 & 1 & 100 \\
\hline Astronomy & 41 & 37 & 20 & 1 & 0 & 0 & 100 \\
\hline Geology & 40 & 36 & 23 & 1 & 0 & 0 & 100 \\
\hline $\begin{array}{l}\text { Meteorology, oceanology, environmental } \\
\text { physics }\end{array}$ & 39 & 31 & 27 & 3 & 1 & 0 & 100 \\
\hline Health and medical research & 50 & 31 & 16 & 2 & 1 & 0 & 100 \\
\hline Engineering & 47 & 33 & 18 & 1 & 1 & 0 & 100 \\
\hline Biology & 44 & 40 & 13 & 1 & 1 & 0 & 100 \\
\hline Population biology and ecology & 42 & 36 & 19 & 2 & 1 & 0 & 100 \\
\hline All & 45 & 36 & 17 & 1 & 1 & 0 & 100 \\
\hline
\end{tabular}




\begin{tabular}{|c|c|c|c|c|c|c|c|}
\hline & $\begin{array}{l}\text { Much } \\
\text { more }\end{array}$ & $\begin{array}{r}\text { Somewhat } \\
\text { more }\end{array}$ & Neither more nor less & $\begin{array}{r}\text { Somewhat } \\
\text { less }\end{array}$ & $\begin{array}{r}\text { Much } \\
\text { less }\end{array}$ & $\begin{array}{r}\text { No } \\
\text { opinion }\end{array}$ & Total \\
\hline Senior researcher & 47 & 32 & 20 & 0 & 0 & 0 & 100 \\
\hline Full professor & 44 & 32 & 22 & 1 & 1 & 0 & 100 \\
\hline Tenured researcher & 44 & 36 & 17 & 1 & 1 & 0 & 100 \\
\hline Associate professor & 42 & 38 & 19 & 1 & 0 & 0 & 100 \\
\hline Research engineer & 41 & 39 & 19 & 1 & 0 & 0 & 100 \\
\hline Postdoctoral researcher & 45 & 36 & 13 & 3 & 2 & 0 & 100 \\
\hline Adjunct lecturer & 42 & 34 & 19 & 5 & 0 & 0 & 100 \\
\hline Fully funded PhD student & 53 & 33 & 10 & 2 & 1 & 1 & 100 \\
\hline Research support engineer & 41 & 39 & 17 & 2 & 1 & 0 & 100 \\
\hline Research assistant/Project manager & 53 & 32 & 11 & 5 & 0 & 0 & 100 \\
\hline Engineer assistant & 40 & 40 & 18 & 2 & 0 & 0 & 100 \\
\hline Technician & 44 & 38 & 14 & 3 & 0 & 0 & 100 \\
\hline Technical assistant & 44 & 41 & 10 & 5 & 0 & 0 & 100 \\
\hline Other personnel & 45 & 36 & 16 & 2 & 0 & 0 & 100 \\
\hline All & 45 & 36 & 17 & 2 & 1 & 0 & 100 \\
\hline
\end{tabular}




\subsection{Opinions on ecology in general}

\begin{tabular}{|c|c|c|c|c|c|c|}
\hline & $\begin{array}{r}\text { Completely } \\
\text { agree }\end{array}$ & $\begin{array}{r}\text { Somewhat } \\
\text { agree }\end{array}$ & $\begin{array}{r}\text { No } \\
\text { opinion }\end{array}$ & $\begin{array}{r}\text { Somewhat } \\
\text { disagree }\end{array}$ & $\begin{array}{r}\text { Completely } \\
\text { disagree }\end{array}$ & Total \\
\hline $\begin{array}{l}\text { If things continue on their present course, we will soon experience a } \\
\text { major ecological catastrophe }\end{array}$ & 59 & 31 & 5 & 3 & 2 & 100 \\
\hline This type of catastrophe could cause a collapse of our societies* & 36 & 38 & 11 & 9 & 6 & 100 \\
\hline $\begin{array}{l}\text { Protecting the environment is more important than protecting } \\
\text { economic growth }\end{array}$ & 55 & 33 & 3 & 7 & 2 & 100 \\
\hline $\begin{array}{l}\text { I agree with having regulatory constraints put in place to protect the } \\
\text { environment, even if it limits my comfort }\end{array}$ & 45 & 42 & 2 & 8 & 3 & 100 \\
\hline Degrowth is necessary to face environmental challenges & 34 & 31 & 12 & 15 & 8 & 100 \\
\hline $\begin{array}{l}\text { Most environmental problems can be solved by applying more and } \\
\text { better technology }\end{array}$ & 10 & 36 & 5 & 35 & 13 & 100 \\
\hline $\begin{array}{l}\text { There is no point in me making an effort for the environment if } \\
\text { others do not do the same }\end{array}$ & 4 & 13 & 2 & 36 & 45 & 100 \\
\hline
\end{tabular}

* Respondents disagreeing with previous question are classified as "Strongly disagree".

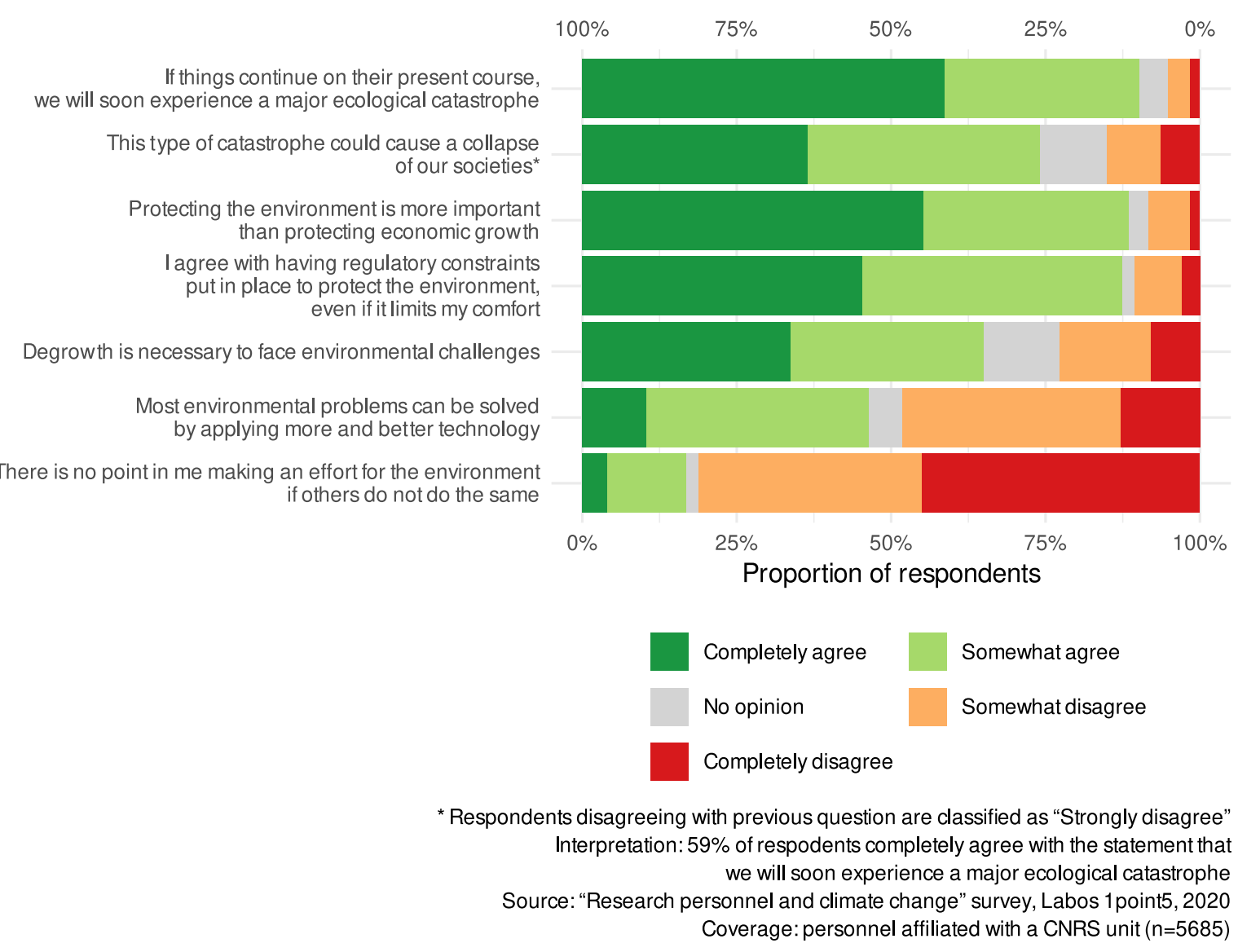

If things continue on their present course, we will soon experience a major ecological catastrophe

\begin{tabular}{lrrr} 
& $\mathbf{n}$ & \% & val\% \\
\hline Completely agree & 3337 & 51.6 & 58.7 \\
\hline Somewhat agree & 1788 & 27.6 & 31.5 \\
\hline Somewhat disagree & 198 & 3.1 & 3.5 \\
\hline Completely disagree & 97 & 1.5 & 1.7 \\
\hline No opinion & 265 & 4.1 & 4.7 \\
\hline NA & 782 & 12.1 & NA
\end{tabular}


Law, economics, management

Other humanities and social sciences

History, geography, urbanism, anthropology

Mathematics

Computer science

Physics

Chemistry

Astronomy

Geology

Meteorology, oceanology, environmental

physics

Health and medical research

Engineering

Biology

Population biology and ecology

All

59

64

61

55

62

57

54

65

58

68

$\begin{array}{ll}59 & 35 \\ 56 & 33 \\ 55 & 36 \\ 66 & 29 \\ 59 & 31\end{array}$

\section{2}

27

29

33

29

30

34

26

31

27

27

35

33

36

29

31

3

2

5100

7

2

1

5100

$3 \quad 5 \quad 100$

\begin{tabular}{cccc}
4 & 3 & 5 & 100 \\
3 & 1 & 5 & 100 \\
\hline
\end{tabular}

\begin{tabular}{lrrrrrr} 
& $\begin{array}{r}\text { Completely } \\
\text { agree }\end{array}$ & $\begin{array}{r}\text { Somewhat } \\
\text { agree }\end{array}$ & $\begin{array}{r}\text { Somewhat } \\
\text { disagree }\end{array}$ & $\begin{array}{r}\text { Completely } \\
\text { disagree }\end{array}$ & $\begin{array}{r}\text { No } \\
\text { opinion }\end{array}$ & $\begin{array}{r}\text { Total } \\
\text { Senior researcher }\end{array}$ \\
\hline Full professor & 48 & 35 & 36 & 5 & 4 & 100 \\
\hline Tenured researcher & 59 & 33 & 4 & 1 & 4 & 100 \\
\hline Associate professor & 62 & 29 & 3 & 2 & 4 & 100 \\
\hline Research engineer & 57 & 33 & 3 & 2 & 5 & 100 \\
\hline Postdoctoral researcher & 66 & 30 & 2 & 0 & 1 & 100 \\
\hline Adjunct lecturer & 59 & 36 & 0 & 0 & 5 & 100 \\
\hline Fully funded PhD student & 68 & 25 & 1 & 1 & 4 & 100 \\
\hline Research support engineer & 58 & 32 & 4 & 1 & 5 & 100 \\
\hline Research assistant/Project manager & 54 & 40 & 0 & 0 & 6 & 100 \\
\hline Engineer assistant & 55 & 33 & 5 & 1 & 7 & 100 \\
\hline Technician & 51 & 37 & 5 & 1 & 6 & 100 \\
\hline Technical assistant & 30 & 50 & 13 & 0 & 7 & 100 \\
\hline Other personnel & 61 & 29 & 3 & 1 & 6 & 100 \\
\hline All & 59 & 31 & 2 & 5 & 100
\end{tabular}

This type of catastrophe could cause a collapse of our societies: the basic needs (food, energy, health, etc.) will no longer be assured for the majority of the population 


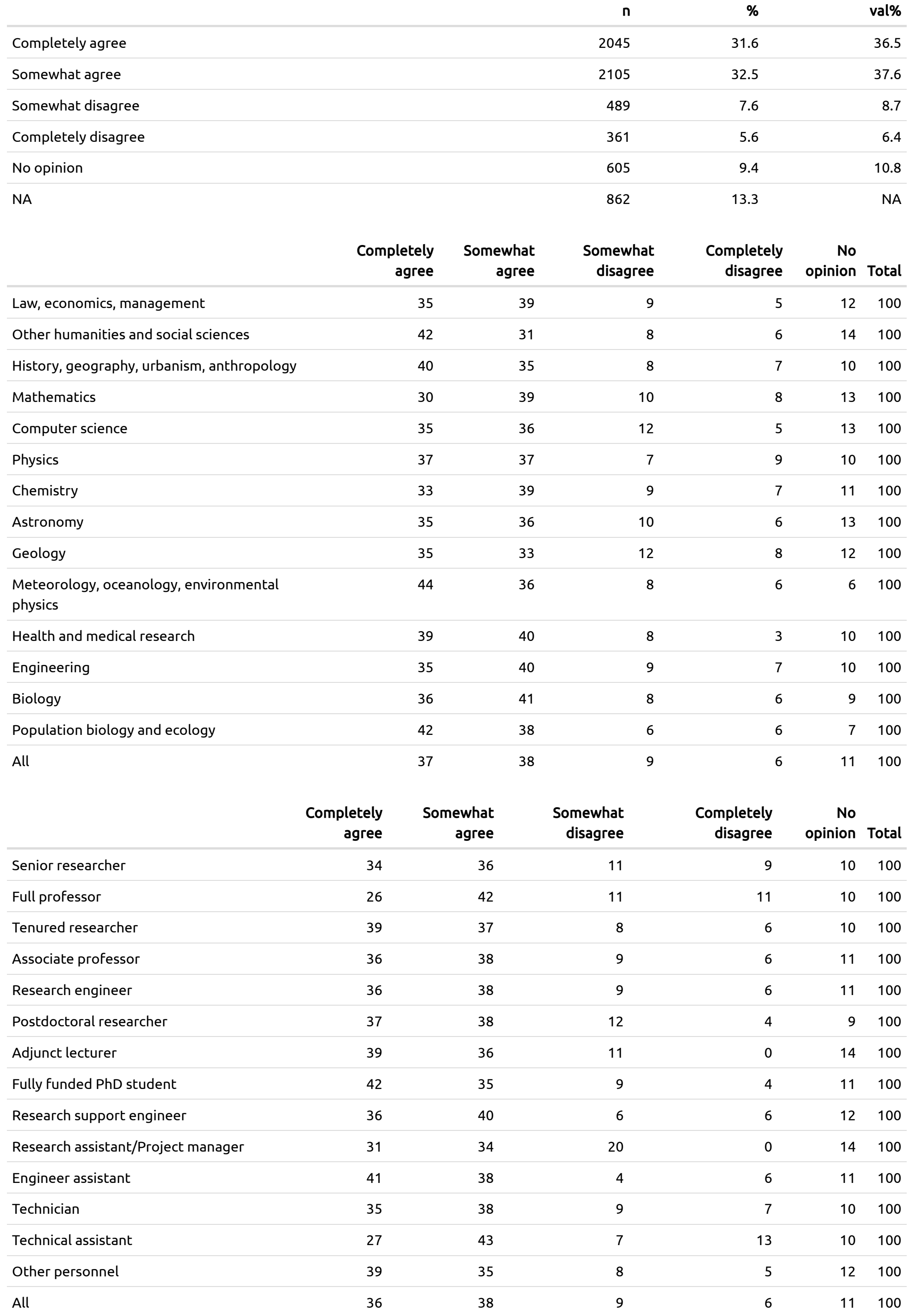


(Respondents disagreeing with previous question are classified as "Strongly disagree") 


\subsection{Profound changes in our professions}

Do you think that climate urgency calls for profound changes in the practice of our professior

Yes, strongly agree

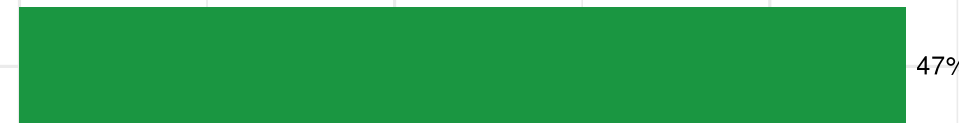

Yes, somewhat agree

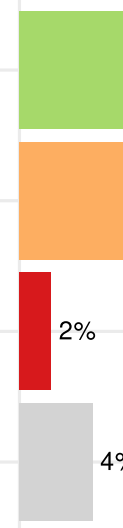

$0 \%$

$20 \%$

$60 \%$

Proportion of respondents

Interpretation: $47 \%$ of respondents think that climate urgency calls for profound changes in the practice of our professions Source: "Research personnel and climate change" survey, Labos 1point5, 2020

Coverage: personnel affiliated with a CNRS unit $(n=6341)$

Yes, strongly agree

Yes, somewhat agree

No, somewhat disagree

No, strongly disagree

No opinion

NA

\begin{tabular}{rr}
$\mathbf{n}$ & $\%$ \\
2996 & 46.3 \\
2594 & 40. \\
397 & 6. \\
107 & 1.7 \\
247 & 3.8 \\
126 & 1.9 \\
\hline
\end{tabular}

$\%$

46.3

40.1

6.1

1.7

3.8

1.9 val\%

\begin{tabular}{|c|c|c|c|c|c|c|}
\hline & $\begin{array}{r}\text { Yes, strongly } \\
\text { agree }\end{array}$ & $\begin{array}{r}\text { Yes, somewhat } \\
\text { agree }\end{array}$ & $\begin{array}{r}\text { No, somewhat } \\
\text { disagree }\end{array}$ & $\begin{array}{r}\text { No, strongly } \\
\text { disagree }\end{array}$ & $\begin{array}{r}\text { No } \\
\text { opinion }\end{array}$ & Total \\
\hline Law, economics, management & 52 & 37 & 4 & 3 & 3 & 100 \\
\hline Other humanities and social sciences & 50 & 36 & 8 & 1 & 5 & 100 \\
\hline $\begin{array}{l}\text { History, geography, urbanism, } \\
\text { anthropology }\end{array}$ & 48 & 40 & 7 & 1 & 4 & 100 \\
\hline Mathematics & 41 & 39 & 11 & 2 & 6 & 100 \\
\hline Computer science & 50 & 41 & 5 & 2 & 3 & 100 \\
\hline Physics & 45 & 38 & 10 & 3 & 4 & 100 \\
\hline Chemistry & 40 & 46 & 7 & 2 & 4 & 100 \\
\hline Astronomy & 50 & 39 & 6 & 2 & 2 & 100 \\
\hline Geology & 51 & 40 & 6 & 2 & 2 & 100 \\
\hline $\begin{array}{l}\text { Meteorology, oceanology, environmental } \\
\text { physics }\end{array}$ & 65 & 31 & 2 & 1 & 1 & 100 \\
\hline Health and medical research & 45 & 45 & 5 & 1 & 4 & 100 \\
\hline Engineering & 49 & 40 & 6 & 1 & 5 & 100 \\
\hline Biology & 41 & 49 & 6 & 2 & 3 & 100 \\
\hline Population biology and ecology & 58 & 35 & 3 & 1 & 3 & 100 \\
\hline All & 47 & 41 & 6 & 2 & 4 & 100 \\
\hline
\end{tabular}


Senior researcher

43

10

3

$4 \quad 100$

Full professor

40

Tenured researcher

44

40

13

3

$4 \quad 100$

Associate professor

46

44

6

2

$4 \quad 100$

Research engineer

47

Postdoctoral researcher

50

41

8

2

$4 \quad 100$

42

5

2

$4 \quad 100$

Adjunct lecturer

47

41

5

0

3100

Fully funded PhD student

55

40

3

3

6100

Research support engineer

51

36

4

3100

Research assistant/Project

55

42

3

1

3100

manager

Engineer assistant

48

42

3

$0 \quad 100$

Technician

46

Technical assistant

32

45

3

0

$4 \quad 100$

Other personnel

54

46

3

3100

All

47

2

1

0

$10 \quad 100$

6

2

$6 \quad 100$

2

$4 \quad 100$ 


\subsection{Reduction in emissions by one-third by 2030}

France has committed to reducing its greenhouse gas emissions by one-third by 2030 .

In this respect, do you think that public research should:

Set an example (reduce emissions by more than one-third)
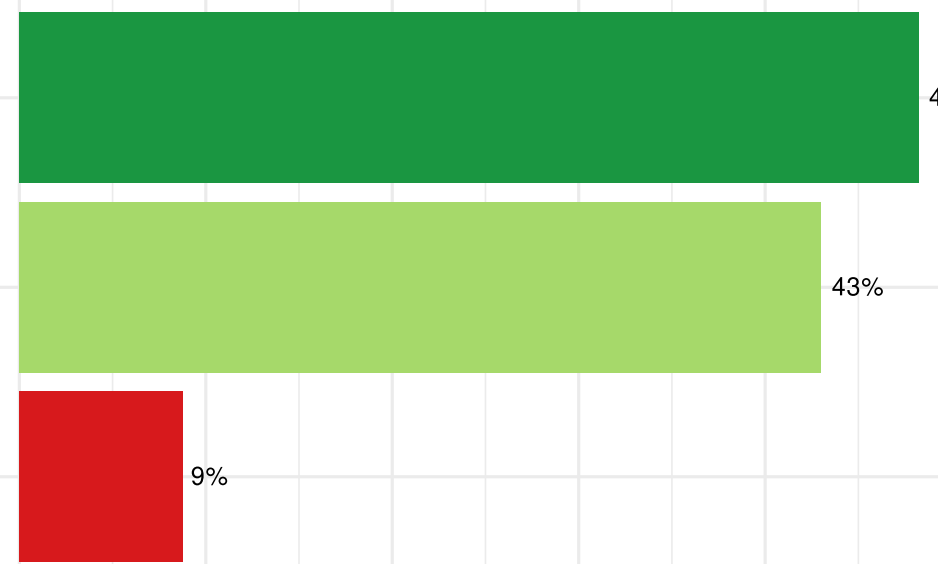

(reduce emissions by from an exemption

sions by less than one-third)

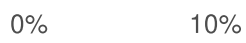

$20 \%$

$30 \%$

$40 \%$

Proportion of respondents

Interpretation: $48 \%$ of respondents think that public research should reduce its emissions by more than one-third by 2030 Source: "Research personnel and climate change" survey, Labos 1point5, 2020

Coverage: personnel affiliated with a CNRS unit $(n=5635)$

More than one-third

Around one-third

Less than one-third

NA

\begin{tabular}{rr}
$\mathbf{n}$ & $\%$ \\
2717 & 42. \\
2423 & 37. \\
495 & 7.7 \\
832 & 12. \\
\hline
\end{tabular}

$\%$

val\%

42.0

37.5

43.0

7.7

832

12.9

NA

\section{More than one-third}

Around one-third

Less than one-third Total

Law, economics, management

Other humanities and social sciences

History, geography, urbanism, anthropology

Mathematics

Computer science

Physics

Chemistry

Astronomy

Geology

Meteorology, oceanology, environmental physics

Health and medical research

Engineering

Biology

Population biology and ecology

All

58

53

50

51

53

39

42

50

41

52

42

52

43

54

48

35

$7 \quad 100$

43

$4 \quad 100$

44

$5 \quad 100$

43

$6 \quad 100$

39

$8 \quad 100$

44

$17 \quad 100$

46

$13 \quad 100$

40

$10 \quad 100$

40

13100

46

6100

42

$9 \quad 100$

$9 \quad 100$

$9 \quad 100$

$7 \quad 100$

39

$9 \quad 100$ 


48

$13 \quad 100$

Full professor

42

Tenured researcher

44

46

$12 \quad 100$

Associate professor

48

47

$9 \quad 100$

Research engineer

47

45

$7 \quad 100$

Postdoctoral researcher

49

44

9

100

Adjunct lecturer

56

42

$10 \quad 100$

Fully funded PhD student

52

36

$7 \quad 100$

Research support engineer

56

39

$9 \quad 100$

Research assistant/Project manager

51

Engineer assistant

53

54

33

54

37

$7 \quad 100$

Technician

Technical assistant

48

46

3100

40

6100

Other personnel

41

$5 \quad 100$

60

$7 \quad 100$

40

$7 \quad 100$

All

43

100 


\section{Practices}

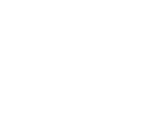

(n)

(2) . (n) (n)

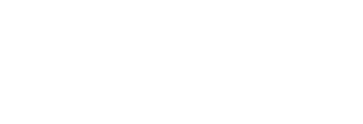




\subsection{Flights}

Analyses in this section cover only PhD-level positions (researchers, professors, research engineers and PhD students). 


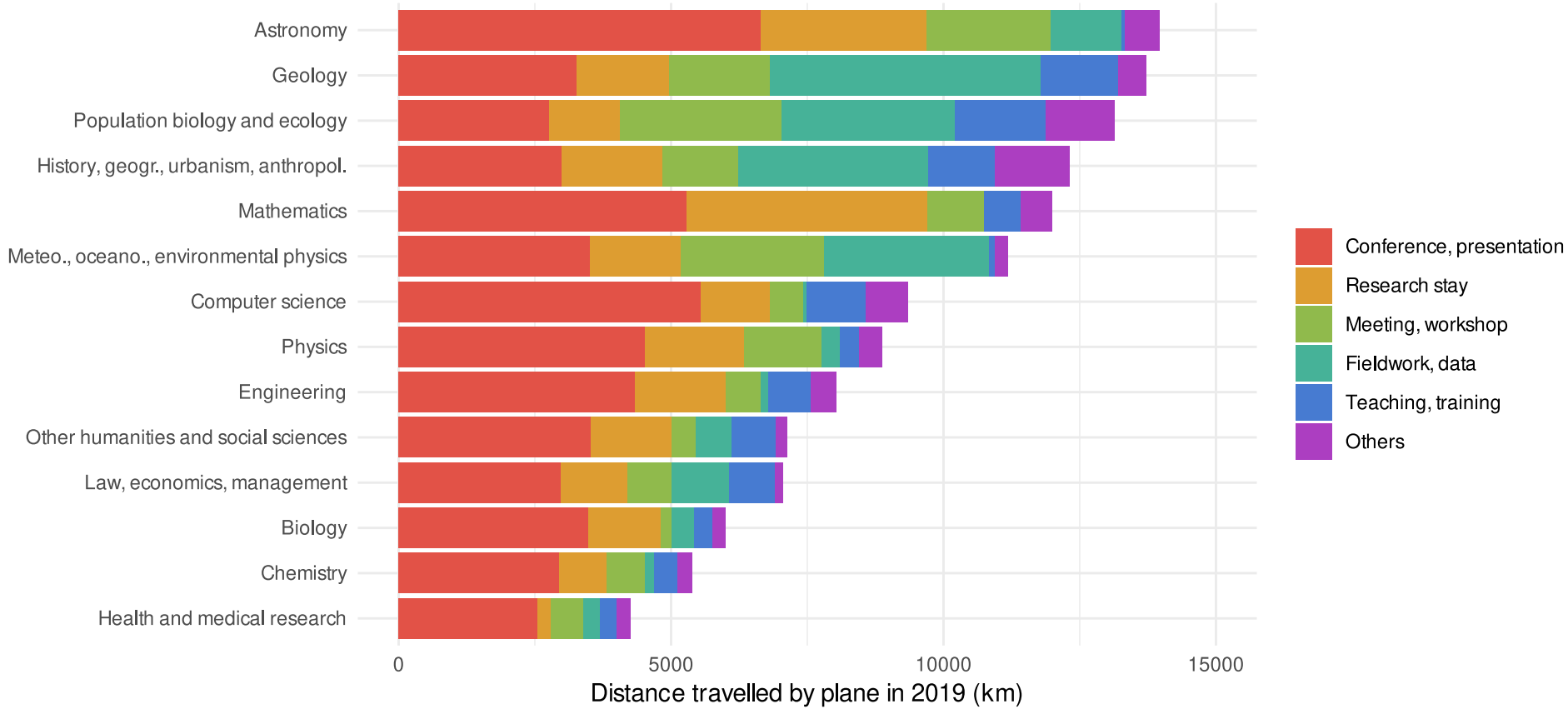

Distance travelled by plane in $2019(\mathrm{~km})$ :

\begin{tabular}{|c|c|c|c|c|c|c|c|}
\hline Discipline & $\begin{array}{r}\text { Fieldwork, } \\
\text { data }\end{array}$ & $\begin{array}{r}\text { Research } \\
\text { stay }\end{array}$ & $\begin{array}{r}\text { Meeting, } \\
\text { workshop }\end{array}$ & $\begin{array}{r}\text { Teaching, } \\
\text { training }\end{array}$ & Others & $\begin{array}{r}\text { Conference, } \\
\text { presentation }\end{array}$ & Total \\
\hline Law, economics, management & 1052 & 1225 & 807 & 844 & 150 & 2980 & 7133 \\
\hline $\begin{array}{l}\text { Other humanities and social } \\
\text { sciences }\end{array}$ & 660 & 1491 & 428 & 810 & 202 & 3529 & 7459 \\
\hline $\begin{array}{l}\text { History, geogr., urbanism, } \\
\text { anthropol. }\end{array}$ & 3491 & 1863 & 1383 & 1225 & 1376 & 2986 & 12685 \\
\hline Mathematics & 0 & 4416 & 1053 & 673 & 570 & 5280 & 12125 \\
\hline Computer science & 71 & 1274 & 606 & 1074 & 778 & 5545 & 9347 \\
\hline Physics & 346 & 1838 & 1409 & 356 & 414 & 4513 & 9050 \\
\hline Chemistry & 178 & 867 & 697 & 427 & 270 & 2947 & 5485 \\
\hline Astronomy & 1318 & 3043 & 2268 & 56 & 628 & 6642 & 13964 \\
\hline Geology & 4981 & 1697 & 1837 & 1427 & 505 & 3265 & 13872 \\
\hline $\begin{array}{l}\text { Meteo., oceano., environmental } \\
\text { physics }\end{array}$ & 3036 & 1676 & 2619 & 110 & 235 & 3511 & 11187 \\
\hline Health and medical research & 316 & 246 & 582 & 312 & 250 & 2545 & 4347 \\
\hline Engineering & 137 & 1676 & 628 & 792 & 471 & 4336 & 8324 \\
\hline Biology & 421 & 1341 & 184 & 328 & 242 & 3483 & 6020 \\
\hline Population biology and ecology & 3195 & 1293 & 2965 & 1667 & 1263 & 2762 & 13445 \\
\hline
\end{tabular}

Distance travelled by plane in 2019 (row \%): 
Fieldwork, Research data stay
Meeting, workshop
Teaching, training Others

\section{Discipline}

Law, economics, management

Other humanities and social

sciences

History, geogr., urbanism, anthropol.

Mathematics

Computer science

Physics

Chemistry

Astronomy

Geology

Meteo., oceano., environmental physics

Health and medical research

Engineering

Biology

Population biology and ecology

$15 \quad 17$

9

20

28

15

$0 \quad 36$

$1 \quad 14$

420

316

$9 \quad 22$

$36 \quad 12$

$27 \quad 15$

12

11

$12 \quad 2$

6

presentation Total

113

$42 \quad 100$

$47 \quad 100$

$10 \quad 11$

$24 \quad 100$

11

11

65

5

$44 \quad 100$

$14 \quad 6$

118

8

$59 \quad 100$

$20 \quad 16$

$16 \quad 4 \quad 5$

5

50100

$\begin{array}{lllll}13 & 8 & 5 & 54 & 100\end{array}$

$22 \quad 16$

$16 \quad 0 \quad 4$

$48 \quad 100$

13

$10 \quad 4$

4

$24 \quad 100$

23

12

$31 \quad 100$

7

$6 \quad 13$

$13 \quad 7 \quad 6$

6

$59 \quad 100$

20

8

$10 \quad 6$

$7 \quad 22$

3

24

10

22

54

$12 \quad 9$

$52 \quad 100$

$58 \quad 100$

$21 \quad 100$ 


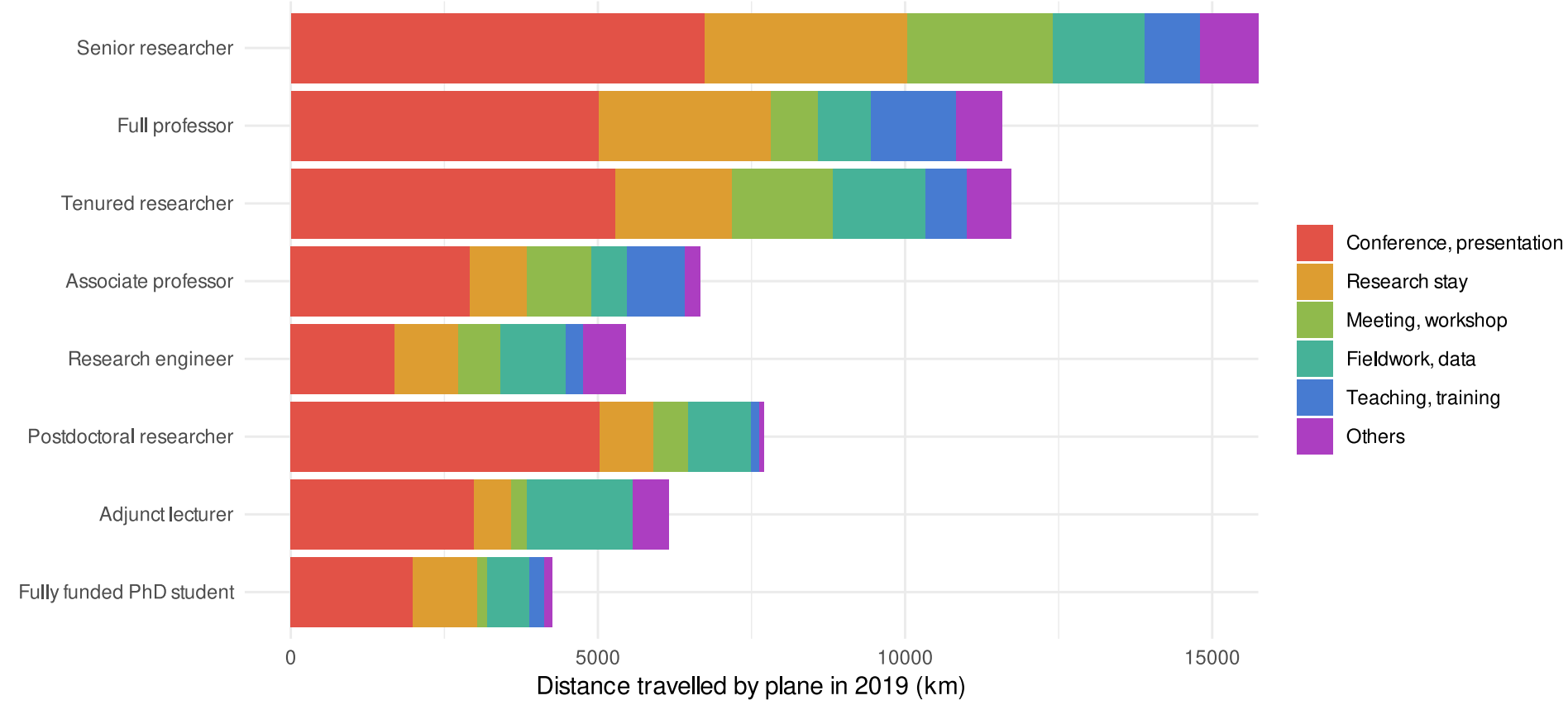

Distance travelled by plane in $2019(\mathrm{~km})$ :

$\begin{array}{lrrrrrr}\text { Status } & \begin{array}{r}\text { Fieldwork, } \\ \text { data }\end{array} & \begin{array}{r}\text { Research } \\ \text { stay }\end{array} & \begin{array}{r}\text { Meeting, } \\ \text { workshop }\end{array} & \begin{array}{r}\text { Teaching, } \\ \text { training }\end{array} \text { Others } & \begin{array}{r}\text { Conference, } \\ \text { presentation }\end{array} \\ \text { Total }\end{array}$

Distance travelled by plane in 2019 (row \%):

\begin{tabular}{|c|c|c|c|c|c|c|c|}
\hline Status & $\begin{array}{r}\text { Fieldwork, } \\
\text { data }\end{array}$ & $\begin{array}{r}\text { Research } \\
\text { stay }\end{array}$ & $\begin{array}{r}\text { Meeting, } \\
\text { workshop }\end{array}$ & $\begin{array}{r}\text { Teaching, } \\
\text { training }\end{array}$ & Others & $\begin{array}{l}\text { Conference, } \\
\text { presentation }\end{array}$ & Total \\
\hline Senior researcher & 9 & 21 & 15 & 6 & 6 & 42 & 100 \\
\hline Full professor & 7 & 24 & 6 & 12 & 6 & 42 & 100 \\
\hline Tenured researcher & 12 & 16 & 14 & 6 & 6 & 43 & 100 \\
\hline Associate professor & 9 & 14 & 16 & 14 & 4 & 43 & 100 \\
\hline Research engineer & 19 & 19 & 12 & 5 & 13 & 30 & 100 \\
\hline Postdoctoral researcher & 14 & 11 & 7 & 2 & 1 & 65 & 100 \\
\hline Adjunct lecturer & 28 & 10 & 4 & 0 & 9 & 48 & 100 \\
\hline $\begin{array}{l}\text { Fully funded PhD } \\
\text { student }\end{array}$ & 16 & 25 & 4 & 6 & 3 & 46 & 100 \\
\hline
\end{tabular}




\subsection{IT equipment}

\begin{tabular}{lrrr} 
& $\mathbf{n}$ & $\boldsymbol{\%}$ & val\% \\
\hline At least one device under 5 years old & 1838 & 28.4 & 62.2 \\
\hline No device under 5 years old & 1115 & 17.2 & 37.8 \\
\hline NA & 3514 & 54.3 & NA \\
& & $\%$ & val\% \\
\hline No device or a single device & $\mathbf{n}$ & \% & 57.6 \\
\hline Several devices & 1701 & 26.3 & 42.4 \\
NA & 1252 & 19.4 & NA
\end{tabular}

\section{All devices considered essential}

No device or a single device

Several devices

All
Some devices considered non-essential Total

17

41

27
$83 \quad 100$

$59 \quad 100$

$73 \quad 100$
At least one device under 5 years old

Law, economics, management

Other humanities and social sciences

History, geography, urbanism, anthropology

Mathematics

Computer science

Physics

Chemistry

Astronomy

Geology

Meteorology, oceanology, environmental physics

Health and medical research

Engineering

Biology

Population biology and ecology

All

No device under 5 years old Total

\begin{tabular}{lll}
55 & 45 & 100 \\
\hline 47 & 53 & 100 \\
\hline 49 & 51 & 100 \\
\hline 62 & 38 & 100 \\
73 & 27 & 100 \\
\hline 68 & 32 & 100 \\
\hline 67 & 33 & 100 \\
\hline 73 & 27 & 100 \\
\hline 69 & 31 & 100 \\
\hline 63 & 37 & 100 \\
\hline 61 & 39 & 100 \\
\hline 68 & 32 & 100 \\
\hline 62 & 38 & 100 \\
\hline 66 & 34 & 100 \\
\hline 62 & 38 & 100 \\
\hline
\end{tabular}


Other humanities and social sciences 63

History, geography, urbanism, anthropology

Mathematics

57

Computer science

52

$43 \quad 100$

Physics

Chemistry

60

Astronomy

56

Geology

43

Meteorology, oceanology, environmental physics

48

Health and medical research

56

Engineering

55

Biology

54

$40 \quad 100$

Population biology and ecology 56

57

$44 \quad 100$

$57 \quad 100$

$52 \quad 100$

$44 \quad 100$

$45 \quad 100$

$46 \quad 100$

All

$44 \quad 100$

$43 \quad 100$

All devices considered essential Some devices considered non-essential Total

Law, economics, management

Other humanities and social sciences

History, geography, urbanism, anthropology

Mathematics

Computer science

Physics

Chemistry

Astronomy

Geology

Meteorology, oceanology, environmental physics

Health and medical research

Engineering

Biology

Population biology and ecology

All
23

28

25

25

28

28

24

23

31

30

28

30

24

34

27
$77 \quad 100$

72100

75100

$\begin{array}{ll}75 & 100\end{array}$

$72 \quad 100$

$72 \quad 100$

$76 \quad 100$

$77 \quad 100$

$69 \quad 100$

$70 \quad 100$

$72 \quad 100$

$70 \quad 100$

$76 \quad 100$

$66 \quad 100$

$73 \quad 100$ 
Full professor 65

Tenured researcher 67

Associate professor 67

33100

Research engineer 68

Postdoctoral researcher 32100

Adjunct lecturer 43 $57 \quad 100$

Fully funded PhD student 29

Research support engineer 56 $44 \quad 100$

Research assistant/Project manager 67

33100

Engineer assistant 53 $47 \quad 100$

Technician 64

$36 \quad 100$

Technical assistant 54 $46 \quad 100$

Other personnel 43 $57 \quad 100$ All

\begin{tabular}{lrrr} 
& No device or a single device & Several devices & Total \\
\hline Senior researcher & 40 & 60 & 100 \\
\hline Full professor & 41 & 59 & 100 \\
\hline Tenured researcher & 54 & 46 & 100 \\
\hline Associate professor & 53 & 47 & 100 \\
\hline Research engineer & 51 & 49 & 100 \\
\hline Postdoctoral researcher & 84 & 16 & 100 \\
\hline Adjunct lecturer & 79 & 21 & 100 \\
\hline Fully funded PhD student & 77 & 23 & 100 \\
\hline Research support engineer & 58 & 42 & 100 \\
\hline Research assistant/Project manager & 79 & 21 & 100 \\
\hline Engineer assistant & 53 & 47 & 100 \\
\hline Technician & 64 & 36 & 100 \\
\hline Technical assistant & 57 & 43 & 100 \\
\hline Other personnel & 81 & 19 & 100 \\
\hline All & 58 & 42 & 100
\end{tabular}




\subsection{Leftover budget money}

\begin{tabular}{lrrr} 
& $\mathbf{n}$ & $\%$ & val\% \\
\hline Has had leftover budget money to spend & 3642 & 56.3 & 60.1 \\
\hline Has not had leftover budget money to spend & 2419 & 37.4 & 39.9 \\
\hline NA & 406 & 6.3 & NA
\end{tabular}

Having used leftover budget money to buy IT equipment considered as non-essential:

\begin{tabular}{lrrr} 
& $\mathbf{n}$ & $\%$ & val\% \\
\hline Yes & 1241 & 19.2 & 20.5 \\
\hline No & 2302 & 35.6 & 38.0 \\
\hline I have not had leftover budget money to spend & 2517 & 38.9 & 41.5 \\
NA & 407 & 6.3 & NA
\end{tabular}

\begin{tabular}{lrrr} 
& $\mathbf{n}$ & $\boldsymbol{\%}$ & val\% \\
\hline Yes & 1241 & 19.2 & 35 \\
\hline No & 2302 & 35.6 & 65 \\
\hline NA & 2924 & 45.2 & NA
\end{tabular}

\begin{tabular}{lllll} 
& Yes & No & I have not had leftover budget money to spend & Total \\
\hline Law, economics, management & 15 & 30 & 54 & 100 \\
\hline Other humanities and social sciences & 24 & 32 & 45 & 100 \\
\hline History, geography, urbanism, anthropology & 19 & 39 & 42 & 100 \\
\hline Mathematics & 24 & 35 & 41 & 100 \\
\hline Computer science & 30 & 30 & 40 & 100 \\
\hline Physics & 22 & 45 & 33 & 100 \\
\hline Chemistry & 14 & 42 & 39 & 100 \\
\hline Astronomy & 20 & 39 & 43 & 100 \\
\hline Geology & 18 & 45 & 41 & 37 \\
\hline Meteorology, oceanology, environmental physics & 24 & 37 & 100 \\
\hline Health and medical research & 14 & 40 & 39 & 100 \\
\hline Engineering & 23 & 39 & 46 & 100 \\
\hline Biology & 19 & 42 & 38 & 100 \\
\hline Population biology and ecology & 27 & 35 & 39 & 100 \\
\hline All & 20 & 38 & 38 & 100 \\
\hline & & 41 & 100
\end{tabular}




\begin{tabular}{|c|c|c|c|c|}
\hline & Yes & No & I have not had leftover budget money to spend & Total \\
\hline Senior researcher & 25 & 54 & 21 & 100 \\
\hline Full professor & 32 & 46 & 22 & 100 \\
\hline Tenured researcher & 22 & 51 & 28 & 100 \\
\hline Associate professor & 28 & 42 & 31 & 100 \\
\hline Research engineer & 22 & 43 & 35 & 100 \\
\hline Postdoctoral researcher & 9 & 21 & 70 & 100 \\
\hline Adjunct lecturer & 14 & 17 & 69 & 100 \\
\hline Fully funded PhD student & 6 & 19 & 76 & 100 \\
\hline Research support engineer & 21 & 34 & 45 & 100 \\
\hline Research assistant/Project manager & 0 & 30 & 70 & 100 \\
\hline Engineer assistant & 19 & 33 & 48 & 100 \\
\hline Technician & 24 & 32 & 44 & 100 \\
\hline Technical assistant & 18 & 32 & 50 & 100 \\
\hline Other personnel & 11 & 29 & 60 & 100 \\
\hline All & 20 & 38 & 42 & 100 \\
\hline
\end{tabular}

Having used leftover budget money to buy plane tickets considered as non-essential:

\begin{tabular}{|c|c|c|c|}
\hline & $\mathbf{n}$ & $\%$ & val\% \\
\hline Yes & 192 & 3.0 & 3.2 \\
\hline No & 3275 & 50.6 & 54.4 \\
\hline I have not had leftover budget money to spend & 2554 & 39.5 & 42.4 \\
\hline NA & 446 & 6.9 & NA \\
\hline
\end{tabular}

\begin{tabular}{lrrrr} 
& $\mathbf{n}$ & \% & \\
\hline Yes & 192 & 3.0 & 5.5 \\
No & 3275 & 50.6 & \\
NA & 3000 & 46.4 & NA
\end{tabular}


Law, economics, management

Other humanities and social sciences

History, geography, urbanism, anthropology

Mathematics

$7 \quad 49$

$43 \quad 100$

Computer science

$5 \quad 53$

Physics

265

$42 \quad 100$

Chemistry

255

$34 \quad 100$

Astronomy

652

$43 \quad 100$

Geology

362

$42 \quad 100$

Meteorology, oceanology, environmental physics

652

$35 \quad 100$

Health and medical research

251

$42 \quad 100$

Engineering

258

$47 \quad 100$

Biology

160

$40 \quad 100$

Population biology and ecology

260

$39 \quad 100$

All

Yes No

I have not had leftover budget money to spend

Total

\begin{tabular}{lcc}
\hline Senior researcher & 4 & 75 \\
\hline Full professor & 4 & 73 \\
\hline Tenured researcher & 3 & 69 \\
\hline Associate professor & 4 & 64 \\
\hline Research engineer & 3 & 62 \\
\hline Postdoctoral researcher & 3 & 27 \\
\hline Adjunct lecturer & 3 & 22 \\
\hline Fully funded PhD student & 3 & 21 \\
\hline Research support engineer & 1 & 53 \\
\hline Research assistant/Project manager & 3 & 27 \\
\hline Engineer assistant & 3 & 47 \\
\hline Technician & 4 & 48 \\
\hline Technical assistant & 6 & 50 \\
\hline Other personnel & 2 & 36 \\
\hline All & 3 & 54
\end{tabular}

$21 \quad 100$

$23 \quad 100$

$27 \quad 100$

$31 \quad 100$

$36 \quad 100$

$69 \quad 100$

$74 \quad 100$

$76 \quad 100$

$46 \quad 100$

$70 \quad 100$

$50 \quad 100$

$47 \quad 100$

$44 \quad 100$

$62 \quad 100$

$42 \quad 100$ 


\subsection{Reductions in personal GHG emissions in a professional setting by 2030}

Are you willing to reduce your greenhouse gas emissions by 2030 in the following areas?

\begin{tabular}{l|rrrr} 
& $\begin{array}{r}\text { Yes, by at } \\
\text { least one-third }\end{array}$ & $\begin{array}{r}\text { Yes, but by less } \\
\text { than one-third }\end{array}$ & $\begin{array}{r}\text { No, as they are } \\
\text { already very low } \begin{array}{r}\text { No } \\
\text { opinion }\end{array}\end{array}$ & $\begin{array}{r}\text { Not } \\
\text { No }\end{array}$ concerned \\
Total
\end{tabular}

Proportion of "No" anwsers, excluding those not concerned:

Scientific

experiments

and

observations
Travel for fieldwork observation or data collection

(by plane, car or boat)
Commuting to work by car, motorbike, scooter or plane
IT equipment

and its

replacement

rates
Flights for conferences, meetings, and congresses

Law, economics,

19

15

9

7

2

management

Other humanities

18

13

22

3

and social sciences

14

16

10

5

urbanism,

anthropology

Mathematics

Computer science

6

Physics

Chemistry

Astronomy

Geology

Meteorology,

32

oceanology,

environmental

physics

Health and medical

20

15

9

research

Engineering

19

Biology

Population biology

26

and ecology

23

All

5

12

21

14

5

12

2

17

12

14

26

22

2

1

1

$\begin{array}{lll}16 & 5 & 2 \\ 15 & 9 & 1 \\ 17 & 9 & 3 \\ 17 & 9 & 3 \\ 15 & 8 & 4 \\ 8 & 9 & 2 \\ 0 & 6 & 1\end{array}$

2

3

1 
Scientific

experiments Travel for fieldwork, observation and or data collection (by plane, car observations

or boat)
Commuting to work by car, motorbike, scooter or plane
IT equipment and its

replacement

rates
Flights for conferences, meetings, and congresses

\section{Senior}

29

16

17

9

researcher

Full professor

Tenured

researcher

Associate

professor

Research

engineer

Postdoctoral

researcher

Adjunct lecturer

Fully funded

PhD student

Research

support

engineer

Research

assistant/Project

manager

Engineer

17

assistant

Technician

13

Technical

0

assistant

Other personnel

17

All

27

19

22

40

0

20

17

7

3

$23 \quad 15$

18

11

7

12

8

13

13

6

2

15

17

8

2

0

0

22

0

0

50

0

0

14

0

4

4

11

13

5

0

0

11

0

0

9

14

5

2

8

21

10

3

4

9

17

14

5

7

3

14 
Are you willing to reduce your greenhouse gas emissions by 2030 in the following areas?
$100 \%$
$75 \%$
$50 \%$
$25 \%$
$0 \%$

Flights for conferences, meetings, and congresses

IT equipment and its replacement rates

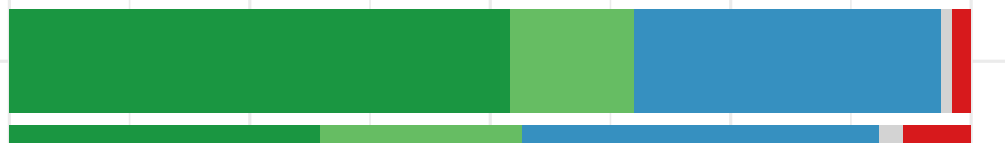

Commuting to work by car, motorbike,

Commuting to work by car, motorbike, scooter or plane

Travel for fieldwork, observation or data collection (by plane, car or boat)

Scientific experiments and observations
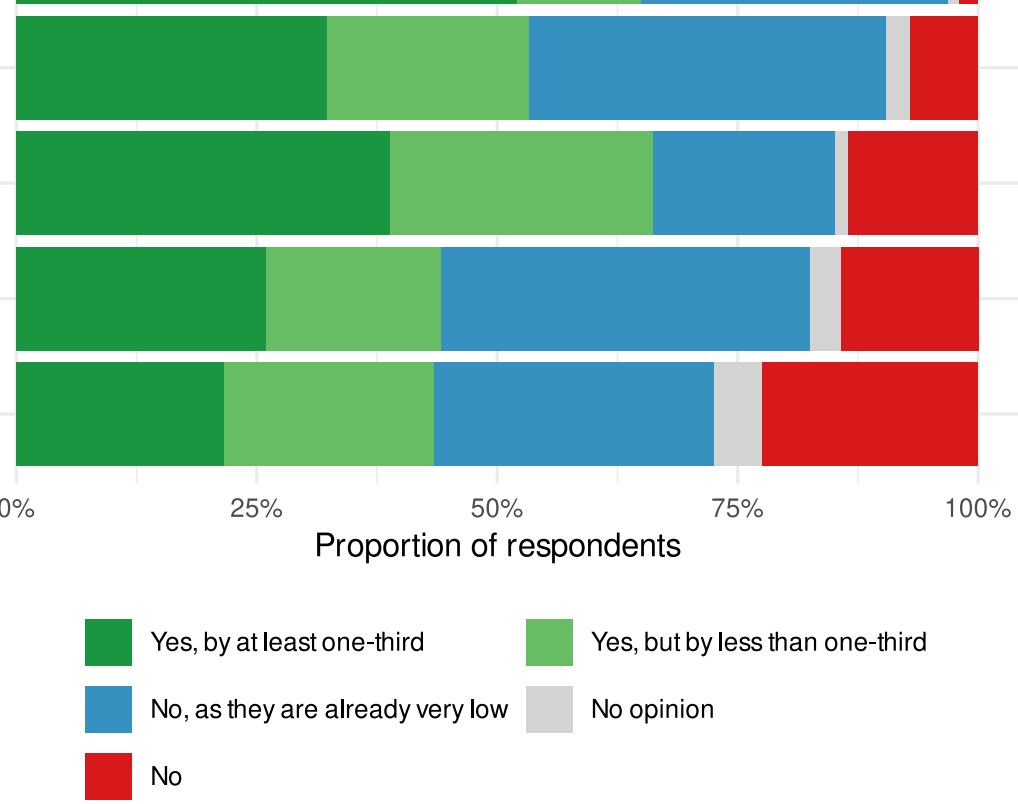

Yes, by at least one-third

Yes, but by less than one-third

No, as they are already very low

No opinion

No

Note: the proportion of people concerned varies according to the question Interpretation: $32 \%$ of respondents say they are unable to reduce the emissions they generate by flying to conferences as they are already very low Source: "Research personnel and climate change" survey, Labos 1point5, 2020 Coverage: personnel affiliated with a CNRS unit $(n=4107)$ 


\subsection{Risks associated with reduced flying}

What would be the risks of implementing a policy on the reduction of professional air travel in research?

\begin{tabular}{|c|c|c|c|c|c|c|}
\hline & $\begin{array}{r}\text { It is } \\
\text { unlikely }\end{array}$ & $\begin{array}{l}\text { It is likely but it is } \\
\text { not a problem }\end{array}$ & $\begin{array}{r}\text { No } \\
\text { opinion }\end{array}$ & $\begin{array}{l}\text { It is likely and it is } \\
\text { a problem }\end{array}$ & $\begin{array}{r}\text { Not } \\
\text { concerned }\end{array}$ & Total \\
\hline Hinder the integration of young researchers & 30 & 5 & 9 & 51 & 5 & 100 \\
\hline $\begin{array}{l}\text { Hinder your access to some field sites or the } \\
\text { collection/production of certain data }\end{array}$ & 19 & 7 & 4 & 26 & 45 & 100 \\
\hline Increase bureaucracy & 26 & 13 & 16 & 42 & 5 & 100 \\
\hline Isolate French research from the rest of the world & 43 & 6 & 6 & 41 & 4 & 100 \\
\hline Reduce the dissemination of your work & 37 & 19 & 4 & 34 & 6 & 100 \\
\hline Reduce the quality of your work & 65 & 7 & 4 & 17 & 7 & 100 \\
\hline Reduce your access to funding & 57 & 9 & 10 & 14 & 10 & 100 \\
\hline $\begin{array}{l}\text { Reduce some of the advantages offered to you by } \\
\text { your profession }\end{array}$ & 19 & 54 & 5 & 10 & 12 & 100 \\
\hline
\end{tabular}

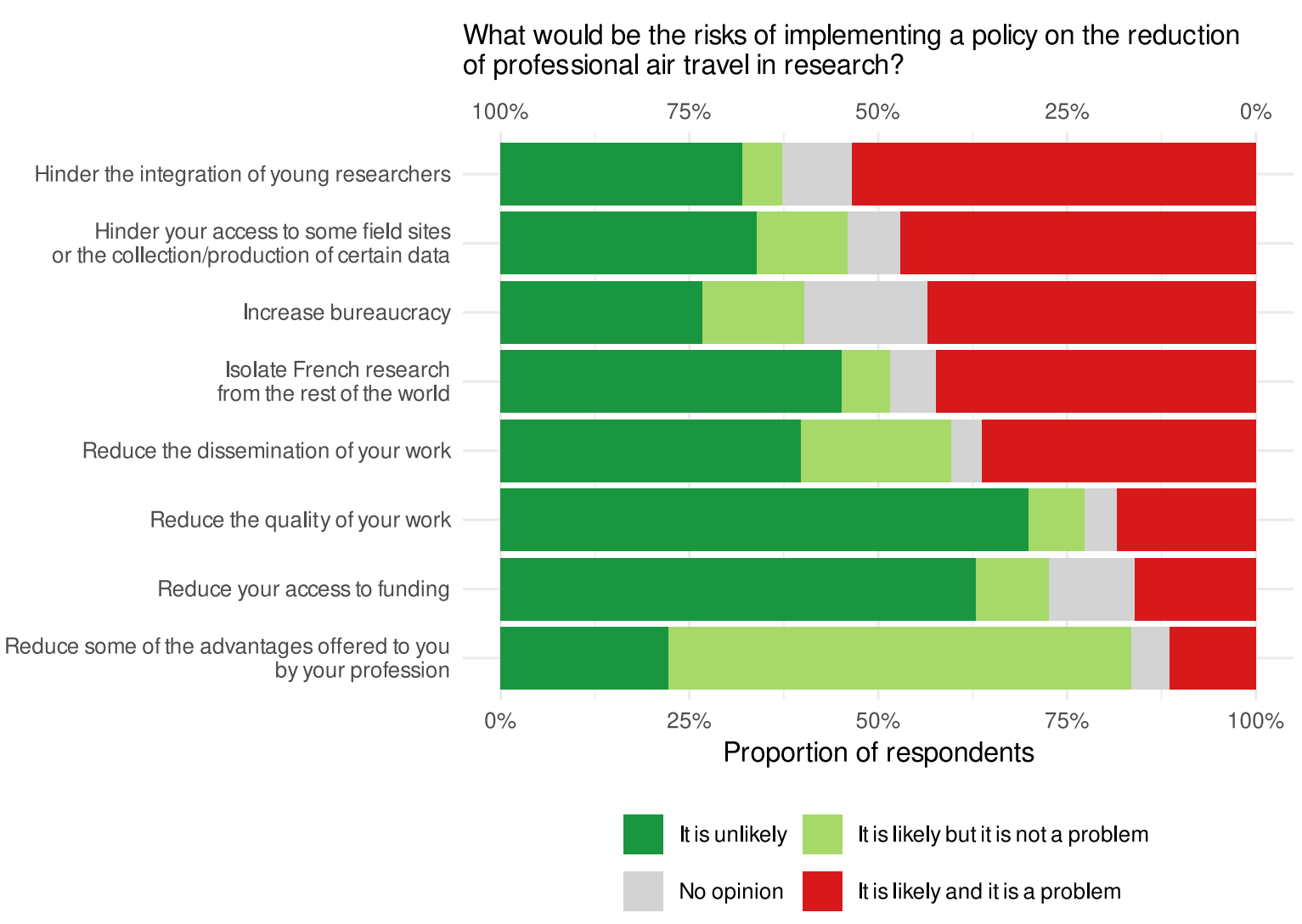

Note: the proportion of people concerned varies according to the question Interpretation: $54 \%$ of respondents think it likely that a reduction in the number of flights would negatively impact the integration of young researchers and that it is a problem Source: "Research personnel and climate change" survey, Labos 1point5, 2020 Coverage: personnel affiliated with a CNRS unit $(n=4760)$

Proportion of "It is likely and it is a problem" answers, excluding those not concerned: 
Law, economics, management

Other humanities and social sciences

History, geography, urbanism,

anthropology

Mathematics

Computer science

Physics

Chemistry

Astronomy

Geology

Meteorology, oceanology,

environmental physics

Health and medical research

Engineering

Biology

Population biology and ecology

Isolate French research from the rest of the world

\begin{tabular}{lr} 
Senior researcher & 49 \\
\hline Full professor & 43 \\
\hline Tenured researcher & 42 \\
\hline Associate professor & 41 \\
\hline Research engineer & 35 \\
\hline Postdoctoral researcher & 36 \\
\hline Adjunct lecturer & 38 \\
\hline Fully funded PhD student & 37 \\
\hline Research support & 38 \\
engineer & 36 \\
\hline Research assistant/Project & 39 \\
\hline manager & 39 \\
\hline Engineer assistant & 32 \\
\hline Technician & 39 \\
\hline Technical assistant & 39 \\
\hline Other personnel & \\
\hline All & 39 \\
\hline
\end{tabular}

Hinder the integration of young researchers
Reduce the dissemination of your work

$\begin{array}{lll}49 & 60 & 41 \\ 53 & 62 & 36 \\ 43 & 56 & 39 \\ 42 & 57 & 36 \\ 41 & 46 & 30 \\ 35 & 56 & 40 \\ 36 & 46 & 40 \\ 38 & 49 & 39 \\ 37 & 34 & 24 \\ 38 & & 31 \\ 36 & 42 & 25 \\ 39 & & 19 \\ 20 & 38 & 40 \\ 39 & 40 & 33 \\ 42 & 25 & 36\end{array}$




\subsection{Reductions in personal GHG emissions of experimental equipment by 2030}

Are you willing to reduce by 2030 the greenhouse gas emissions generated by the production and operation of equipment for your scientific experiments and observations by the following means?

\begin{tabular}{|c|c|c|c|c|c|c|c|}
\hline & $\begin{array}{r}\text { Yes, by at least } \\
\text { one-third }\end{array}$ & $\begin{array}{l}\text { Yes, but by less } \\
\text { than one-third }\end{array}$ & $\begin{array}{l}\text { No, as they are } \\
\text { already very low }\end{array}$ & No & $\begin{array}{r}\text { No } \\
\text { opinion }\end{array}$ & $\begin{array}{r}\text { Not } \\
\text { concerned }\end{array}$ & Total \\
\hline $\begin{array}{l}\text { Replacing the equipment at a slower } \\
\text { rate }\end{array}$ & 25 & 19 & 31 & 12 & 3 & 9 & 100 \\
\hline $\begin{array}{l}\text { Using or developing simpler systems } \\
\text { (low-tech) }\end{array}$ & 22 & 22 & 10 & 19 & 8 & 19 & 100 \\
\hline $\begin{array}{l}\text { Using equipment less frequently or } \\
\text { less intensively }\end{array}$ & 12 & 19 & 20 & 32 & 4 & 13 & 100 \\
\hline $\begin{array}{l}\text { Using less equipment in } \\
\text { experimental setups }\end{array}$ & 9 & 16 & 17 & 34 & 5 & 18 & 100 \\
\hline
\end{tabular}

Are you willing to reduce by 2030 the greenhouse gas emissions generated by the production and operation of equipment for your scientific experiments and observations by the following means?

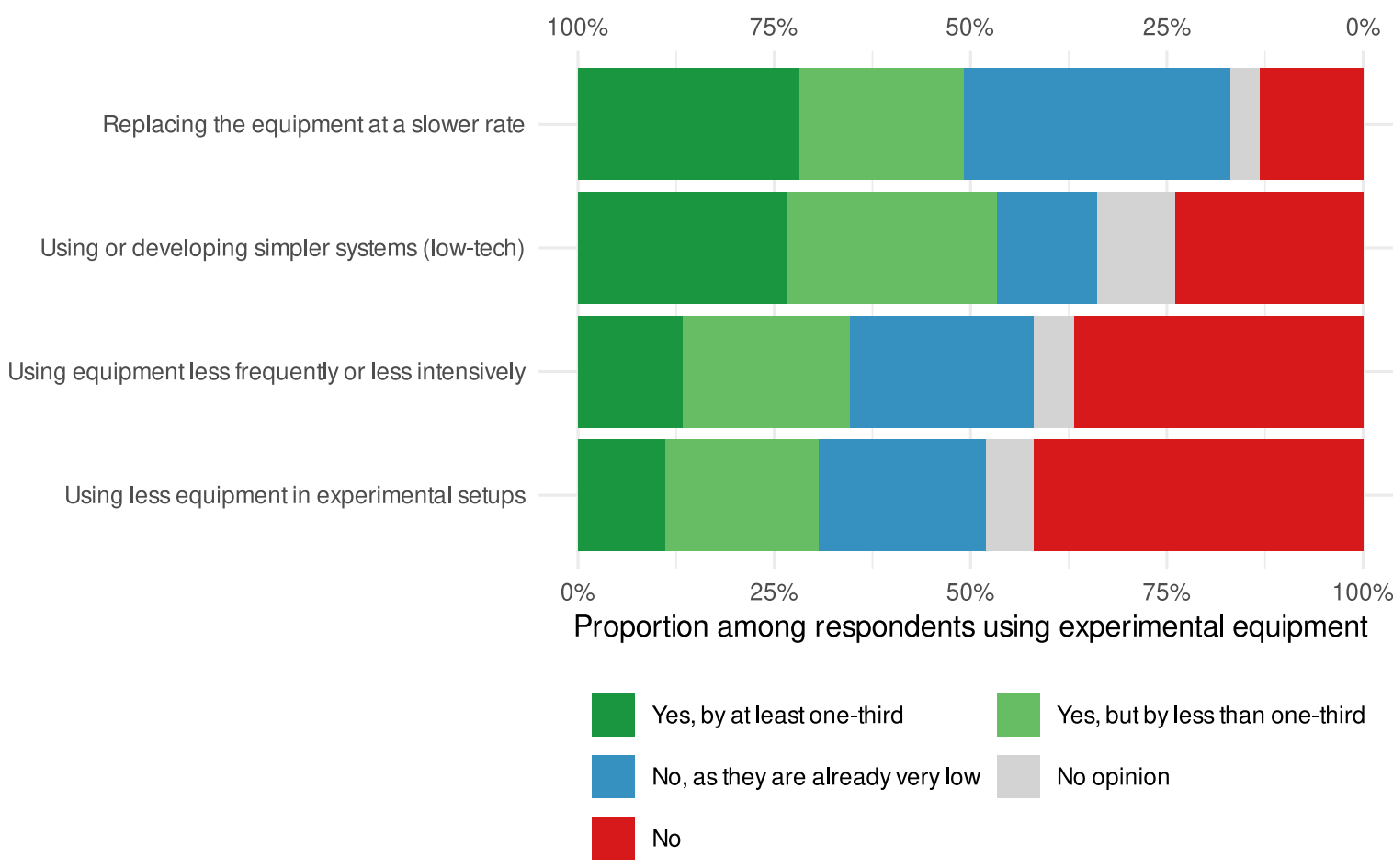

Note: the proportion of people concerned varies according to the question. Interpretation: $34 \%$ of respondents say they are unable to reduce their emissions by replacing equipment at a slower rate because they are already very low.

Source: "Research personnel and climate change" survey, Labos 1point5, 2020 Coverage: personnel associated with a CNRS unit and using experimental equipment $(n=2257)$ 


\subsection{Risks associated with reduced emissions of experimental equipment}

What would be the risks of a policy on reducing the greenhouse gas emissions generated by the production and operation of equipment for scientific experiments and observations?

\begin{tabular}{|c|c|c|c|c|c|c|}
\hline & $\begin{array}{r}\text { It is } \\
\text { unlikely }\end{array}$ & $\begin{array}{r}\text { It is likely but it is not a } \\
\text { problem }\end{array}$ & $\begin{array}{r}\text { No } \\
\text { opinion }\end{array}$ & $\begin{array}{r}\text { It is likely and it is a } \\
\text { problem }\end{array}$ & $\begin{array}{r}\text { Not } \\
\text { concerned }\end{array}$ & Total \\
\hline $\begin{array}{l}\text { Require you to change research } \\
\text { themes }\end{array}$ & 51 & 17 & 6 & 16 & 10 & 100 \\
\hline $\begin{array}{l}\text { Reduce your number of } \\
\text { publications }\end{array}$ & 32 & 20 & 11 & 25 & 11 & 100 \\
\hline Reduce your access to funding & 38 & 7 & 14 & 29 & 11 & 100 \\
\hline $\begin{array}{l}\text { Set you back compared with rival } \\
\text { teams }\end{array}$ & 24 & 16 & 11 & 40 & 9 & 100 \\
\hline Reduce the quality of your work & 32 & 10 & 7 & 45 & 6 & 100 \\
\hline
\end{tabular}

What would be the risks of a policy on reducing the greenhouse gas emissions generated by the production and operation of equipment for scientific experiments and observations?

$\begin{array}{llll}100 \% & 75 \% & 50 \% & 25 \%\end{array}$

Reduce the quality of your work

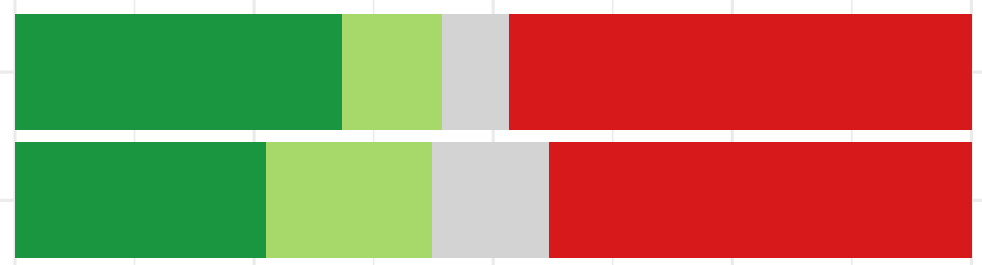

Reduce your access to funding

Reduce your number of publications

Require you to change research themes
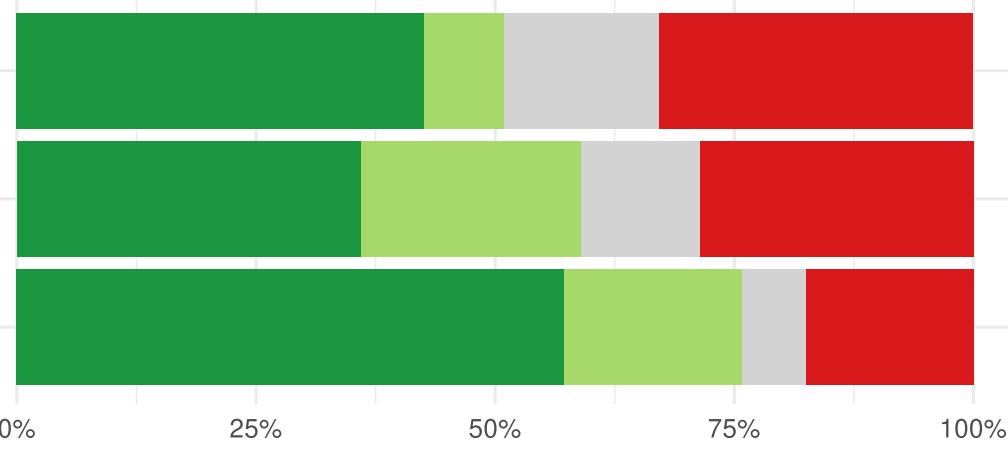

Proportion among respondents using experimental equipment

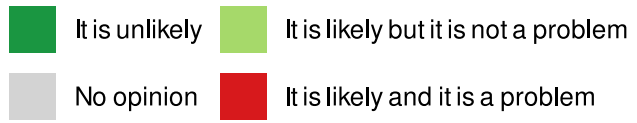

Note: the proportion of people concerned varies according to the question ents think it likely that a reduction in the number of flights would negatively impact the integration of young researchers and that it is a problem. Source: "Research personnel and climate change" survey, Labos 1point5, 2020 Coverage: personnel associated with a CNRS unit and using experimental equipment $(n=3173)$ 


\subsection{Institutional solutions}

What actions should research institutions and laboratories take to reduce their greenhouse gas emissions?

$\begin{array}{rrrrr}\text { It is a } & \text { It is } & \text { No } & \text { It should not be } \\ \text { priority } & \text { secondary } & \text { opinion } & \text { implemented } & \text { Total }\end{array}$

When replacing equipment, prefer those consuming less energy even if more expensive

When organising events, prefer service providers offering local or vegetarian food

75

18

4100

Finance train tickets even if more expensive or requires a longer stay

Do not renew functional computer equipment before a minimum of 5 years of age

Prohibit air travel when the same journey takes less than 6 hours by train

Regularly draft and disseminate detailed carbon assessments

Reduce the importance of conferences and presentations abroad in career assessments

Finance carbon offsetting initiatives

29

3

implemented Total

Impose a cap on the number of flights per person

Add carbon emissions to the main selection criteria for project funding

$\begin{array}{lllll}72 & 17 & 5 & 6 & 100 \\ 69 & 20 & 3 & 8 & 100 \\ 73 & 15 & 3 & 9 & 100 \\ 51 & 36 & 7 & & \\ 61 & 22 & 8 & 6 & 100 \\ 39 & 33 & 16 & 9 & 100 \\ 54 & 18 & 7 & & \\ 35 & 30 & 8 & 22 & 100 \\ & & & 27 & 100\end{array}$

What actions should research institutions and laboratories take to reduce their greenhouse gas emissions?

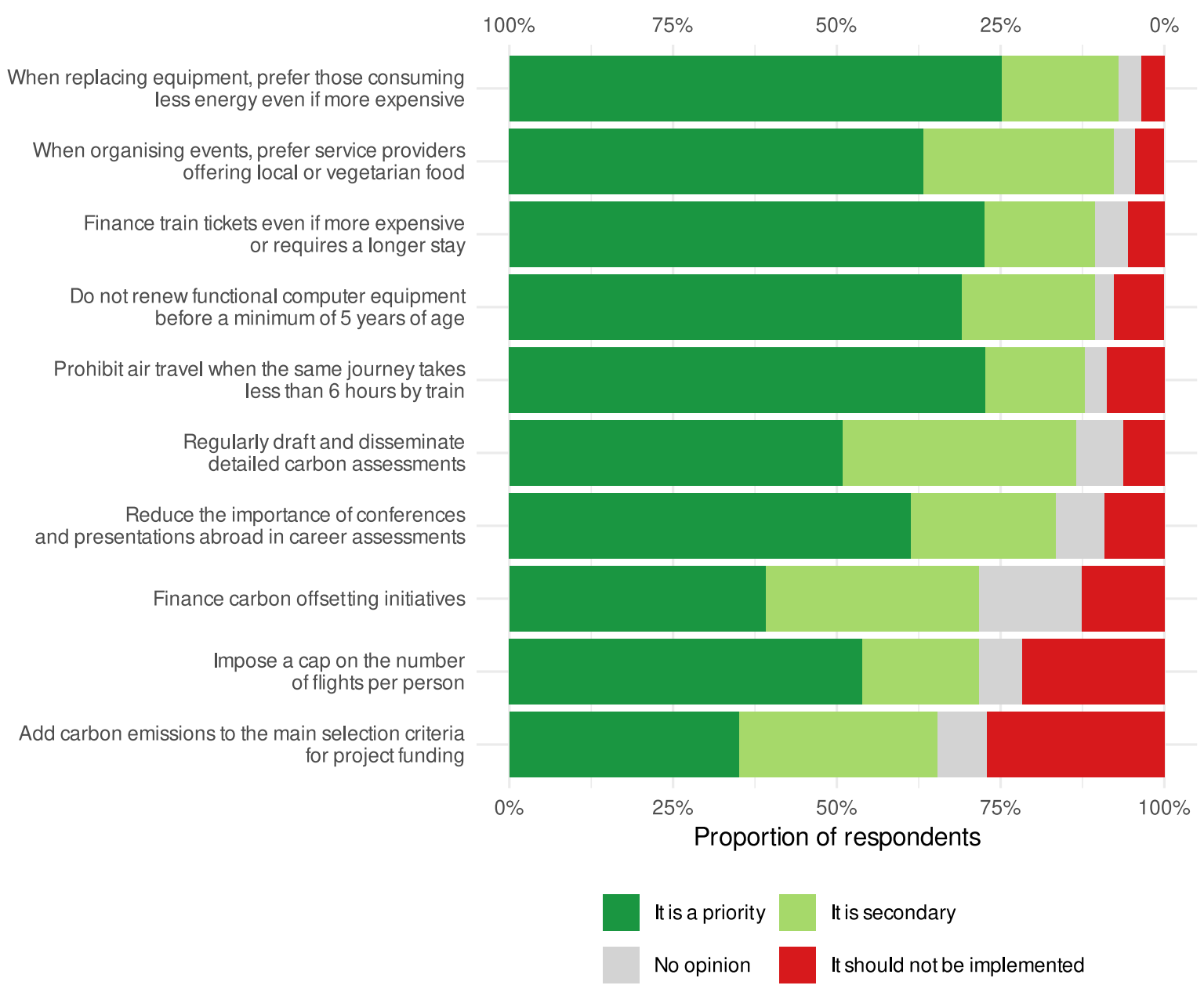

Interpretation: $75 \%$ of respondents think that choosing more energy-efficient equipment is a priority Source: "Research personnel and climate change" survey, Labos 1 point5, 2020 Coverage: personnel affiliated with a CNRS unit $(n=5698)$ 


\section{S2 Appendix. Calculation of air travel distances and the corresponding GHG emissions}

The questionnaire includes questions on air travel for professional reasons in 2019 through two distinct sets of questions. The first set, concerning the number of flights and total flight time (to pick among four possible ranges), was asked to all respondents. This information was not used here; instead, we used information generated by a second set of more detailed questions posed to half of the respondents in a random manner.

The latter set of questions consists of a table in which respondents were asked to enter all the airplane journeys taken in 2019 (up to a maximum of 5 journeys), specifying for each one the number of times the journey was taken, the city of departure and arrival, the number of days spent at the destination, the main reason and any secondary reason for the trip. This approach encouraged respondents to recount in detail their professional trips in 2019 rather than give an approximate total number. A list of the main French and international airports was provided to the respondents, helping them to select the cities (without forcing them to choose from the list) and serving to limit manual recoding and ambiguous names. The GPS coordinates of the corresponding airports were obtained from a list of world airports and the orthodromic distance between the place of departure and arrival was calculated using the haversine formula. The distances reported are thus theoretical, the real journeys necessarily being longer, notably for flights involving stopovers.

Limiting the number of journeys to 5 implies an under-estimation of flying on the part of the respondents with the most air miles. Each of these 5 journeys is defined by a combination of departure, arrival, time spent at destination, and reason, but the number of flights that could be reported per journey is unlimited. Only $4 \%$ of respondents in $\mathrm{PhD}$-level positions reported a fifth journey in the table. Of this $4 \%, 60 \%$ reported more round-trip flights in the simplified question than in the table, for an average of 10.6 round trips, compared with 6.2. Overall, the underestimation of air travel in the table therefore appears to be limited.

The calculation of GHG emissions generated by air travel is subject to uncertainty depending on the way in which the radiative forcing resulting from factors other than $\mathrm{CO}_{2}$ (vapour trails, etc.) is considered. These factors are not taken into account by some GHG calculators, while the literature suggests that in all likelihood they double the emissions factors of flights [52]. Based on [24], we can select emissions factors of between $200 \mathrm{~g} \mathrm{CO}_{2} \mathrm{e} /$ passenger/km (for short-haul flights) and $300 \mathrm{~g} \mathrm{CO}_{2} \mathrm{e} /$ passenger/km (for long-haul flights). The detailed data on flights collected in the survey could be used to establish precise estimates of the emissions corresponding to each flight, but for the sake of simplicity we report distances, and only a rough estimate of the average emissions is provided here. 


\section{S3 Appendix. English translation of the Questionnaire}

Text of the invitation message :

Title message: [National survey] Research personnel faced with climate change

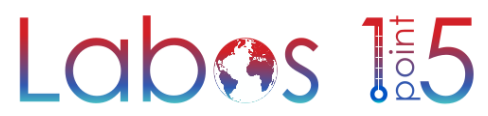

Dear colleague,

You have been selected to participate in the first large-scale survey of research staff's opinions and professional practices regarding climate change. The survey is open to all staff, regardless of their status, discipline and level of familiarity with environmental issues.

Your participation in this questionnaire is essential to reflect the diversity of practices and opinions of those who make up the world of research, and to find answers to environmental issues while respecting the multiplicity of points of view.

The answers to the questionnaire will be used anonymously in the framework of the future CNRS research group GDR-1point5. This questionnaire was designed by researchers within the multidisciplinary collective Labos 1point5, which analyses the impact of research staff activities on the environment and climate (see here on CNRS Info).

You can fill in the questionnaire at this address:

https://www.enquetes.mate-shs.cnrs.fr/index.php/113464?token=[\% user.gecos \%]

It is possible to answer in several times, by following again this same link.

The answers are strictly confidential (GDPR information notice here).

We thank you in advance for your participation. If you have any questions, please contact us at enquete@labos1point5.org.

Labos 1 point5 
Reminder message text :

Title message: [National survey: reminder] Research personnel faced with climate change

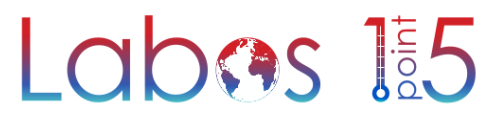

Dear colleague,

A week ago, you received a message inviting you to participate in a study on the opinions and professional practices of research staff in relation to climate change.

Some of you have told us that you are afraid that this is spam or phishing. We would like to reaffirm that this is a study coordinated by researchers, within the Labos 1.5 collective, which brings together research staff with the aim of analysing the impact of research activities on the environment and the climate. You will find more information on this collective in the June 2019 CNRS Info:

http://www.cnrs.fr/fr/cnrsinfo/recherche-et-environnement-le-collectif-labos-1point5-promeut-une-recherche-respo $\underline{\text { nsable }}$

We are sending you this invitation to participate in this study, reminding you that it is intended for all staff, regardless of their status, discipline or degree of familiarity with environmental issues. Your participation in this questionnaire is essential to reflect the diversity of practices and opinions of those who make up the world of research, and to find answers to environmental issues while respecting the multiplicity of points of view.

You can fill in the questionnaire at this address:

https://www.enquetes.mate-shs.cnrs.fr/index.php/113464?token=[\% user.gecos \%]

It is possible to answer them in several times, by following again this same link. You are of course free not to answer them or to answer only part of the questions if you wish.

The answers are strictly confidential (GDPR information notice here).

We thank you in advance for your participation. If you have any questions, please contact us at enquete@labos1point5.org.

For Labos 1point5,

Milan Bouchet-Valat (INED), Marianne Blanchard (Toulouse Jean-Jaurès University, CERTOP), Damien Cartron (CNRS, CMH), Jérôme Greffion (Paris Nanterre University, IDHES), Julien Gros (CNRS, LEST) 
Text of the reminder message for incomplete responses :

Title message: [National survey: reminder] Research personnel faced with climate change

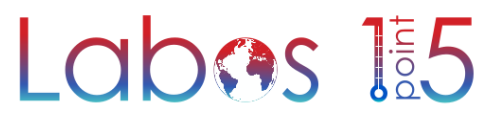

Dear colleague,

You have started to answer the questionnaire entitled "Researchers and climate change". Thank you very much for your time!

We have noticed that you have stopped filling in the questionnaire. However, complete answers to the questionnaire are very valuable to us. For example, the questions at the end allow us to understand your opinion on the concrete solutions to be implemented and to correctly understand your personal situation.

Also, if you have the opportunity, we would be very grateful if you could finish filling out the questionnaire. This will greatly improve the quality of our study.

You can continue to respond at this address:

https://www.enquetes.mate-shs.cnrs.fr/index.php/113464?token=[\% user.gecos \%]

Your previous answers have been retained.

If you have any questions, you can contact us at enquete@labos 1 point5.org.

For Labs 1 point5,

Milan Bouchet-Valat (INED), Marianne Blanchard (Toulouse Jean-Jaurès University, CERTOP), Damien Cartron (CNRS, CMH), Jérôme Greffion (Paris Nanterre University, IDHES), Julien Gros (CNRS, LEST) 


\section{First page of the questionnaire :}

This questionnaire is the first large-scale study of research personnel's opinions and professional practices regarding climate change. It is intended for all staff, regardless of their status, discipline and level of familiarity with environmental issues.

You have been selected at random from among all research personnel. Your participation in this questionnaire is essential to reflect the diversity of practices and opinions of those who make up the world of research, and to find answers to environmental issues while respecting the multiplicity of points of view.

The answers to the questionnaire will be used anonymously within the future CNRS research group GDR-1point5. This questionnaire was designed by researchers within the multidisciplinary collective Labos 1 point5, which brings together research personnel to analyse the impact of research activities on the environment and climate.

This questionnaire is about your professional situation and practices, as well as your representations and opinions on research and the environment. It includes some optional questions about personal opinions that are considered sensitive data under the European Data Protection Regulation (GDPR). You are free to continue without answering them, as with most questions. The answers are strictly confidential.

The questionnaire takes about 15-20 minutes to complete. It is possible to answer it in several times, by following the same link again. We thank you very much for your time!

The aggregated statistical results of this research will be disseminated in professional and scientific conferences, in professional and academic journals, in reports for authorities or research organizations, in media for the general public, and on social networks.

Initial results will be given at the end of the questionnaire. If you are interested in the more detailed results of the survey, you can ask to be kept informed.

Contact: enquete@labos1point5.org

The data collected in the context of this project have been declared to the CNRS Data Protection Officer at the following address CNRS-Service Protection des Données - 2 rue Jean Zay - 54500 - Vandoeuvre lès Nancy, dpd.demandes@cnrs.fr. You can access the information relating to this declaration here.

By checking this box, I acknowledge that I have read the information regarding data collection for this project and agree to participate in this study 
The questions marked with an * are not asked of staff not directly involved in research (BAP E-F-G-J).

\section{General information}

To begin, we would like to gather some information about your situation in the research community.

1. Are you... $\square$ a woman $\square$ a man $\square$ other

2. How old are you?

\begin{tabular}{|c|c|c|c|c|}
\hline $\begin{array}{l}\square \text { Under } 18 \text { years } \\
\square \text { 40-44 years }\end{array}$ & $\square 18-24$ years & $\square 25-29$ years & $\square$ 30-34 years & $\square 35-39$ years \\
\hline ears & $50-54$ years & $\square 55-59$ years & $\square 60-64$ years & $\square 65-69$ years \\
\hline
\end{tabular}

3. Currently, are you a PhD student? $\square$ Yes $\square$ No

4. What is your primary employment status? [REQUIRED]

$\square$ Civil servant

Permanent contract

Fixed-term contract

Self-employed

$\square$ Unemployed/no job $\quad \square$ Retired $\quad \square$ Other

5. What is (or was) your primary employment status? [MANDATORY]

\begin{tabular}{|r|r|r|r|r|}
\hline$\square$ Full professor & $\square$ Associate professor & $\square$ Adjunct lecturer & $\begin{array}{r}\square \text { PhD student } \\
\text { with funding }\end{array}$ \\
doctoral contract
\end{tabular}

6. IF PhD STUDENT! = YES and (UNEMPLOYED (question 4) or RESEARCH ASSISTANT/PROJECT

MANAGER/TECHNICIAN/TECHNICAL ASSISTANT/OTHER (question 5)) : Are you currently associated with (primarily or secondarily) or member of a public research institution? [REQUIRED]

$\square$ Yes $\quad \square$ No

7. FOR PhD STUDENTS OR RESEARCHERS: What is your main research discipline? Please choose from the following National Council of Universities (CNU) sections. You can type the first characters or the number to start a search. (list of CNU sections)

FOR SUPPORT PERSONNEL: To which branch of professional activity (BAP) do you belong? (list BAP + Other + DK) [MANDATORY]

FOR SUPPORT PERSONNEL and OTHER NON-PhD STUDENTS: Are you close to one of the following disciplines? Please choose among the CNU sections. You can type the first characters or the number to launch a search. (list of $\mathrm{CNU}$ sections)

Filter for those in BAP E-F-G-J (excluding A-B-C-D who are involved in research activities): short questionnaire (questions marked with an * are skipped) 
8. If civil servant/permanent contract/fixed-term contract: What is your main employer?

CNRS $\square$ A university $\square$ A grande école or grand établissement

Inserm $\square$ Inrae $\square$ Inria $\square$ IRD $\square$ Ined

CEA $\square$ CNES $\square$ ONERA $\square$ Cirad $\square$ Ifremer

Another public institution

A company

Other:

9. What institutions is your main laboratory (or of the unit or team in which you work) affiliated with? (Several answers are possible.)

CNRS $\square$ A university $\square$ A grande école or grand établissement

Inserm $\square$ Inrae $\square$ Inria $\square$ IRD $\square$ Ined

CEA $\square$ CNES $\square$ ONERA $\square$ Cirad $\square$ Ifremer

Another public institution

A company

Other :

\section{Your position on the environment and research}

We'll now talk about your position on current environmental issues and how they relate to your research.

10. Do you think the climate of the planet is changing (rise in temperatures in the last century)?

Yes, definitely $\quad \square$ Yes, probably $\quad \square$ No, probably not $\quad \square$ No, definitely not $\quad \square$ No opinion

11. If yes climate change. In your opinion, are human activities the cause of this climate change?

No, they play no role $\quad \square$ Yes, they play a small role

Yes, they play a major role $\square$ Yes, they are the only cause $\quad \square$ No opinion

12. If yes climate change. To what degree are you concerned about climate change?

$\square$ Not at all concerned $\quad \square$ Slightly concerned $\quad \square$ Somewhat concerned

$\square$ Very concerned $\quad \square$ Extremely concerned $\quad \square$ No opinion

13. If yes climate change. Are you more or less concerned than 5 years ago?

$\square$ Much more $\square$ Somewhat more $\square$ Neither more nor less $\quad \square$ Somewhat less $\square$ Much less $\square$ No opinion

14. Regardless of your field of work, are you involved in research related to ecology, the environment, or climate?* $\square$ Yes $\quad \square$ No, but I have been in the past $\quad \square$ No

15. Have you ever:* 


\begin{tabular}{|l|l|l|l|}
\hline & Yes, I already have & $\begin{array}{l}\text { I thought } \\
\text { about it }\end{array}$ & No \\
\hline $\begin{array}{l}\text { Reoriented your research towards themes more related to } \\
\text { ecology, the environment or climate }\end{array}$ & $\square$ & $\square$ & $\square$ \\
\hline $\begin{array}{l}\text { Forgone research programs/themes due to their negative } \\
\text { impact on the environment }\end{array}$ & $\square$ & $\square$ & $\square$ \\
\hline
\end{tabular}

16. Do you think that climate urgency calls for profound changes in the practice of our professions?
$\square$ Yes, strongly agree
$\square$ Yes, somewhat agree
No, somewhat disagree
$\square$ No, strongly disagree
No opinion

Your practices and those of your laboratory (management of equipment, energy, etc.)

We will now discuss your professional practices and those of your laboratory to limit the impact of research on the environment.

17. In your laboratory (or in the unit or team in which you work):

\begin{tabular}{|l|l|l|l|l|l|}
\hline & $\begin{array}{l}\text { I don't } \\
\text { know }\end{array}$ & Yes & No & $\begin{array}{l}\text { No, but the } \\
\text { issue has been } \\
\text { discussed }\end{array}$ & $\begin{array}{l}\text { Not } \\
\text { concerned }\end{array}$ \\
\hline You can recycle your paper waste & $\square$ & $\square$ & $\square$ & $\square$ & $\square$ \\
\hline $\begin{array}{l}\text { You are encouraged to take the train rather than } \\
\text { the plane even if it is more expensive or longer }\end{array}$ & $\square$ & $\square$ & $\square$ & $\square$ & $\square$ \\
\hline $\begin{array}{l}\text { There is a charter, a working group or a person } \\
\text { designated to reduce the ecological footprint of } \\
\text { research activities }\end{array}$ & $\square$ & $\square$ & $\square$ & $\square$ & $\square$ \\
\hline
\end{tabular}


18. In your laboratory (or in the unit or team in which you work), collective measures have been implemented to:

\begin{tabular}{|l|l|l|l|l|l|}
\hline & $\begin{array}{l}\text { I don't } \\
\text { know }\end{array}$ & Yes & No & $\begin{array}{l}\text { No, but the } \\
\text { issue has been } \\
\text { discussed }\end{array}$ & $\begin{array}{l}\text { Not } \\
\text { concerned }\end{array}$ \\
\hline $\begin{array}{l}\text { Limit the environmental impact of drinks and buffets } \\
\text { (reducing plastic waste, offering organic, local or } \\
\text { vegetarian menus, etc.) }\end{array}$ & $\square$ & $\square$ & $\square$ & $\square$ & $\square$ \\
\hline $\begin{array}{l}\text { Limit the generation of waste from experiments } \\
\text { Reduce greenhouse gas emissions from } \\
\text { observation and data collection trips }\end{array}$ & $\square$ & $\square$ & $\square$ & $\square$ & $\square$ \\
\hline $\begin{array}{l}\text { Reduce the power consumption of servers } \\
\text { (storage, calculation...) }\end{array}$ & $\square$ & $\square$ & $\square$ & $\square$ & $\square$ \\
\hline
\end{tabular}

19. As an individual, when technically possible:

\begin{tabular}{|l|l|l|l|l|}
\hline & $\begin{array}{l}\text { Always } \\
\text { or often }\end{array}$ & $\begin{array}{l}\text { Someti } \\
\text { mes }\end{array}$ & $\begin{array}{l}\text { Rarely or } \\
\text { never }\end{array}$ & $\begin{array}{l}\text { I don't have } \\
\text { control, } \\
\text { not concerned }\end{array}$ \\
\hline $\begin{array}{l}\text { Do you turn off or suspend the computer you use at } \\
\text { work when you leave the office at night? }\end{array}$ & $\square$ & $\square$ & $\square$ & $\square$ \\
\hline $\begin{array}{l}\text { During the winter, do you turn down the heating in } \\
\text { your office outside of working hours? }\end{array}$ & $\square$ & $\square$ & $\square$ & $\square$ \\
\hline $\begin{array}{l}\text { Do you limit the sending of large attachments in your } \\
\text { emails? }\end{array}$ & $\square$ & $\square$ & $\square$ & $\square$ \\
\hline Do you print on both sides? & $\square$ & $\square$ & $\square$ & $\square$ \\
\hline
\end{tabular}


\#\# MODULE 2: IT EQUIPMENT

20. For vour work, you use (leave blank the boxes that do not concern you or that would be 0):

\begin{tabular}{|l|l|l|l|}
\hline & Number & $\begin{array}{r}\text { How many are } \\
\text { less than 5 } \\
\text { years old? }\end{array}$ & $\begin{array}{r}\text { How many do you } \\
\text { consider essential? }\end{array}$ \\
\hline Shared computers in the lab & & & \\
\hline $\begin{array}{l}\text { Personal desktop computers purchased with } \\
\text { professional funding }\end{array}$ & & & \\
\hline Personal desktop computers purchased by you & & & \\
\hline $\begin{array}{l}\text { Personal laptops purchased with professional } \\
\text { funding }\end{array}$ & & & \\
\hline Personal laptops purchased by you & & & \\
\hline Tablets purchased with professional funding & & & \\
\hline Tablets purchased by you & & & \\
\hline
\end{tabular}

21. The last time you changed the computer you use for your work, for what reasons did you do so? (Multiple answers possible.)

$\square$ I never changed my computer for professional use

$\square$ I got a new job contract $\quad \square$ It was stolen, I lost it

$\square$ It didn't work at all anymore $\quad \square$ It didn't work very well anymore

$\square$ It wasn't powerful enough $\quad \square$ It couldn't be updated anymore

$\square$ I wanted a new one $\quad \square$ I wanted a better one (better autonomy, screen, etc.)

$\square$ It was proposed to me/l had the opportunity to do it $\quad \square$ I was forced to do it

$\square$ Other 
22. In the past 5 years, have you ever spent money on the following items to finish a budget leftover when it was not really essential (for you or others)?

\begin{tabular}{|l|r|r|r|}
\hline & Yes & No & $\begin{array}{r}\text { I haven't had to use } \\
\text { any leftover budget }\end{array}$ \\
\hline Funding for air travel & $\square$ & $\square$ & $\square$ \\
\hline Purchase of computers, monitors or tablets & $\square$ & $\square$ & $\square$ \\
\hline
\end{tabular}

23. If in Science and technology or Life and environmental sciences, or if in BAP A, B, C or E: Do you regularly use the following equipment to perform your scientific experiments and observations? (Several answers are possible.)

Very large, energy-intensive shared research infrastructures (particle accelerator, radio telescope, oceanographic ship, aircraft, etc.)

$\square$ Large computing infrastructure (supercomputer or data center)

Extensive non-laboratory experimental setups (fields, greenhouses, farms, etc.) or an animal house

Large, expensive equipment (MRI, positron emission tomography, scanning microscope, frequency comb, etc.)

Expensive equipment (oscilloscope, centrifuge, fume hood, freezer, laser, electromagnet, cryostat, vacuum pump, mass spectrometer, optical microscope, photomultiplier, etc.)

$\square$ Small laboratory equipment (glassware, small electronics, etc.)

$\square$ None of the above

24. Over the past 5 years, would you say that your greenhouse gas emissions in the following areas have...

\begin{tabular}{|l|r|r|r|r|r|r|r|}
\hline & $\begin{array}{r}\text { Increased } \\
\text { sharply }\end{array}$ & $\begin{array}{r}\text { Increased } \\
\text { somewhat }\end{array}$ & $\begin{array}{r}\text { Been } \\
\text { more } \\
\text { or less } \\
\text { stable }\end{array}$ & $\begin{array}{r}\text { Decreas } \\
\text { ed } \\
\text { somewh } \\
\text { at }\end{array}$ & $\begin{array}{r}\text { Decrea } \\
\text { sed } \\
\text { sharply }\end{array}$ & $\begin{array}{r}\text { Not } \\
\text { concerne } \\
\text { d }\end{array}$ \\
$\begin{array}{r}\text { don't } \\
\text { know }\end{array}$ \\
\hline $\begin{array}{l}\text { Air travel for conferences, } \\
\text { meetings, and congresses }\end{array}$
\end{tabular}


Your transportation for professional purposes

Now let's talk about your use of transportation for professional purposes, looking first at your use of air travel and its reasons.

25. For the year 2019 (January 1 to December 31), approximately how many round trips flights did you make for professional purposes excluding commuting? For a one-way trip, indicate 0.5 round trips.

- round-trip flights

IF > 0: For approximately how many hours of flying in total?

$\square$ From $1 \mathrm{~h}$ to $10 \mathrm{~h} \quad \square$ From $11 \mathrm{~h}$ to $20 \mathrm{~h} \quad \square$ From $20 \mathrm{~h}$ to $50 \mathrm{~h} \quad \square$ Over $50 \mathrm{~h}$

26. IF = 0: In the previous two years (2017 and 2018), did you fly for professional purposes excluding commuting?

$\square$ Yes, for more than 10 hours in total $\quad \square$ Yes, for less than 10 hours in total $\quad \square$ No 


\section{\#\#\# MODULE 1: FLIGHTS}

27. If you flew in $\mathbf{2 0 1 9}$ (if not, go to the next question), please describe in the following table your first 5 round-trip flights by plane in 2019, grouping together those made several times for the same reasons. Indicate the French names of the cities (e.g. Londres rather than London), using the suggestions that appear when possible (these names will be used to calculate the distance of the flight). For a one-way trip, enter 0.5 round trips.

\begin{tabular}{|c|c|c|c|c|c|c|}
\hline & $\begin{array}{l}\text { City of } \\
\text { departur } \\
\text { e } \\
\text { (take-off) }\end{array}$ & $\begin{array}{l}\text { City of } \\
\text { arrival } \\
\text { (final } \\
\text { landing) }\end{array}$ & $\begin{array}{l}\text { Number of days } \\
\text { worked on site } \\
\text { - Less than two } \\
\text { days } \\
\text { - From two days } \\
\text { to one week } \\
\text { - From more } \\
\text { than a week to a } \\
\text { month } \\
\text { - More than one } \\
\text { month }\end{array}$ & $\begin{array}{l}\text { Primary reason for travel } \\
\text { - Conference, presentation } \\
\text { - Research stay } \\
\text { - Meeting, workshop } \\
\text { - Teaching, training, summer } \\
\text { school } \\
\text { - Fieldwork, production and data } \\
\text { collection } \\
\text { - Getting funding } \\
\text { - Evaluation of research } \\
\text { - Jury } \\
\text { - Other }\end{array}$ & $\begin{array}{l}\text { Secondary reason for travel (if } \\
\text { any) } \\
\text { - None } \\
\text { - Conference, presentation } \\
\text { - Research stay } \\
\text { - Meeting, workshop } \\
\text { - Teaching, training, summer } \\
\text { school } \\
\text { - Fieldwork, production and } \\
\text { data collection } \\
\text { - Getting funding } \\
\text { - Evaluation of research } \\
\text { - Jury } \\
\text { - Other }\end{array}$ & $\begin{array}{l}\text { Number of } \\
\text { round trips } \\
\text { made }\end{array}$ \\
\hline Journey 1 & & & & & & trips \\
\hline Journey 2 & & & & & & trips \\
\hline Journey 3 & & & & & & $\overline{t r i p s}^{- \text {round }}$ \\
\hline Journey 4 & & & & & & trips \\
\hline Journey 5 & & & & & & $\overline{\text { trips }}^{\text {round }}$ \\
\hline
\end{tabular}

28. IF > 0: Of these flights, what proportion did you fly in premium or business class?
$\square$ Zero
Less than a quarter
Between a quarter and half
More than half

29. If > 0: In 2019, did you fly for a work trip that takes less than 6 hours by train (excluding commuting)?
$\square$ Yes
$\square$ No $\square$ I don't know

30. If yes: What are your main reasons for flying in these cases? (Several answers possible.)
$\square$ Flying is faster
$\square$ Flying is cheaper
Flying is more convenient
$\square$ I like flying
$\square$ Flying saves me an overnight stay
$\square$ Administrative rules encourage me to fly 
$\square$ It allows me to accumulate miles

$\square$ I do not think about it

Other (specify:

31. In the last 5 years, have you, for environmental reasons, taken the train rather than the plane in a professional context when the journey was longer?

Yes, several times $\quad \square$ Yes, once $\square$ No, but I thought about it $\square$ No

\section{\#\#\# END OF MODULE 1: FLIGHTS}

32. Have you ever attended a conference/symposium abroad?

Yes, within the last 5 years

Yes, but more than 5 years ago -> skip the next question

No -> skip the next two questions

33. If yes in the last 5 years: approximately how many times in the last 5 years?

Less than once a year $\square$ Once a year

$\square$ Twice a year $\quad \square$ Three times a year $\quad \square$ More than three times a year

34. If yes: Did the last such event in which you participated allow you to:

\begin{tabular}{|l|l|l|l|l|l|}
\hline & $\begin{array}{l}\text { Yes, to a } \\
\text { great } \\
\text { extent }\end{array}$ & $\begin{array}{l}\text { Yes, } \\
\text { somewhat }\end{array}$ & $\begin{array}{l}\text { No, not } \\
\text { really } \\
\text { all }\end{array}$ & $\begin{array}{l}\text { No, not at } \\
\text { opinion }\end{array}$ \\
\hline Advance in your work (comments/exchanges) & $\square$ & $\square$ & $\square$ & $\square$ & $\square$ \\
\hline Develop/maintain your international networks & $\square$ & $\square$ & $\square$ & $\square$ & $\square$ \\
\hline $\begin{array}{l}\text { Maintain/strengthen professional or friendly ties } \\
\text { with colleagues working in France }\end{array}$ & $\square$ & $\square$ & $\square$ & $\square$ & $\square$ \\
\hline Improve your CV & $\square$ & $\square$ & $\square$ & $\square$ & $\square$ \\
\hline Visit, do tourism & $\square$ & $\square$ & $\square$ & $\square$ & $\square$ \\
\hline
\end{tabular}


\#\#\# MODULE 1: FLIGHTS

35. In 2019, did you forego one or more professional trips abroad (including deciding not to apply for a conference) for the following reasons?

\begin{tabular}{|l|r|r|r|}
\hline & $\begin{array}{r}\text { Yes, that } \\
\text { was the } \\
\text { main reason }\end{array}$ & $\begin{array}{r}\text { Yes, but that } \\
\text { was a } \\
\text { secondary } \\
\text { reason }\end{array}$ \\
\hline Conflict with private commitments (family, appointments...) & $\square$ & $\square$ & $\square$ \\
\hline Conflict with other professional commitments & $\square$ & $\square$ & $\square$ \\
\hline Comfort and health reasons (travel time, jet lag, fatigue, etc.) & $\square$ & $\square$ & $\square$ \\
\hline Environmental considerations & $\square$ & $\square$ \\
\hline Difficulties in financing the trip & $\square$ & $\square$ \\
\hline The possibility of replacing travel with video conferencing & $\square$ \\
\hline
\end{tabular}

\#\#\# END OF MODULE 1: FLIGHTS

\#\#\# MODULE 2: COMMUTING

36. Under normal circumstances (before the lockdown), on average, how many days do you work only from home? Do not include any days worked on weekends.
Never
$\square$ Less than 1 day per week
1 day per week
2 days per week
3 days per week
$\square$ days per week
5 days per week 
Let's talk about your commute to work, in normal times (before the lockdown).

37. Before the lockdown, how much time did you spend on average per week on the following transport to and from work? Enter the sum of all trips to and from work, including long-distance trips. Leave blank the boxes that do not apply to you or that would be 0.

\begin{tabular}{|l|l|l|}
\hline & hours per week & minutes per week \\
\hline Bus, subway, tramway, RER & & \\
\hline High-speed train & & \\
\hline Other trains & & \\
\hline Alone in a car & & \\
\hline Multiple people in a car & & \\
\hline Motorcycle, motor scooter & & \\
\hline Bicycle or kick scooter & & \\
\hline Walk & & \\
\hline Airplane & & \\
\hline
\end{tabular}

38. If alone in a car on one of the trips:

For trips you make alone in your car, why don't you carpool? (Multiple answers possible.)

$\square$ I value the flexibility of my hours $\quad \square$ I have too atypical or irregular hours

$\square$ It takes too much organization

$\square$ I have to drop the kids off at school

$\square$ I haven't found anyone with a similar route and hours

$\square$ I'm afraid to carpool with someone I don't get along with

$\square$ I'm afraid of the unreliability of others

$\square$ I don't know how to find a carpooler

The trip is too short

Other:

39. If several people in a car: With whom do you usually make multi-person car trips?

$\square$ With my spouse $\square$ With colleagues $\quad \square$ With friends $\quad \square$ Other 
Video and audio conferencing

We would now like to discuss your use of video and audio conferencing. By this we mean remote exchanges between at least 3 people, whatever the means used.

40. Before the lockdown, what was your usual use of video or audio conferencing in a professional context?

$\square$ Never

$\square$ Less than once a month $\square 1$ to 3 times a month

1 to 4 times a week

$\square 1$ to 2 times a day

$\square$ More than 2 times a day

41. During the lockdown, what was your use of video or audio conferencing in a professional context?

$\square$ Never

$\square$ Less than once a month $\square 1$ to 3 times a month

1 to 4 times a week

$\square 1$ to 2 times a day

More than 2 times a day

42. Currently, in your experience, for which uses do you think video or audio conferencing is suitable?

\begin{tabular}{|l|r|r|r|r|r|r|}
\hline & $\begin{array}{r}\text { I have } \\
\text { never } \\
\text { tested }\end{array}$ & $\begin{array}{r}\text { Very } \\
\text { suitable }\end{array}$ & $\begin{array}{r}\text { Rather } \\
\text { suitable }\end{array}$ & $\begin{array}{r}\text { Rather } \\
\text { unsuitable }\end{array}$ & $\begin{array}{r}\text { Not } \\
\text { suitabl } \\
\text { e at all }\end{array}$ \\
opinion \\
\hline Work meeting of 3 to 5 people & $\square$ & $\square$ & $\square$ & $\square$ & $\square$ \\
\hline Work meeting of 15 people & $\square$ & $\square$ & $\square$ & $\square$ & $\square$ \\
\hline Oral examination (recruitment, thesis...) & $\square$ & $\square$ & $\square$ & $\square$ & $\square$ \\
\hline Seminar presentation & $\square$ & $\square$ & $\square$ & $\square$ & $\square$ \\
\hline $\begin{array}{l}\text { Conference or congress with several } \\
\text { presentations }\end{array}$ & $\square$ & $\square$ & $\square$ & $\square$ & $\square$ \\
\hline
\end{tabular}

43. Since the lockdown, has your experience made you more or less supportive of video or audio conferencing?

$\square$ Much more favorable $\quad \square$ Somewhat more favorable $\square$ My opinion hasn't changed

$\square$ Somewhat less favorable $\quad \square$ Much less favorable $\quad \square$ No opinion 
44. Let's imagine a one-day meeting, located 2 hours from your home by car. Could the following reasons lead you to choose video or audio conferencing over travel? If you don't drive, suppose a colleague drives you.

\begin{tabular}{|l|r|r|r|r|r|}
\hline & $\begin{array}{r}\text { Yes, to a } \\
\text { great } \\
\text { extent }\end{array}$ & $\begin{array}{r}\text { Yes, } \\
\text { somewh } \\
\text { at }\end{array}$ & $\begin{array}{r}\text { No, not } \\
\text { really }\end{array}$ & No, not at all \\
opinion \\
\hline Save time & $\square$ & $\square$ & $\square$ & $\square$ \\
\hline Limit travel fatigue & $\square$ & $\square$ & $\square$ & $\square$ \\
\hline Limit travel costs & $\square$ & $\square$ & $\square$ & $\square$ \\
\hline $\begin{array}{l}\text { Balance your family constraints with your } \\
\text { professional activity }\end{array}$ & $\square$ & $\square$ & $\square$ & $\square$ \\
\hline Limit your greenhouse gas emissions & $\square$ & $\square$ & $\square$ & $\square$ \\
\hline $\begin{array}{l}\text { Be able to do other things at the same time as the } \\
\text { meeting }\end{array}$ & $\square$ & $\square$ & $\square$ & $\square$ & $\square$ \\
\hline $\begin{array}{l}\text { Easily bring together many people who are far } \\
\text { apart geographically }\end{array}$ & $\square$ & $\square$ & $\square$ & $\square$ \\
\hline
\end{tabular}

45. Let's always imagine a one-day meeting, located 2 hours away from your home by car. Could the following issues prevent you from choosing video or audio conferencing over travel?

\begin{tabular}{|l|r|r|r|r|r|}
\hline & $\begin{array}{r}\text { Yes, to a } \\
\text { great } \\
\text { extent }\end{array}$ & $\begin{array}{r}\text { Yes, } \\
\text { somewh } \\
\text { at }\end{array}$ & $\begin{array}{r}\text { No, not } \\
\text { really }\end{array}$ & No, not at all & $\begin{array}{r}\text { No } \\
\text { opinion }\end{array}$ \\
\hline It generates technical problems & $\square$ & $\square$ & $\square$ & $\square$ & $\square$ \\
\hline It limits the relational aspects & $\square$ & $\square$ & $\square$ & $\square$ & $\square$ \\
\hline $\begin{array}{l}\text { It makes it difficult to write or draw while } \\
\text { discussing (diagrams, formulas, equations...) }\end{array}$ & $\square$ & $\square$ & $\square$ & $\square$ & $\square$ \\
\hline $\begin{array}{l}\text { It's more tiring to follow than a face-to-face } \\
\text { meeting }\end{array}$ & $\square$ & $\square$ & $\square$ & & $\square$ \\
\hline
\end{tabular}




\section{Concrete solutions in research}

We would now like to hear your views on concrete solutions that could be put in place to reduce greenhouse gas emissions from research activities.

46. France has committed to reducing its greenhouse gas emissions by one third by 2030 . In this respect, do you think that :

Public research must set an example by reducing greenhouse gas emissions by more than one-third

Public research must reduce its greenhouse gas emissions by around one-third

Because of its role, public research may benefit from an exemption, i.e. provide lesser efforts in terms of reducing greenhouse gas emissions

47. If civil servant, permanent contract or self-employed: Are you willing to reduce your greenhouse gas emissions by 2030 in the following areas? This does not take into account reductions you have already made in the past.

\begin{tabular}{|l|r|r|r|r|r|r|}
\hline & $\begin{array}{r}\text { Yes, by } \\
\text { at least } \\
\text { one-third }\end{array}$ & $\begin{array}{r}\text { Yes, but } \\
\text { by less } \\
\text { than } \\
\text { one-third }\end{array}$ & $\begin{array}{r}\text { No, as they } \\
\text { are already } \\
\text { very low }\end{array}$ & No & $\begin{array}{r}\text { Not } \\
\text { concerned }\end{array}$ & $\begin{array}{r}\text { No } \\
\text { opinion }\end{array}$ \\
\hline $\begin{array}{l}\text { Flights for conferences, meetings, } \\
\text { and congresses }\end{array}$ & $\square$ & $\square$ & $\square$ & $\square$ & $\square$ \\
\hline $\begin{array}{l}\text { Travel for fieldwork, observation or } \\
\text { data collection (by plane, car or boat) }\end{array}$ & $\square$ & $\square$ & $\square$ & $\square$ & \\
\hline $\begin{array}{l}\text { Scientific experiments and } \\
\text { observations (excluding travel)* }\end{array}$ & $\square$ & $\square$ & $\square$ & $\square$ \\
\hline $\begin{array}{l}\text { IT equipment and its replacement } \\
\text { rates }\end{array}$ & $\square$ & $\square$ & $\square$ & $\square$ & $\square$ \\
\hline $\begin{array}{l}\text { If car, motorcycle/scooter or plane: } \\
\text { Commuting to work by car, motorbike, } \\
\text { scooter or plane }\end{array}$ & $\square$ & $\square$ & $\square$ & $\square$ & $\square$ \\
\hline
\end{tabular}

48. If civil servant, permanent contract or self-employed AND if using experimental equipment: Are you willing to reduce by 2030 the greenhouse gas emissions associated with the production and operation of equipment for your scientific experiments and observations by the following means?

\begin{tabular}{|l|r|r|r|r|r|r|}
\hline & $\begin{array}{r}\text { Yes, by } \\
\text { more } \\
\text { than } \\
\text { one-third }\end{array}$ & $\begin{array}{r}\text { Yes, but } \\
\text { by less } \\
\text { than } \\
\text { one-third }\end{array}$ & $\begin{array}{r}\text { No, as they } \\
\text { are already } \\
\text { very low }\end{array}$ & No & $\begin{array}{r}\text { Not } \\
\text { concerned }\end{array}$ & $\begin{array}{r}\text { No } \\
\text { opinion }\end{array}$ \\
\hline
\end{tabular}




\begin{tabular}{|l|r|r|r|r|r|r|}
\hline $\begin{array}{l}\text { Using equipment less frequently or } \\
\text { less intensively }\end{array}$ & $\square$ & $\square$ & $\square$ & $\square$ & $\square$ \\
\hline $\begin{array}{l}\text { Using or developing simpler systems } \\
\text { (low-tech) }\end{array}$ & $\square$ & $\square$ & $\square$ & $\square$ & & $\square$ \\
\hline $\begin{array}{l}\text { Using less equipment in experimental } \\
\text { setups }\end{array}$ & $\square$ & $\square$ & $\square$ & $\square$ & $\square$ \\
\hline $\begin{array}{l}\text { Replacing the equipment at a slower } \\
\text { rate }\end{array}$ & $\square$ & $\square$ & $\square$ & $\square$ & & $\square$ \\
\hline
\end{tabular}

49. If using experimental equipment: In your opinion, what would be the risks of a policy on reducing the greenhouse gas emissions generated by the production and operation of equipment for scientific experiments and observations?

\begin{tabular}{|c|c|c|c|c|c|}
\hline & $\begin{array}{l}\text { It is likely } \\
\text { and it is a } \\
\text { problem }\end{array}$ & $\begin{array}{l}\text { It is likely, } \\
\text { but it is not } \\
\text { a problem }\end{array}$ & It is unlikely & $\begin{array}{r}\text { No } \\
\text { opinion }\end{array}$ & $\begin{array}{r}\text { Not } \\
\text { concerne } \\
d\end{array}$ \\
\hline $\begin{array}{l}\text { Reduce the quality of your work (or that of } \\
\text { your team) }\end{array}$ & $\square$ & $\square$ & $\square$ & $\square$ & $\square$ \\
\hline Require you to change research themes & $\square$ & $\square$ & $\square$ & $\square$ & $\square$ \\
\hline Reduce your access to funding & $\square$ & $\square$ & $\square$ & $\square$ & $\square$ \\
\hline Set you back compared with rival teams & $\square$ & $\square$ & $\square$ & $\square$ & $\square$ \\
\hline Reduce your number of publications & $\square$ & $\square$ & $\square$ & $\square$ & $\square$ \\
\hline
\end{tabular}

50. In your opinion, what would be the risks of implementing a policy on the reduction of professional air travel in research? *

\begin{tabular}{|l|r|r|r|r|r|}
\hline & $\begin{array}{c}\text { It is likely } \\
\text { and it is a } \\
\text { problem } \\
\text { but it is } \\
\text { not a } \\
\text { problem }\end{array}$ & $\begin{array}{c}\text { It is likely } \\
\text { It is unlikely }\end{array}$ & $\begin{array}{c}\text { No } \\
\text { opinion } \\
\text { concern } \\
\text { ed }\end{array}$ \\
\hline $\begin{array}{l}\text { Reduce the quality of your work (or that of your } \\
\text { team) }\end{array}$ & $\square$ & $\square$ & $\square$ & $\square$ \\
\hline Reduce your access to funding & $\square$ & $\square$ & $\square$ & $\square$ & $\square$ \\
\hline $\begin{array}{l}\text { Reduce the dissemination of your work (or that of } \\
\text { your team) }\end{array}$ & $\square$ & $\square$ & $\square$ & $\square$ & $\square$ \\
\hline
\end{tabular}




\begin{tabular}{|l|r|r|r|r|r|}
\hline $\begin{array}{l}\text { Hinder your access to some field sites or the } \\
\text { collection/production of certain data }\end{array}$ & $\square$ & $\square$ & $\square$ & $\square$ \\
\hline $\begin{array}{l}\text { Reduce some of the advantages offered to you by } \\
\text { your profession (like travelling and discovering } \\
\text { other countries...) }\end{array}$ & $\square$ & $\square$ & $\square$ & $\square$ & $\square$ \\
\hline Isolate French research from the rest of the world & $\square$ & $\square$ & $\square$ & $\square$ & $\square$ \\
\hline Hinder the integration of young researchers & $\square$ & $\square$ & $\square$ & $\square$ \\
\hline $\begin{array}{l}\text { Increase bureaucracy (enforcement, evaluation } \\
\text { criteria...) }\end{array}$ & $\square$ & $\square$ & $\square$ & $\square$ & $\square$ \\
\hline
\end{tabular}


51. What actions should research institutions and laboratories take to reduce their greenhouse gas emissions?

\begin{tabular}{|c|c|c|c|c|}
\hline & $\begin{array}{l}\text { It is a } \\
\text { priority }\end{array}$ & $\begin{array}{r}\text { It is } \\
\text { secondary }\end{array}$ & $\begin{array}{r}\text { It should not } \\
\text { be } \\
\text { implemented }\end{array}$ & $\begin{array}{r}\text { No } \\
\text { opinion }\end{array}$ \\
\hline $\begin{array}{l}\text { Finance train tickets even if more expensive or } \\
\text { requires a longer stay }\end{array}$ & $\square$ & $\square$ & $\square$ & $\square$ \\
\hline Finance carbon offsetting initiatives & $\square$ & $\square$ & $\square$ & $\square$ \\
\hline $\begin{array}{l}\text { Regularly draft and disseminate detailed carbon } \\
\text { assessments }\end{array}$ & $\square$ & $\square$ & $\square$ & $\square$ \\
\hline Impose a cap on the number of flights per person & $\square$ & $\square$ & $\square$ & $\square$ \\
\hline $\begin{array}{l}\text { Add carbon emissions to the main selection criteria for } \\
\text { project funding }\end{array}$ & $\square$ & $\square$ & $\square$ & $\square$ \\
\hline $\begin{array}{l}\text { Reduce the importance of conferences and } \\
\text { presentations abroad in career assessments }\end{array}$ & $\square$ & $\square$ & $\square$ & $\square$ \\
\hline $\begin{array}{l}\text { Prohibit air travel when the same journey takes less } \\
\text { than } 6 \text { hours by train }\end{array}$ & $\square$ & $\square$ & $\square$ & $\square$ \\
\hline $\begin{array}{l}\text { Do not renew functional computer equipment before a } \\
\text { minimum of } 5 \text { years of age }\end{array}$ & $\square$ & $\square$ & $\square$ & $\square$ \\
\hline $\begin{array}{l}\text { When replacing equipment, prefer those consuming } \\
\text { less energy even if more expensive }\end{array}$ & $\square$ & $\square$ & $\square$ & $\square$ \\
\hline $\begin{array}{l}\text { When organising events, prefer service providers } \\
\text { offering local or vegetarian food }\end{array}$ & $\square$ & $\square$ & $\square$ & $\square$ \\
\hline
\end{tabular}

52. If alone or with several people in a car: If carpooling was organized at the level of your laboratory or more widely at your site, would you be willing to use it for your home-work trips?

$\square$ Yes, definitely $\quad \square$ Yes, probably $\quad \square$ No, probably not $\square$ No, definitely not

\section{Your personal position on ecology in general}

To better understand your views on research and the environment, we would now like to gather your more general opinion on ecology and its role in politics. Feel free to skip any questions you do not wish to answer.

53. In the last 10 years, have you ever... 


\begin{tabular}{|l|l|l|l|}
\hline & Yes & No & $\begin{array}{l}\text { I do not wish } \\
\text { to answer }\end{array}$ \\
\hline Calculated all or part of your greenhouse gas emissions (carbon footprint) & $\square$ & $\square$ & $\square$ \\
\hline $\begin{array}{l}\text { Consulted an Intergovernmental Panel on Climate Change (IPCC) report or } \\
\text { summary (not a news article) }\end{array}$ & $\square$ & $\square$ & $\square$ \\
\hline Joined or made a donation to an environmental association & $\square$ & $\square$ & $\square$ \\
\hline Participated in a climate march & $\square$ & $\square$ & $\square$ \\
\hline Gave a decisive importance to ecology in a vote & $\square$ & $\square$ & $\square$ \\
\hline
\end{tabular}

54. How many round trips did you make by air in 2019 in a personal setting?

$\square$ No round trips $\quad \square 1$ or 2 round trips $\square 3$ or 4 round trips $\quad \square$ More than 5 round trips

55. Have you, in the last 5 years, changed your practices regarding air travel in a personal setting?

$\square$ No $\quad \square$ Yes, I take it much less $\quad \square$ Yes, I take it a little less

$\square$ Yes, I take it a little more $\quad \square$ Yes, I take it a lot more

56. In the past 5 years, have you, for environmental reasons, made efforts to reduce or keep low your personal consumption of some of the following items: clothing, meat, high-tech equipment, energy needed to heat your home?

Yes, a lot $\square$ Yes, a little $\square$ No 
57. To what extent do you agree with the following statements?

\begin{tabular}{|l|r|r|r|r|r|}
\hline & $\begin{array}{r}\text { Strongly } \\
\text { agree }\end{array}$ & $\begin{array}{c}\text { Somewh } \\
\text { at agree }\end{array}$ & $\begin{array}{c}\text { Somewha } \\
\text { t disagree }\end{array}$ & $\begin{array}{r}\text { Strongly } \\
\text { disagree }\end{array}$ & $\begin{array}{r}\text { No } \\
\text { opinion }\end{array}$ \\
\hline $\begin{array}{l}\text { Most environmental problems can be solved by } \\
\text { applying more and better technology }\end{array}$ & $\square$ & $\square$ & $\square$ & $\square$ \\
\hline $\begin{array}{l}\text { Protecting the environment is more important } \\
\text { than protecting economic growth }\end{array}$ & $\square$ & $\square$ & $\square$ & $\square$ & $\square$ \\
\hline $\begin{array}{l}\text { There is no point in me making an effort for the } \\
\text { environment if others do not do the same }\end{array}$ & $\square$ & $\square$ & $\square$ & & $\square$ \\
\hline $\begin{array}{l}\text { I agree with having regulatory constraints } \\
\text { (quotas, bans) put in place to protect the } \\
\text { environment, even if it limits my comfort }\end{array}$ & $\square$ & $\square$ & $\square$ & & $\square$ \\
\hline $\begin{array}{l}\text { Degrowth is necessary to face environmental } \\
\text { challenges }\end{array}$ & $\square$ & $\square$ & $\square$ & $\square$ \\
\hline $\begin{array}{l}\text { If things continue on their present course, we will } \\
\text { soon experience a major ecological catastrophe }\end{array}$ & $\square$ & $\square$ & $\square$ & $\square$ \\
\hline $\begin{array}{l}\text { If agree: This type of catastrophe could cause a } \\
\text { collapse of our societies: the basic needs (food, } \\
\text { energy, health, etc.) will no longer be assured for } \\
\text { the majority of the population }\end{array}$ & $\square$ & $\square$ & $\square$ & $\square$ \\
\hline
\end{tabular}

Information about your activity and your personal situation

Let's finish with a few questions about your activity in the research world and your personal situation. 
58. Are you involved in one or more research projects with dedicated funding (i.e. other than your institution's own funds)? (Several answers possible.)

\begin{tabular}{|l|r|r|r|}
\hline & Yes, as a member & Yes, as (co-)lead & No \\
\hline National Research Agency (ANR) & $\square$ & $\square$ & $\square$ \\
\hline Other French public funding & $\square$ & $\square$ & $\square$ \\
\hline $\begin{array}{l}\text { European funding (European Research } \\
\text { Council (ERC), H2020, etc.) }\end{array}$ & $\square$ & $\square$ & $\square$ \\
\hline Other international public funding & $\square$ & $\square$ & $\square$ \\
\hline Private funding (including private foundation) & $\square$ & $\square$ & $\square$ \\
\hline
\end{tabular}

59. Your relationship to the international scene. Whether you are French or foreign, the questions concern you as they are: for example, whether you are French or Italian, if you grew up in Italy, answer that you did your schooling outside France.

\begin{tabular}{|l|l|l|}
\hline & Yes & No \\
\hline Is your current main job located outside of France? & $\square$ & $\square$ \\
\hline Were you born in a foreign country? & $\square$ & $\square$ \\
\hline Do you have a foreign nationality (including dual nationality)? & $\square$ & $\square$ \\
\hline Did you spend at least one year of your primary or secondary education outside France? & $\square$ & $\square$ \\
\hline Have you studied (higher education) for at least three months outside France? & $\square$ & $\square$ \\
\hline Have you done one or more postdocs outside France?* & $\square$ & $\square$ \\
\hline $\begin{array}{l}\text { Have you worked (in teaching and/or research but not as a postdoc) for at least three } \\
\text { months outside France? }\end{array}$ & $\square$ & $\square$ \\
\hline Are you currently involved in an international research program?* & $\square$ \\
\hline Are you actively involved in a non-French or international professional association? & $\square$ & $\square$ \\
\hline
\end{tabular}

60. Since 2017 inclusive, approximately how many articles have you published (as an author or co-author) in peer-reviewed journals?*

_ _ items 
61. If $>0$ : Of these articles, approximately how many were published in English?

-- items

62. If researcher or other/NR: Do you know approximately your h-index?*

$\square$ Yes $\square$ No $\square$ Not concerned $\square$ I am not sure what the h-index is

63. If yes: Can you indicate the approximate value of your $\mathrm{h}$-index?

64. Do you hold a PhD thesis? $\square$ Yes $\square$ No

65. If yes: In what year did you defend it?

66. Are you at a point in your career where you are seeking promotion, recruitment or tenure?

$\square$ Yes $\square$ No

67. Do you feel like you are...

$\square$ Very well paid $\quad \square$ Well paid $\square$ Fairly paid $\square$ Poorly paid $\square$ Very poorly paid

68. If Civil servant/Permanent contract/Fixed-term contract/Self-employed: Are you currently employed full-time? $\square$ Yes $\quad \square$ No

69. If no: What is your work time share?
$\square 90 \%$
$80 \%$
$70 \%$
$60 \%$
$50 \%$ or less

70. In the last 3 years, have you interrupted your research activity (due to maternity leave, sick leave, layoff) for more than 3 months?*

$\square$ Yes $\quad \square$ No

71. Do you live in a couple? $\square$ Yes $\square$ No

72. How many children do you have?

73. If $>0$ : What is the age of the youngest? _ _ years 
74. What is the highest degree held by your parents?

\begin{tabular}{|l|l|l|}
\hline & Mother & Father \\
\hline No diploma & $\square$ & $\square$ \\
\hline Lower secondary & $\square$ & $\square$ \\
\hline Upper secondary & $\square$ & $\square$ \\
\hline Short tertiary (Bachelor or less) & $\square$ & $\square$ \\
\hline Long tertiary (Master's, etc.) & $\square$ & $\square$ \\
\hline Doctorate & $\square$ & $\square$ \\
\hline Don't know & $\square$ & $\square$ \\
\hline
\end{tabular}

75. When you were 18, what was your parents' employment status?

\begin{tabular}{|l|l|l|}
\hline & Mother & Father \\
\hline Civil servant or public sector employee & $\square$ & $\square$ \\
\hline Private sector employee & $\square$ & $\square$ \\
\hline Self-employed & $\square$ & $\square$ \\
\hline Unemployed & $\square$ & $\square$ \\
\hline Inactive or retired & $\square$ & $\square$ \\
\hline Deceased & $\square$ & $\square$ \\
\hline Don't know & $\square$ & $\square$ \\
\hline
\end{tabular}

The next two questions will allow us to calculate the size of the agglomeration, the type of municipality (rural/urban) and the distance between your place of residence and your place of work. You are free not to answer if you wish. We will destroy the information concerning the exact commune within one year.

Please indicate "Foreign" for municipalities located outside of France.

76. What is your place of residence?

77. What is the municipality where your workplace is located?

$----$ 
78. If you add up all the sources of income in your household, can you give the net monthly income after tax for your household in 2019? Take into account all the money coming in from everyone in your household: wages and professional income, pensions, various allowances, any proceeds from property or financial investments, etc.

Less than 1,500 euros per month

From 1,500 to 2,499 euros per month

From 2,500 to 3,499 euros per month

From 3,500 to 4,499 euros per month

From 4,500 to 5,999 euros per month

From 6,000 to 7,999 euros per month

From 8,000 to 9,999 euros per month

From 10,000 to 15,000 euros per month

Over 15,000 per month

I do not wish to answer

I don't know

79. Would you agree to be contacted by a researcher in a few months or more to answer further questions on the topics covered in this questionnaire? Giving your consent does not commit you to anything, you will simply receive an invitation to respond. In order to preserve the confidentiality of your answers, your address will be recorded in a separate file and for this purpose only.

$\square$ I disagree to be contacted again $\square$ I agree to be contacted again at the following email address:

Please enter here any comments you may have:

Let's finish with a little quiz! Can you estimate the greenhouse gas emissions of different professional practices? The correct answers will be given to you right after you fill it in.

80. $\square$ I take the quiz $\square$ I decline the quiz

81. If Quiz. In your opinion, what level of emissions per capita should the planet reach in 2030 to limit warming to $+1.5^{\circ} \mathrm{C}$ in 2100 ? For your information, greenhouse gas emissions per capita on the planet are currently 7 tons of $\mathrm{CO}_{2}$ equivalent per year, and the average emission of a French is 11 tons (carbon footprint). tonnes of $\mathrm{CO}_{2}$ 
82. If Quiz. How much greenhouse gas emissions (in $\mathrm{kg}$ of $\mathrm{CO}_{2}$ equivalent) do the following actions represent (knowing that the carbon footprint of a French is on average $30 \mathrm{~kg}$ per day)? Indicate the value that you think is closest.

\begin{tabular}{|l|l|l|l|l|l|l|l|l|l|l|l|l|l|}
\hline & $\begin{array}{l}10 \\
\mathrm{~g}\end{array}$ & $\begin{array}{l}100 \\
\mathrm{~g}\end{array}$ & $\begin{array}{l}1 \\
\mathrm{~kg}\end{array}$ & $\begin{array}{l}5 \\
\mathrm{~kg}\end{array}$ & $\begin{array}{l}25 \\
\mathrm{~kg}\end{array}$ & $\begin{array}{l}50 \\
\mathrm{~kg}\end{array}$ & $\begin{array}{l}100 \\
\mathrm{~kg}\end{array}$ & $\begin{array}{l}250 \\
\mathrm{~kg}\end{array}$ & $\begin{array}{l}500 \\
\mathrm{~kg}\end{array}$ & $\begin{array}{l}100 \\
0 \\
\mathrm{~kg}\end{array}$ & $\begin{array}{l}200 \\
0 \\
\mathrm{~kg}\end{array}$ & $\begin{array}{l}300 \\
0 \\
\mathrm{~kg}\end{array}$ & $\begin{array}{l}500 \\
0 \\
\mathrm{~kg}\end{array}$ \\
\hline $\begin{array}{l}\text { Drive } 50 \mathrm{~km} \text { to and from } \\
\text { work for a year (about } \\
12,000 \mathrm{~km} \text { ) }\end{array}$ & $\square$ & $\square$ & $\square$ & $\square$ & $\square$ & $\square$ & $\square$ & $\square$ & $\square$ & $\square$ & $\square$ & $\square$ & $\square$ \\
\hline $\begin{array}{l}\text { Fly from Paris to New York } \\
\text { and back (about 12,000 km) }\end{array}$ & $\square$ & $\square$ & $\square$ & $\square$ & $\square$ & $\square$ & $\square$ & $\square$ & $\square$ & $\square$ & $\square$ & $\square$ & $\square$ \\
\hline $\begin{array}{l}\text { Travel from Paris to } \\
\text { Marseilles and back by } \\
\text { high-speed train }\end{array}$ & $\square$ & $\square$ & $\square$ & $\square$ & $\square$ & $\square$ & $\square$ & $\square$ & $\square$ & $\square$ & $\square$ & $\square$ & $\square$ \\
\hline Build a new laptop & $\square$ & $\square$ & $\square$ & $\square$ & $\square$ & $\square$ & $\square$ & $\square$ & $\square$ & $\square$ & $\square$ & $\square$ & $\square$ \\
\hline $\begin{array}{l}\text { Make 3 hours of } \\
\text { videoconference with your } \\
\text { computer (for one person) }\end{array}$ & $\square$ & $\square$ & $\square$ & $\square$ & $\square$ & $\square$ & $\square$ & $\square$ & $\square$ & $\square$ & $\square$ & $\square$ & $\square$ \\
\hline $\begin{array}{l}\text { Print a 200 page thesis in 10 } \\
\text { copies, double-sided }\end{array}$ & $\square$ & $\square$ & $\square$ & $\square$ & $\square$ & $\square$ & $\square$ & $\square$ & $\square$ & $\square$ & $\square$ & $\square$ & $\square$ \\
\hline Produce a 150 g beef steak & $\square$ & $\square$ & $\square$ & $\square$ & $\square$ & $\square$ & $\square$ & $\square$ & $\square$ & $\square$ & $\square$ & $\square$ & $\square$ \\
\hline
\end{tabular}

Thank you for your participation in this survey. We greatly appreciate your time.

If you want to know more about the Labos 1.5 collective, please visit our website http://labos 1 point5.org. Feel free to subscribe to our newsletter or to get involved in our activities.

Quiz answers :

\begin{tabular}{|l|l|}
\hline & Weight in kilograms of $\mathrm{CO}_{2}$ \\
\hline $\begin{array}{l}\text { Global per capita } \mathrm{CO}_{2} \text { emissions in } 2030 \text { to limit } \\
\text { warming to }+1.5^{\circ} \mathrm{C}\end{array}$ & $\begin{array}{l}3 \mathrm{t} \text { according to the IPCC and the UN (25 Gt in total for a } \\
\text { projection of } 8.5 \text { billion inhabitants), i.e. a reduction of } 55 \%\end{array}$ \\
\hline
\end{tabular}




\begin{tabular}{|c|c|}
\hline & $\begin{array}{l}\text { for the current average emissions per inhabitant of the } \\
\text { planet, or } 75 \% \text { for the carbon footprint of a French. }\end{array}$ \\
\hline $\begin{array}{l}\text { Drive } 50 \mathrm{~km} \text { to and from work for a year (about } \\
12,000 \mathrm{~km} \text { ) }\end{array}$ & $3.1 \mathrm{t}(0.259 \mathrm{~kg} / \mathrm{km} * 12,000 \mathrm{~km}$ according to ADEME) \\
\hline $\begin{array}{l}\text { Fly from Paris to New York and back (about } \\
12,000 \mathrm{~km} \text { ) }\end{array}$ & $\begin{array}{l}1 \mathrm{t} \text { according to ADEME without taking into account the } \\
\text { vapour trails, double with }\end{array}$ \\
\hline $\begin{array}{l}\text { Travel from Paris to Marseilles and back by } \\
\text { high-speed train }(1600 \mathrm{~km})\end{array}$ & $\begin{array}{l}3.2 \mathrm{~kg} \text { according to Oui.sncf }(1.9 \mathrm{~g} / \mathrm{km} \text { for } 1600 \mathrm{~km} \text { ) and } \\
\text { between } 2.7 \text { and } 5.9 \mathrm{~kg} \text { according to ADEME (from } 1.7 \\
\mathrm{~g} / \mathrm{km} \text { to } 3.7 \mathrm{~g} / \mathrm{km} \text { ) }\end{array}$ \\
\hline Build a new laptop & $250 \mathrm{~kg}$ (210 kg for Dell laptop according to Ecoinfo) \\
\hline $\begin{array}{l}\text { Do } 3 \text { hours of video conferencing (for one } \\
\text { person) }\end{array}$ & $\begin{array}{l}\text { Precise and reliable estimates not available. } \\
60 \mathrm{~g} \text { per hour based on a quick estimate using } \\
\text { Carbonalyser tables (not including material manufacturing) } \\
4.5 \mathrm{~kg} \text { according to a simplified calculation of the EPFL: } \\
\text { about half for the amortization of the dedicated equipment, } \\
\text { and half for the electricity produced according to the } \\
\text { European mix; thus much less in France if we exclude the } \\
\text { equipment. }\end{array}$ \\
\hline $\begin{array}{l}\text { Print a } 200 \text { page thesis in } 10 \text { copies, } \\
\text { double-sided }\end{array}$ & $4.58 \mathrm{~kg}$ (for paper only) according to ADEME \\
\hline Produce a $150 \mathrm{~g}$ beef steak & 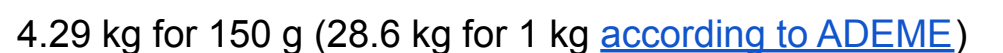 \\
\hline
\end{tabular}




\section{S4 Appendix. French statuses and their English translations}

Senior researcher: Directeur-rice de recherche

Full professor: Professeur·e

Tenured researcher: Chargé·e de recherche

Associate professor: Maître·sse de conférences

Research engineer: Ingénieur·e de recherche

Research support engineer: Ingénieur·e d'études

Engineer assistant: Assistant·e ingénieur·e

Technician: Technicien·e

Postdoctoral researcher: Post-doc

Adjunct lecturer: Attaché·e temporaire d'enseignement et de recherche (ATER)

Fully funded PhD student: Doctorant.e contractuel.le

Research assistant/Project manager: Chargé.e d'études/de mission

Technical assistant: Adjoint.e technique 